
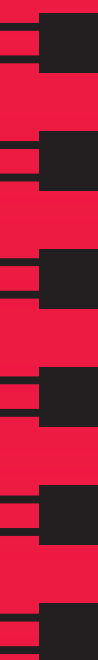

Gabriela Mafud

EXPERIÊNCIAS DE VIDA, FORMAÇÃO E ATUAÇÃO DE PEDAGOGAS: ARTE/VIDA EM DOIS ATOS
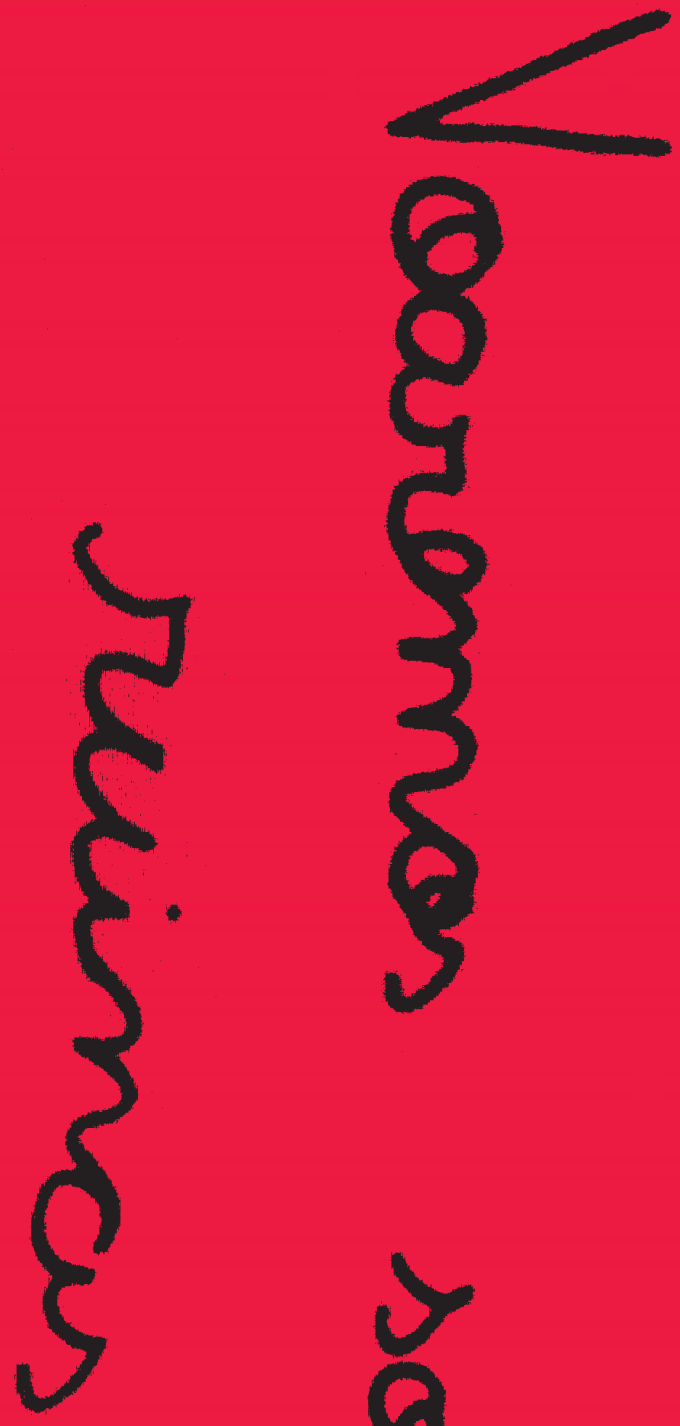

São Paulo 2019
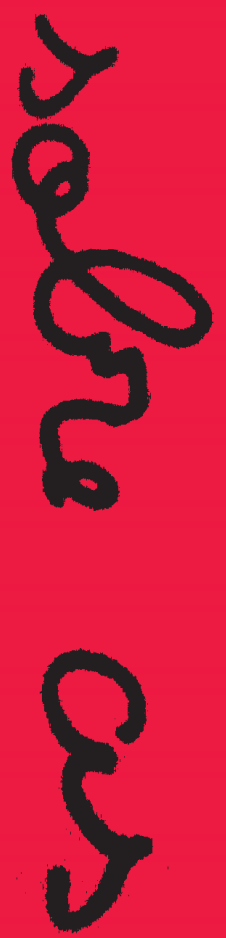
Universidade de São Paulo

Escola de Comunicações e Artes

Área de Concentração: Teoria, Ensino e Aprendizagem da Arte

Gabriela Mafud

\section{EXPERIÊNCIAS DE VIDA, FORMAÇÃO E ATUAÇÃO DE PEDAGOGAS: ARTENIDA EM DOIS ATOS}




\section{EXPERIÊNCIAS DE VIDA, FORMAÇÃO E ATUAÇÃO DE PEDAGOGAS: \\ ARTE/VIDA EM DOIS ATOS}

Dissertação apresentada ao Programa de Pós-Graduação em Artes Visuais da Escola de Comunicações e Artes ḑão em Artes Visuais da Escola de Comunicaçóoes e Artes da Universidade de São Paulo, como exigência parcial para obtenção do título de mestre em Artes, na linha de
pesquisa Teoria, Ensino e Aprendizagem da Arte, sob orientação da Profa. Dra. Sumaya Mattar. 
Autorizo a reprodução e divulgação total ou parcial deste trabalho, por qualquer meio convencional ou eletrônico, para fins de estudo e pesquisa, desde que citada a fonte.

Mafud, Gabriela

Experiencias de vida, formação e atuação de pedagogas:

Arte/Vida em dois atos: Arte/Vida em dois atos / Gabriela

Mafud ; orientadora, Sumaya Mattar. -- São Paulo, 2019.

147 p.: il.

Dissertação (Mestrado) - Programa de Pós-Graduação em Artes Visuais - Escola de Comunicações e Artes / Universidade de São Paulo.

Bibliografia

Versão original

1. Arte e Pedagogia 2. Arte/Educação 3. Formação de pedagogia em Arte 4. Autobiografia 5. Práticas de Si I. Mattar, Sumaya II. Título.

CDD 21.ed. - 700.7

Elaborado por Sarah Lorenzon Ferreira - CRB-8/6888 
A todas as alunas e alunos que atravessam meu caminho durante esses anos de viagem pela arte e pela educação. Obrigada por me ensinarem a ser professora. 
À minha querida orientadora Profa. Dra. Sumaya Mattar, obrigada pela amizade, pelas provocações, parceria e fundamentalmente por me jogar no abismo e, assim, me fortalecer como pesquisadora. Obrigada também por incentivar em nossas pesquisas um ato político!

Às queridas Profas. Dras. Ana Angélica Albano e Betania Libano por gentilmente terem aceitado participar da banca de qualificação e me trazerem ótimas contribuições.

Às colegas do GMEPAE (Grupo de Multidisciplinar de Estudos e Pesquisas em Arte/Educação) da ECA/USP em especial: Clarissa Suzuki, Julia Bortoloto, Vinicius Bonfinacio, Francisca Carolina, Guilherme Nakashato, Maria Pinheiro, Leandro Oliveira, Paula Davis e Alberto Roiphe. Obrigada por todo apoio a essa pesquisa e por compartilharem comigo a luta pela educação!

Às queridíssimas pedagogas que são parte fundamental desta dissertação: Priscila Brito, obrigada pela doce caminhada durante esses mais de 7 anos de parceria, compartilhando pesquisas, viagens pelo conhecimento e pela educação!

Letícia Mello, obrigada por todos esses anos de parceira e (re)descobertas pelo ensino. Pelas trocas e afetos!

Carolina Hamburguer, obrigada pelas doces memórias, contribuições e pelas jornadas na luta política!

Bianca Bressan, obrigada por compartilhar comigo sua história, pesquisa e atuação na escola!

Mais uma vez, obrigada por terem aceitado compartilhar suas experiências e memórias para a construção desta dissertação.

Ao meu amante/camarada de vida/obra Diego Arvate por todo incentivo, pelas leituras afetivas da pesquisa, pelo acolhimento e pela compressão ao longo desta jornada. Obrigada!

À amiga vida/obra Maíra Suzuki por fazer da nossa casinha um ambiente gostoso para o desenvolvimento da escrita.

À minha amiga e comadre de vida/obra Marcela Souza por diagramar minha dissertação e também fazer parte existencial de minha história.

Ao amigo de vida/obra Marcelo Maraninchi (Cadinho), pelas revisões, obrigada por toda curiosidade em conhecer meu trabalho, pelo carinho e pela troca!

Às minhas amigas e amigos de vida/obra por compartilharem a vida e a arte comigo, me apoiando a todo tempo nesta viagem: Débora Oelsner Lopes, Amanda Carvalho, Isabela Mariotto, Marina Cano, Tiago Villa Mello (Joe), Anna Camargo, Júlia Burnier, Bruna Carvalho, Ana Luísa Ribeiro, Priscila Lourenção, Bruno Caetano, Gabriel Brigante, Pedro Fonseca, Francine Nunes, Fernanda Volp, Adriana Melo, Maria Fernanda Naufel, Bruna 
Soares, Ana Beatriz Moreira, João Camargo, Fabiana Cassarotti, Juliana Ito e Marcelo Pliger.

Ao Rafael Sertori pelas leituras do meu trabalho.

Aos meus afilhados amados, Heitor Feracin e Pedro Pliger por compartilharem comigo suas infâncias, trazerem tantas doçuras e (re)descobertas em minha vida.

Às colegas do Colégio São Domingos que tanto me apoiaram ao longo desses anos: Ana Carolina Medeiros, André Sousa, Cinthia Manzano, Gabriela Schien, Cintia Albiero, Maria Clara Ferreira, Leandro Cunha, Leandro Canhete, Rodrigo Pança, Júlio Brandão, Inessa Silva, Marina Senna e Aline Essu, Larissa Saito, Ana Motta, Suzana Moreira, Bia Alvares e Silvio Barini Pinto.

À querida Cecília Sanches e ao querido Paulo Sanches (ex-aluno) por terem me emprestado todo material de trajeto do Paulinho, ajudando a relembrar tantas aventuras expressadas no $1^{\circ}$ ato da dissertação.

Às queridas Ana Degenszajn e Cléo Degebszajn e ao Marcelo Schmiliver por compartilharem as fotografias da experiência teatral da Cléo quando éramos professora e aluna. Que lindo recordar essas memórias!

À tia Maria Zélia, ao tio Toninho, às primas Ana Carolina Feracin e Maria Eleonora Feracin; e ao primo Luís Felipe Feracin pelo cultivo do ambiente docente em nossa família.

Por fim, e especialmente, à minha mãe Fátima Mafud e ao meu pai Anísio Feracin, obrigada pela existência. Às minhas queridas irmãs Natália Mafud e Barbara Mafud por compartilharem a vida e o ensino comigo.
(...) O tempo é escasso -

Primeiro

é preciso

para cantá-la transformar a vida, em seguida.

\author{
E o sol, por fim: \\ Somos amigos \\ para sempre, eu de você, \\ você de mim. \\ Vamos, poeta \\ cantar, \\ no lixo cinza do universo \\ Eu verterei o meu sol \\ e você o seu \\ com seus versos." \\ O muro das sombras, \\ prisão das trevas, \\ desaba sob o obus \\ dos nossos sóis de duas bocas. \\ Confusão de poesia e luz, \\ chamas por toda parte. \\ Se o sol se cansa \\ e a noite lenta \\ quer ir para cama, \\ marmota sonolenta \\ eu, de repente, \\ inflamo a minha flama \\ e o dia fulge novamente. \\ Brilhar para sempre \\ brilhar como um farol, \\ brilhar com brilho eterno \\ Gente é para brilhar \\ que tudo mais vá para o inferno \\ esse é o meu slogan
}

e o do sol.

Vladimir Maiakóvski

Todos os poemas e versos mencionados do poeta russo Vladimir Maiakóvski encontram-se no livro intitulado Maiakóvski traduzido e organizado por: CAMPOS, Augusto e Haldo e SCHNAIDERMAN Boris. Publicado pela editora Perspectiva, Sa 2003 
Esta dissertação apresenta uma reflexão sobre a relação dialógica existente entre a arte e a pedagogia. Para isso, parto da seguinte pergunta: como as experiências de vida e formação em arte contribuem para que pedagogas e pedagogos dialoguem, em suas práticas em sala de aula, com o campo da arte/educação?

Para que este diálogo fosse possível, mergulhei em minha própria experiência de formação, buscando compreender a importância da arte para a minha constituição como educadora. As reflexões são ampliadas no diálogo com quatro pedagogas que também procuram vivenciar experiências em arte como possibilidades para suas práticas educativas. Finalmente, investigo as experiências de vida utilizando uma abordagem autobiográfica, como fonte de conhecimento das relações entre arte e pedagogia.

Palavras Chave: Arte e pedagogia, arte/educação, formação de pedagogas e pedagogos, autobiografia e práticas de si.

\section{ABSTRAC}

This thesis reflects on the dialogical relationship between art and pedagogy. To do so, I begin by posing the following question: How do life experiences and training in art contribute to the dialogue between educators - within their classroom practices_ and the field of "art/education"?

In order to make this dialogue possible, I immersed myself in my own lifelong formation experience, seeking to understand the importance of art for my constitution as an educator. The reflections are broadened in a dialogue with four educators who also try to live experiences in art as possibilities for their educational practices. Finally, I investigate life experiences using an autobiographical approach as a source of knowledge of the relationships between art and pedagogy.

Keywords: Art and pedagogy, "art/education", teacher training, autobiography and self-practices. 
Figura 1. Carta presente, 2018

Figura 2. Encenação: Vladimir no país da gramática, 2009

Figura 3. Lançamento do Manifesto Coro de Carcarás, 2009

Figura 4. Encenação: O Percevejo, 2010

Figura 5. Teatro de Arena - última atuação no Coro de Carcarás, 201138

Figura 6. Desenho da semente de feijão, 2014

Figura 7. Desenho de observação do jardim, 2014

Figura 8. Crianças no ateliê de desenho, 2014

Figura 9. Escrita com imagem, 2014

Figura 10. Crianças no ateliê de argila, 2014

Figura 11. Cena: Coro Ateniense, 2014

Figura 12. Cena: Ritual Parsifae, 2014

Figura 13. Escrita Teatro de Dioniso, 2014

Figura 14. Criação de imagens arquitetônicas de teatros, 2014

Figura 15. Situação problema e deuses gregos, 2014

Figura 16. Ateliê de criação de objetos tridimensionais I, 2014

Figura 17. Ateliê de criação de objetos tridimensionais II, 2014

Figura 18. Crianças em cena I, 2014

Figura 19. Crianças em cena II, 2014

Figura 20. Crianças na relação com espaços de acontecimentos, 201862

Figura 21. Aula de teatro, 2018

Figura 22. Ateliê com restos de argila: criação de cores, 2019

Figura 23. Apolo, 2018

Figura 24. Projeção de sombras, 2018

Figura 25. De corpo inteiro no Planeta Isopor, 2018

Figura 26. Desenho sobre a pesquisa do Universo, 2018

$\begin{array}{ll}\text { Figura 27. Fresta I } & 117\end{array}$

Figura 28. Fresta II

Figura 29. Bilhete voaremos sobre as ruinas e teatro

será nossas asas, 2018
4

$1^{\circ}$ Ato

As experiências formativas

23

1.1. Os deslocamentos e a criação da artista professora

1.2. O que foi em mim a Universidade

e seus espaços educativos

$$
\begin{aligned}
& \text { 1.2.1. O teatro me ensinou a vida } \\
& \text { 1.2.2. A sala de aula me fez professora }
\end{aligned}
$$

1.3. Uma experiência para narrar

1.3. O tempo e suas potências

$2^{\circ}$ Ato

As experiências de vida e formação construindo trajetos para a formação de si

2.2. Carolina e as utopias no caminho da construção de si

2.2.1. Um entender do lugar da pedagoga

e seu papel de transformação

2.2.2. A relação com a arte vem

muito da minha infância

2.2.3. Vê-las descobrindo e criando é uma sensação

de muito prazer

2.2.4. Quando estou com as crianças, a própria energia

delas me contamina

2.2.5. Tão triste ver criança dizendo que não sabe desenhar

2.3. Priscila: a cultura da infância como potência

de sua prática docente

2.3.1. Quero ser o fogo

2.3.2. Um desenho me chamou muito a atenção

2.3.3. Criança também faz arte

2.3.4. Você vai de corpo inteiro, porque é assim que as crianças criam

2.3.5. A criança é essencialmente um ser sensível

à procura de expressão

2.4. Letícia: as andanças, mudanças de rota, fugas e prática docente na construção de si

2.4.1. Pela prática eu me apaixonei 
2.4.2. Um caminho para o campo da arte foi a escola

2.4.3. O campo da Arte é onde me pega

e está na sala de aula o tempo todo

2.4.3. Desenho das crianças, é uma coisa que me mobiliza, que sinto falta de trabalhar

2.4.4. O desenho da figura humana é super importante

2.4.5. Um lugar para fugir da escola

2.4.6. A minha limitação esbarra exatamente

na minha falta de formação em arte

2.5. Bianca: das aulas de dança ao encontro com a docência

2.5.1. Foram muitas experiências e vivências que não posso deixar de reconhecer

2.5.3. Se a gente não sente aquilo na pele, não tem como passar essa experiência, a gente não tem como proporcioná-la às crianças

2.5.4. Essa coisa de propor só com pé, uma vez que eu poderia ter proposto com corpo inteiro

2.6. Das singularidades para os encontros de uma prática educativa mergulhada na arte/educação 
PRÓLOGO 
Assim como no teatro, antes dos diálogos começarem, apresenta-se o prólogo. Ele introduz o início dos acontecimentos de uma peça e apresenta os personagens, os cenários, os acasos, o tempo e o espaço. Dessa maneira, escolho nomear como tal a introdução de minha dissertação. Na mesma direção, nomeio os dois capítulos como atos. São eles as divisões de todo desenvolvimento cênico, agregam o que foi introduzido e o transformam em ações e movimentos. Seguindo esse fluxo, escolho nomear como epílogo as conclusões, como nas peças teatrais onde ele traz os desfechos dos acontecimentos narrados.

Não se trata aqui do desenvolvimento de uma dramaturgia teatral longe disso: esta pesquisa aborda reflexões a respeito da arte e da vida na construção formativa de pedagogas e pedagogos que escolheram a sala de aula, portanto, a escola como possibilidade de pesquisa e trabaIho. Neste sentido, não vamos desenvolver uma narrativa clássica teatral. Apenas tomo emprestadas tais nomenclaturas na tentativa de aproximar o teatro enquanto arte fundante de minha trajetória. Esta pesquisa narra justamente o percurso (trans)formador de uma atriz-professora. O teatro está corporificado em minha memória, em minha história, em meu corpo e em minha ação perante a vida. Presentemente, arte e vida caminham juntas e são relações indissociáveis. A educação é parte integrante de minha constituição humana. Atuo como professora das infâncias há mais de dez anos.

Escrevo os acontecimentos que vivenciei na perspectiva de extrair conhecimento e reflexões acerca do meu percurso formativo, inserindo-o no contexto histórico que corresponde do início dos anos 2000 até a atualidade. Procuro compreender a relação dialógica que afirmo existir entre arte e pedagogia. Para estabelecer um diálogo, porque desta maneira comungo a vida, entrevistei quatro pedagogas no período de novembro a dezembro de 2018. Elas, como eu, estabelecem diálogos em sala de aula com o campo de conhecimento acerca da arte/educação.

O coração da pesquisa move-se por compreender como as experiências de vida e formação em arte contribuem para que pedagogas e pedagogos dialoguem, em suas práticas em sala de aula, com o campo da arte/educação. São caminhos que nos levam a entender por que a relação entre pedagogia e arte/educação é tão presente em diversas discussões, 
formações e práticas educativas. Em um lugar comum, o desejo pela arte campo aberto de infinitas possibilidades, que faz parte da construção de educadoras e educadores em uma relação íntima com o nosso tempo histórico.

Para construir esse percurso, escolho o relato autobiográfico como abordagem metodológica de minha pesquisa. As provocações e a construção do percurso de pesquisa feitas pela minha orientadora, Profa. Dra. Sumaya Mattar, me levaram a concluir que os relatos autobiográficos me trariam suporte para sustentar as indagações que desenvolvo nesta escrita.

No $1^{\circ}$ ato vou tecendo narrativas extraídas de minhas memórias, os caminhos que foram me construindo, a sala de aula como elemento fundamental da minha formação e o encontro com o teatro. Transformei esse material em relatos de experiências e deles desenhei o que chamo de cartografias de si'. Tal desenvolvimento me levou a lugares que me ajudaram a captar gestos e trajetos formativos. Eles compõem tanto minha construção histórica, quanto a maneira como atuo em sala de aula. Neste momento, abro diálogo com o que Sumaya Mattar (2018) exprime sobre o trabalho a partir da escrita de memória e dos relatos de experiências:

Necessitamos contar nossas histórias a alguém. O relato primordial é aquele que pode ser feito a outras pessoas, seja pela palavra falada, seja pela palavra escrita. Nossas histórias ganham relevância quando as relatamos. Através delas, o que vivemos ganha uma dimensão social, obtém testemunhas e faz com que outras pessoas ampliem sua experiência através da nossa palavra. (MATTAR, p. 259)

Tecendo as histórias que escolhi contar às outras pessoas como uma possibilidade de ampliar o debate acerca da arte na pedagogia, para o $2^{\circ}$ ato realizei entrevistas separadamente com quatro pedagogas que, ao longo desses anos de trabalho e estudo na cidade de São Paulo, cruzaram meu caminho. Elas formaram-se em pedagogia na mesma universidade, trabalham em escolas e atuam como professoras das infâncias, na Educação

1. Os termos cartografia de si e/ou construção de si são pesquisados por Sumaya Mattar e encontram-se em suas diversas produções dissertação, tese e atigos. A pesquisa dora desenvolve a ideia de que os relatos autobiográficos fazem parte de un sistema formativo de cartografias de os relatos autobiográncos fazem parte de um sistema e criação a partir das experiências e percursos formativos de professoras e professores. Assim, os relatos autobiográficos e a construção de cartografias revelam os caminhos e andanças pelo campo da Arte e Educação. Trata-se de um pensamento a partir do que Michel Foucault nos descreve a respeito das práticas de cuidado da cultura greco-romana e recomendadas pelos estóicos. Estes elaboraram uma série de exercícios que levavam aos processos de cuidados de si, sendo a escrita uma das maneiras de se chegar a essa reflexão: "Os cuidados de si eram uma maneira de o sujeito [ ] se elaborar, se transformar e atingir um certo modo de ser". (FOUCAUIT, 2004, P
Infantil e Ensino Fundamental I. Buscam para suas construções e formações o campo da arte como elemento-chave para o desenvolvimento de suas práticas educativas.

Nesse capítulo trabalhei com o material das entrevistas, desenvolvendo o material a partir da ideia de memória oral a partir das reflexões de Ecléa Bosi:

A memória oral, longe da unilateralidade para a qual tendem certas instituições, faz intervir pontos de vista contraditórios pelo menos distintos entre eles, e aí se encontra a sua maior riqueza. Ela não pode atingir uma teoria da história nem pretender tal fato: ela ilustra o que chamamos hoje a História das Mentalidades, a História das Sensibilidades. $(2013$, p. 15)

Procurando uma História das Sensibilidades, lugares em que emergiram contradições e encontros, criei para cada entrevistada um relato de experiência a partir de suas memórias. Transformei-os em cartografias, evidenciando suas singularidades. Aí está a grandeza do material, cada professora, a sua maneira, a sua história e desejo, criou caminhos e possibilidades entendendo o campo da arte como possibilidade de ampliação de seus trabalhos educativos com as crianças. Em seguida fui compreendendo o que conectava uma a outra. Procurei extrair de suas questões e reflexões uma fonte de conhecimento e possibilidade de trabalhar na sala de aula os campos de conhecimento da arte/educação, relacionando-os às demais linguagens. Por isso, trago a voz de pedagogas que estão totalmente conectadas à escola, à sala de aula, tanto no ensino público quanto no ensino privado.

Desenvolvo, a partir disso, a dissertação da seguinte maneira: $1^{\circ}$ ato: As experiências formativas, relatando e refletindo meu percurso na formação inicial; as relações que construí e estabeleci nas Universidades que estudei; a atuação em grupos de teatro de rua; a chegada à escola; a transformação de professora a partir do diálogo que estabeleço com minhas alunas e alunos. Extraio, portanto, de minhas andanças (trans)formativas elemento que me levam a refletir como os processos de formação na construção da subjetividade são múltiplos e que, muitas vezes, eles não acontecem apenas em sala de aula ou em espaços educativos. Eles aparecem também na busca por vivenciarmos novas situações que nos são colocadas perante a vida. Reflito, com o que foi exposto, sobre minha prática docente e a maneira que fui encontrando para relacionar os campos da arte e da pedagogia na sala de aula.

No $2^{\circ}$ ato, As experiências de vida e formação construindo trajetos para a formação de si, estabeleço diálogo com quatro pedagogas que cruzaram meus caminhos nesses mais de dez anos de viagem pelos campos da arte e da educação. Bianca Bressan, Carolina Hamburguer, Leticia Oliveira Mello e Priscila Fernanda Brito formaram-se em Pedagogia pela Faculdade 
de Educação da Universidade de São Paulo, nas primeiras décadas dos anos 2000. Seus percursos formativos são construídos de maneira singular. No entanto, há em comum nas suas práticas educativas um convite a experiências que dialogam com a arte e a educação. Dessa maneira, seus relatos foram me levando a lugares que me ajudaram a compreender a maneira como experienciam a vida, a relação com a arte e como todo esse processo mostra-se forte na sala de aula e na relação com suas alunas e alunos.

Marie-Cristine Josso reflete sobre como as narrativas de experiências são instrumentos potentes para se pensar a maneira como estruturamos nossa vida e nosso trabalho:

O que caracteriza essencialmente as posições existenciais de vida, estando todas elas misturadas, é a procura da felicidade. As narrativas de vida contam itinerários ao longo dos quais os autores qualificam as suas experiências de vida classificando-as, quer em períodos felizes, quer em períodos psíquica ou fisicamente dolorosos. A vida humana apresenta-se pois de forma ininterrupta nesta dialética do bem-estar e do sofrimento. É no incessante retorno deste "jogo de ioiô" que emerge uma posição existencial mais ou menos ativa para tentar uma saída, se ela for pensada como possível, e para ir à descoberta de uma nova maneira de "governar" a própria existência, nova maneira essa considerada a melhor para amortecer os impactos, muitas vezes perturbadores, dessa dialética." (JOSSO, 2004, p. 88 e 89)

Ao estabelecer diálogos com as pedagogas nas entrevistas, somando-os à reflexão a partir de meu relato, encontrei uma característica viajante: a busca de novos itinerários, como salienta Josso. Ao depararmos com questões postas pela vida, no vai e vem em que os trajetos nos colocam, muitas pessoas procuram construir-se dessa maneira, aceitando as transformações, os desejos e a possibilidade de (re)existir. Refletir sobre esse aspecto como característica da construção subjetiva de professoras e professores, em tempos atuais, é fundamental.

Assim, colocamo-nos em movimento com o tempo presente, somos capazes de nos observarmos de forma crítica e construtiva. Nossa história não é algo isolado dos acontecimentos postos socialmente, pelo contrário. Estamos inseridas em um processo histórico, onde a formação, a atuação em sala de aula e a busca de experiências em arte dizem muito sobre nossa construção temporal. Além disso, atentas à voz de uma classe bastante massacrada em nossa sociedade.

$1^{\circ}$ ATO

AS EXPERIÊNCIAS FORMATIVAS 
Gabs,

Nessa
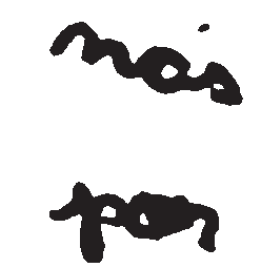

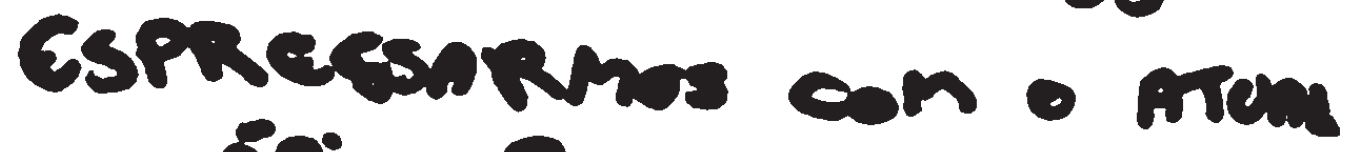
cenpirits Pourice.
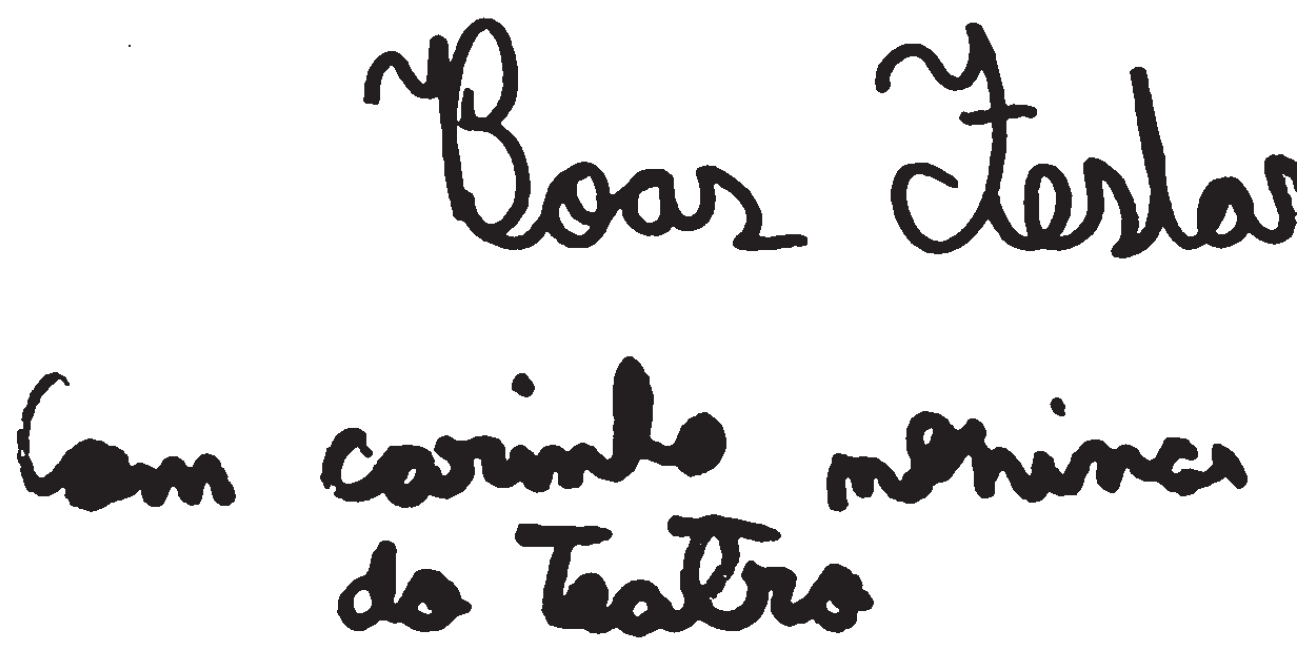

Figura 1. Ganhei essa carta de minhas alunas no final de 2018. Durante todo o ano, as meninas criaram cenas teatrais dialogando com os fatos políticos: greve dos caminhoneiros, paralisação de professoras e professores da rede privada de São Paulo e eleições.
1.1. OS DESLOCAMENTOS E A CRIAÇÃO DA ARTISTA PROFESSORA

"É engraçado a força que as coisas têm, quando elas precisam acontecer." Caetano Veloso

É engraçado como quase nunca esperamos os deslocamentos que a vida nos impõe. Caetano Veloso, ao falar sobre a interpretação de Maria Bethânia da música Carcará, canção tão marcante em meu encontro com o teatro, fala sobre a força que as coisas têm, quando elas precisam acontecer. Essa força me leva a refletir de que modo cheguei à minha escolha pelo curso de Pedagogia, a busca da arte em meus caminhos e toda narrativa que pretendo desenvolver neste primeiro ato. Escolho intitular como "Ato," pois assim acontecem as primeiras ações nas peças teatrais. A minha relação com o teatro ainda será revelada. Por hora, começo a contar como escolhi ser pedagoga. Era o ano de 2003, estava fazendo cursinho e, até julho, certa de que prestaria vestibular para o curso de História. Mas há desvios em nossos caminhos, somos impulsionados por forças desconhecidas, deslocando-nos para outros lugares que, curiosamente, ainda não havíamos acessado. Sobre caminhos, Jorge Larrosa nos diz que:

(...) não há um caminho traçado de antemão que bastasse segui-lo, sem desviar-se, para se chegar a ser o que se é. O itinerário que leva a um "si mesmo" está para ser inventado, de uma maneira sempre singular, e não se pode evitar nem as incertezas nem os desvios sinuosos. De outra parte, não há um eu real e escondido a ser descoberto. Atrás de um véu, há sempre outro véu; atrás de uma máscara, outra máscara; atrás de uma pele, outra pele. O eu que importa é aquele que existe sempre mais além daquele que se toma habitualmente pelo próprio eu: não está para ser descoberto, mas para ser inventado; não está para ser realizado, mas para ser conquistado; não está para ser explorado, mas para ser criado. (p. 9, 2013)

Estava seguindo meu itinerário, certa de um "si mesmo" a ser criado e, no entanto, como salienta Larrosa, ocorreu um desvio sinuoso, algo novo estava prestes a ser inventado e criado. Nas férias de inverno, acontecia anualmente a Semana Universitária Mocoquense (SUM). Até a primeira década deste século, era uma semana repleta de atividades culturais que movimentava bastante a cidade de Mococa, onde nasci e morei até o fim da adolescência. Aconteciam shows de bandas famosas, peças teatrais e eventos culturais durante as tardes no clube da cidade. Um colega que fazia parte da organização convidou-me para promover oficinas com crianças de escolas públicas. Fiquei animada com o convite, mas não tinha nenhuma experiência com o universo infantil. Junto com uma colega, pensamos em uma série de atividades envolvendo desenho, construção com sucatas,

24

25 
argila e pintura. Assim, promovemos as oficinas - mal podia imaginar que aquela semana transformaria decisivamente meus caminhos e que provocaria em mim uma nova forma de pensar e atuar no mundo. Foi a partir da observação das crianças produzindo visualmente que me encantei com o universo infantil. As expressões que nasciam com manuseio dos suportes e materiais oferecidos me chamavam muito a atenção. Do papel com o giz de cera, criam-se narrativas. $O$ desenho geralmente conta uma história e o boneco de argila era personagem de algum fragmento advindo daquele imaginário. As crianças criam possibilidades e capacidades de reinventar um mundo novo, paralelo e diferente ao mundo vivido. São, assim, narradoras de suas experiências, ora no desenho, ora na escultura e ora no brinquedo novo construído com os restos de sucatas.

Hoje, com mais de dez anos de docência, consigo compreender melhor por que a relação com esse universo foi tão fortemente marcante. Tive uma experiência escolar bastante traumática. Sempre fui uma criança, como todas, bastante criadora. Adorava desenhar e contar histórias com os meus desenhos. Sempre que me sentia entediada, procurava criar narrativas, personagens, gostava de brincar e teatralizar situações. Meus pais, buscando uma boa escolha para minha educação escolar, matricularam-me em um colégio tradicional e particular da cidade de Mococa. Até a antiga segunda série, estudava em uma escola municipal localizada em meu bairro. Tenho ótimas recordações daquele espaço, lembro-me que ia caminhando de casa até a escola; havia um jardim bem bonito na entrada, as professoras eram bastante afetivas e, até aquele período, nunca tinha vivenciado problemas escolares. Aos sete anos, no entanto, ao mudar de escola, vivenciei uma experiência bastante dura em minha constituição infantil.

Meus desenhos passaram a ser tachados, o erro e a falta foram marcas carregadas em meu cotidiano escolar. Minha maneira de expressar as descobertas não foram vistas sensivelmente; algumas delas, inclusive, eram caracterizadas de forma pejorativa. Minhas professoras tinham o hábito de expor algumas crianças perante o grupo e eu era uma delas. Isso me gerou muita dificuldade no relacionamento com os demais estudantes. Parecia-me que nada do que eu apresentava era suficientemente bom para o que a escola esperava. Na terceira série, esses problemas foram se intensificando. Meu rendimento escolar era péssimo, passei a somatizar no corpo o horror que vivia na escola; ficava muito doente, meus cabelos começaram a cair e lembro de ter dores horríveis na cabeça. Naquele ano, começaram as avaliações e ainda guardo algumas recordações; lembro-me de recebê-las marcadas com caneta vermelha e, às vezes, com o escrito de "insuficiente". Atualmente, como professora, consigo ter clareza do quão agressiva é uma marca dessa natureza em uma escrita infantil. Naquele momento, estava descobrindo, ao meu tempo, uma maneira de relacionar-me com o conhecimento escolar. Tinha acabado de ser alfabetizada e a escrita ainda era como um grande código a ser descoberto. Espera-se, a meu ver, que as professoras e professores estabeleçam diálogo com seus estudantes. Rabiscar uma escrita e marcá-la apontando somente os erros, não me parece ser uma tentativa de dialogar com o conhecimento. Pelo contrário, reforça apenas aquela tradicional característica de abordagem pedagógica que não reconhece a comunhão do saber, mas sim, o saber maior dos professores. Procurando o erro dos alunos, erram mais ainda, pois não encontram uma comunicação que os ajudem a avançar em suas pesquisas. Essa forma acaba sendo um processo opressor para o outro e para si mesmo.

Ao final daquele ano, fui reprovada, com uma marca muito ruim. Não tive nenhum acolhimento, e a sensação de que nada do que eu criava era bom, aos oito anos de idade, permaneceu por um tempo. Meus pais resolveram me mudar de escola novamente. Voltei, então, para a escola onde estudara anteriormente e, aos poucos, as coisas foram melhorando. Fiz terapia e construí um novo espaço para criar, para brincar, para desenhar e ser o que quisesse. Passei a frequentar um projeto de Arte oferecido pela prefeitura de Mococa chamado "Musiarte". Ele durou apenas um ano, mas foi fundamental naquele momento: as aulas de flauta, desenho e teatro me fortaleceram. Fui conseguindo voltar a me expressar de forma mais segura.

Hoje, percebo que a escolha pelo curso de Pedagogia deu-se pela força no (re)encontro com o universo infantil. Aqueles pequenos me ajudaram a me reconectar com algo pulsante produzido na infância; a potência criadora que todas as crianças têm em sua essência, independentemente da cultura em que estão inseridas. O que tolhe essa essência, essa natureza criadora, é justamente uma sociedade ausente de olhar sensível às singularidades. Como pode uma criança não realizar nada de bom? Esse pensamento só pode pertencer a uma análise mercadológica do ensino. Uma escola cuja metodologia de relação com o conhecimento é voltada para que as crianças passem a ser competitivas umas com as outras e não cooperativas. Uma escola que visa, desde a educação infantil, projetar nos estudantes a ideia do vestibular e do mercado de trabalho, massacrando as singularidades dos sujeitos envolvidos naquele espaço.

Acredito que a escola deve ser um espaço de possibilidades infinitas de criação e de procura pelo conhecimento. A criança realiza-se pela brincadeira, pela arte, pela criação de cultura, portanto. Evidentemente, existirão desafios importantes a serem superados, mas sempre há potência. Mais do que isso, um grande caminho a ser criado, inventado e reinventado. Mas como construir esse olhar na formação de professoras e professores? O que está acontecendo com os cursos de formação? O que falta em sua constituição para que as futuras pedagogas e pedagogos possam perceber a sensibilidade dos processos singulares de cada educando? Nesse sentido, considero fundamental a tarefa de problematizar o curso de Pedagogia e sua relação com o campo de conhecimento advindo de processos de experiências formativas a partir da Arte. Considero que esses processos podem ajudar a vislumbrar potencialidades mais sensíveis nas práticas das futuras pedagogas e pedagogos. 
O ambiente escolar, sobretudo a docência, sempre foram familiares em minha constituição humana. Minha tia Zélia, irmã do meu pai, é pedagoga aposentada. Na minha infância, ela lecionava em uma escola estadual e eu lembro perfeitamente bem de sua indignação com tudo aquilo. Passava bastante tempo em sua casa; recordo-me, até hoje, das pilhas de provas que ela tinha para corrigir - de maneira especial, pois era bastante afetiva. Gostava de ouvir tia Zélia falar sobre sua experiência escolar. Seu marido, o tio Toninho, também é educador e, até hoje, leciona como professor de Sociologia. Aquele universo era e é muito fundamental para mim, com os livros, os filmes, as árvores do jardim, as narrativas da experiência de viver como professora e professor, um espaço de muito acolhimento. Minhas primas, Ana Carolina, Maria Eleonora, e meu primo, Luís Felipe, também estudaram para se formarem professores. Este ambiente docente contaminou não apenas a mim mas, do mesmo modo, minhas irmãs. Natália, como eu, é pedagoga. Atualmente, é diretora de uma escola municipal na cidade de São José do Rio Pardo. Bárbara escolheu a Biologia como caminho inicial. Minha prima mais velha, Ana Carolina, cursou História na UNICAMP. Claramente, minha decisão primeira por cursar História estava vinculada a essa referência. Queria ser professora de todo jeito. Aquele desvio singular, no inverno de 2002, só me ajudou a restabelecer uma força muito visceral aqui dentro. Aquelas crianças, as primeiras, ajudaram-me a começar a encontrar a Gabriela criança e a ser capaz de ressignificar essa experiência, tornando-me pedagoga.

Naquele momento, meu interesse era buscar uma pedagogia que voltasse seu olhar à criação plástica das crianças, respeitando suas singularidades e suas expressões - a relação com o universo artístico e as infâncias eram elos que reverberaram e reverberam até os dias de hoje em minhas buscas como pedagoga.
1.2. O QUE FOI EM MIM A UNIVERSIDADE E SEUS ESPAÇOS EDUCATIVOS

Procurando encontrar um curso que me ajudasse a compreender o lugar da arte nas infâncias, recebo a notícia da aprovação no vestibular na UNESP, campus Araraquara, no início de 2003. Imaginava que encontraria aulas que me fizessem aproximar das linguagens artísticas na relação com o universo infantil. Aquela oficina ainda estava muito presente e queria realmente trabalhar nesse campo.

Durante o primeiro ano de graduação, as disciplinas não me despertaram grande entusiasmo, não encontrei o que estava procurando e sentia muita falta de estudar e pensar sobre a arte na escola. Por essa falta, as conversas embaixo das árvores do campus com meus amigos que cursavam Ciências Sociais pareciam-me mais interessantes.

Outro desvio, no entanto, apareceu. Uma aprendizagem bastante significativa durante a graduação não aconteceu na sala de aula propriamente dita. No final do primeiro ano do curso de Pedagogia, comecei a frequentar o grupo de estudos sobre Paulo Freire e decidi que, no ano seguinte, tentaria bolsa para me tornar professora do PEJA (Projeto de Extensão de Alfabetização de Jovens e Adultos); isso aconteceu no segundo ano de graduação. Meus alunos eram bem mais velhos que eu, lembro-me de seu Antônio, um senhor de mais de 70 anos que nunca havia frequentado a escola. Passara toda a vida trabalhando com a terra, realidade de muitos dos meus alunos. Com as mãos calejadas, mal conseguia segurar o lápis.

Assim como seu Antônio, muitos alunos não conseguiam coisas básicas, como fazer cópia da lousa ou mesmo reconhecer a dimensão espacial do caderno. Aquele estranhamento fazia-me questionar como alfabetizar se antes faltava algo essencial aos alunos. Com a ajuda de minha orientadora, a saudosa Profa. Dra. Roseana Costa Leite ${ }^{2}$, pensamos propostas com ênfase em experimentações plásticas como primeira pincelada de trabalho. Para aquele momento, optamos em trabalhos com argila, pintura, desenho e até mesmo modelagem de massinha, que passaram a ocupar todo o galpão em que dava aula. Acreditávamos que, primeiro, os alunos precisavam experienciar e envolver-se plasticamente com o corpo para que, depois, pudessem iniciar um processo de alfabetização. Ainda hoje, vejo como um elo fundante para as aprendizagens as experimentações plásticas e o corpo em movimento; ele também fala, produz conhecimento e é um disparador

2. Roseana foi minha professora na graduação, como também coordenadora do Projeto de Extensão Universitária PE JA (Programa de Educação de Jovens Adultos), do qual fu bolsista durante o ano de 2005. Em 2009, infelizmente, veio a falecer por decorrência de um câncer. 
de processos educativos. Essa talvez tenha sido minha primeira experiência, ainda que bastante embrionária, como arte/educadora.

Atuar como professora de EJA foi um acontecimento bastante significativo em minha formação - talvez tenha sido a partir daí a assimilação de que a educação se dá de forma dialógica entre os sujeitos envolvidos, educadoras e educadores, alunas e alunos, em uma perspectiva coletiva de trabalho e aprendizagem. As singularidades envolvidas em um processo dessa natureza ampliam as percepções sensíveis que o conhecimento pode mobilizar; torna-se, então, um elemento-chave para a formação de um pensamento pedagógico. A sala de aula mostra-se exatamente um lugar de diferentes formas de perceber o mundo, o conhecimento e as aprendizagens. Os estudantes são múltiplos, e nós, professoras, também compomos nossos conhecimentos quando atuamos em grupo e aprendemos juntas.

Esse trabalho durou apenas um ano pois, por falta de verbas, a Universidade cortou parte das bolsas e fui obrigada a sair do projeto. Passei um tempo sem saber o que fazer, pois o curso de Pedagogia realmente não me estimulava muito. Faltava alguma coisa nas aulas, um sopro. Lembro-me que ficava bastante entusiasmada em assistir às aulas do curso de Ciências Sociais, com o Prof. Dr. Raul Fiker ${ }^{3}$, sua disciplina era Filosofia. As aulas sempre tratavam de temas como surrealismo, literatura, poesia e teatro. Lembro-me até hoje de uma aula sobre o livro Uivo ${ }^{4}$, de Allen Ginsberg - a forma como o professor declamava os poemas me trazia imagens muito fortes e aquilo, até hoje, é presente em minha práxis. Poesia, artes e política eram os assuntos sobre os quais eu mais gostava de refletir e discutir com meus colegas. Em 2007, caminhava para finalizar a graduação e encontrava-me bastante perdida sobre os rumos que tomaria profissionalmente. A ausência de estudo e de experiência com a arte como forma agregadora de conhecimento era bastante presente e não tinha ainda uma ideia clara de como resolver o problema.

No meio do primeiro semestre de 2007, no entanto, um fato histórico transformou decisivamente minha trajetória - outro desvio que se fez presente. Estudantes, funcionários e professores das Universidades públicas do Estado de São Paulo (USP, UNESP e Universidade de Campinas - UNICAMP) entraram em greve. Sempre frequentava as assembleias estudantis e, para minha surpresa, em uma delas, nos chegou o informe de que os estudantes da USP haviam ocupado a reitoria.

3. Raul foi professor do curso de Ciências Sociais e membro do departamento de Filosofia, embora não tenha sido meu professor efetivamente, gostava muito de assistir suas aulas como aluna ouvinte. Em 2017, lançou um livro de contos chamado "O Equivocrata, uma reta de vista", foi a última vez o que vi, pois veio a falecer no final daquele ano.

4. O livro de poemas intitulado Uivo (Howl, escrito pelo poeta norte-americano Allen $O$ livro de poemas intitulado Uivo (Howl), escrito pelo poeta norte-americano Allen
Guinsburg, foi lançado nos Estados Unidos em 1956.
Conseguimos um ônibus e fomos até São Paulo conhecer a ocupação. Lembro-me perfeitamente do cheiro daquele lugar. A atmosfera juvenil, o ânimo das conversas e as discussões enchiam-me de esperança. Em uma roda falava-se em revolucionar a universidade e torná-la uma extensão da própria vida. Uma estudante da Faculdade de Arquitetura e Urbanismo FAU/USP, Débora Oelsner Lopes, ${ }^{5}$ que depois de um tempo se tornou uma de minhas grandes amigas, apresentou-me ao construtivismo russo ${ }^{6} . \mathrm{Na}$ época, ela fazia teatro e me contou que a produção da Rússia revolucionária era um forte elemento de formação em seu grupo teatral. Os sonhos possíveis dos estudantes, as utopias de transformação, são algo que até hoje reverberam em minha condição humana. Walter Benjamin, em seu ensaio "A vida dos estudantes", nos lembra que:

O estudantado seria visto assim em sua função criativa, como o grande transformador com a missão de converter em questões científicas, através de posicionamento filosófico, as ideias que costumam desperta antes na arte e na vida social do que na ciência. (2002, p. 41 e 42)

É justamente com esse despertar, como profere Walter Benjamin, que aconteceu minha atuação política em defesa da universidade pública de qualidade. Assim, encontro uma função criativa para minha vivência enquanto estudante e que ecoa, até hoje em dia, no modo em que procuro atuar no mundo. Foram as questões despertadas pela arte e pela vida social que me geraram outras buscas, novos caminhos para compor minhas práxis docente, artística-humana. Esse posicionamento político primeiro nunca mais saiu do meu corpo e memória.

Resolvo, em 2008, finalizar a graduação na Faculdade de Educação da Universidade de São Paulo, após ter concluído a maior parte da minha formação em Araraquara. Faltavam ainda algumas optativas e, por ter vivenciado intensamente a greve e ocupação das universidades públicas do estado de São Paulo, opto por finalizar a graduação em sistema de intercâmbio na FEUSP.

Venho à cidade de São Paulo para procurar algo que estava me faltando na graduação. A construção de utopias, de transformação da universidade em um espaço dialógico com o mundo, a busca do teatro, da arte e de novas possibilidades de atuação como professora me moviam. Assim, fui

5. Débora graduou-se em Arquitetura e Urbanismo pela FAU/USP e é mestre em Arte Cênicas pela Universidade Federal do Estado do Rio de Janeiro. Atualmente leciona como professora substituta na graduação do curso de cenografia da Universidade Federal do Rio de Janeiro.

6. O construtivismo russo foi um movimento das vanguardas russas de caráter estético-político, que eclodiu por volta de 1919. Teve muita força na Rússia revolucionária e pretendia fundir a vida com a arte. Tem como ícones alguns artistas plásticos como: El Lissitzky, Malevich, Tatlin e na poesia teve Vladimir Maiakóvski como um de seus representantes. 
me formando pedagoga, vivenciando os espaços estudantis, as aulas, as assembleias, as festas e os atos.

Frequentando três optativas na FE, acabo por escolher as disciplinas pela nomenclatura, não me atentando às ementas. Me matriculei em (EDF0686) - A Escrita no Ensino Fundamental I: das Letras aos Textos; (EDM 0676) - Música e Formação de Professores e (EDM 0331) - Metodologia do Ensino de História e Geografia. As aulas, de modo geral, não me traziam paixões. Acreditava que encontraria reflexões e problematizações sobre a Arte na Educação. Por não encontrar este espaço, fazia apenas o que era necessário. Dediquei-me com mais entusiasmo à disciplina sobre música e formação de professores, mas, ainda assim, eu não percebia nada de transformador. Aprendi algumas canções para trabalhar com as crianças, contudo, achava tudo muito infantilizado. Não discutíamos questões de como as crianças poderiam se relacionar com a linguagem musical ou mesmo como elas poderiam expressar as buscas desse conhecimento. Ficava ainda uma sensação de falta, algo que elevasse meu pensamento, ao mesmo tempo, de forma mais crítica e criadora.

\subsubsection{O teatro me ensinou a vida}

Fora das paredes das salas de aulas, a vivência estudantil era intensa. Frequentava diariamente o CAPPF (Centro Acadêmico Professor Paulo Freire) e foi lá que conheci muitos estudantes do curso. No meio do ano, montamos uma chapa chamada Parrésia ${ }^{8}$ para disputar as eleições do centro acadêmico. Nesse meio tempo, tornei-me atriz do grupo teatral Coro de Carcarás ${ }^{9}$ e, semanalmente, ensaiávamos na FAU. O grupo era composto por estudantes de diversos cursos de graduação da Universidade de São Paulo - pessoas ligadas à Música, à Arquitetura, ao Cinema, às Artes Plásticas, à Filosofia, às Letras. O grupo tinha um forte caráter multidisciplinar, além da linguagem teatral. Geralmente, realizávamos apresentações nas festas estudantis. Entre os anos de 2007 e 2009, nossa atuação ainda era muito focada na USP. Mais tarde, nos lançaríamos como grupo teatral fora

7. Essa frase é do professor, arquiteto e cenógrafo Flávio Império e encontra-se no filme "REVERSO" Parte I. Dirigido por Cao Hamburguer e Raimo Benedetti, 1997. No $2^{\circ}$ ato desta dissertação há uma nota de rodapé onde escrevo outros atravessamentos provocados por Flávio. O vídeo está disponível em: https://www.youtube.com/watch?$v=3 j \mid$ QgTHqtUM. Último acesso em: 23/05/2019.

8. Parrésia foi o nome sugerido por um colega de graduação, Marcos Guerra, a palavra de origem grega trazia o sentido de confiança, franqueza e ousadia ao falar em público.

9. Este nome foi escolhido em homenagem ao Show Opinião dirigido por Augusto Boa e produzido pelo Teatro de Arena durante os anos da Ditadura Militar A música "CarTerizada na voz de Maria Bethânia. dos muros da Universidade, realizando apresentações no Teatro de Arena, Teatro União e Olho Vivo, entre outros.

Nos anos de atuação no grupo Coro de Carcarás, procurávamos desenvolver uma pesquisa vislumbrando, na arte e no teatro, formas de refletir e atuar sobre a nossa condição humana. Pensávamos o teatro como um ato político, uma arma potente para problematizar a vida e fazer dela a busca por algo novo. Neste sentido, fomos bastante influenciados pelo construtivismo russo e por outros movimentos que buscaram na arte uma maneira de revolucionar a vida. Ao estudar as vanguardas russas e descobri-las como ato político na tentativa de uma transformação radical por uma nova sociedade, a formação de um pensamento educativo inserido em uma perspectiva política, artística e pedagógica, mostrou-se fundamental.

A vanguarda russa buscava criar uma nova pedagogia artística e muitos artistas também eram professores. Na verdade, atuavam como sujeitos múltiplos, sujeitos que pretendiam existir não apenas como artistas mas, também, como educadores e agentes políticos de um novo mundo que se apontava. Entre 1917 e 1919, um grupo de artistas russos ligados ao teatrólogo Vsévolod Meierhold ${ }^{10}$ desenvolveu uma forma especial de pensar a arte em fusão com a vida. Evidentemente, não permaneceram limitados apenas a uma expressão artística, buscando trabalhar sempre o amálgama de diversas linguagens. Meierhold, por exemplo, pesquisou e desenvolveu uma pedagogia experimental do campo das artes, expandindo seu trabalho como professor, diretor e atuador político. Béatrice Picon-Vallin ao investigar o longo período de atuação e criação de Meierhold, descreve como ele desenvolvia seu pensamento na relação de uma pesquisa teatral voltada para uma nova pedagogia do teatro, ou seja, para a formação de atores políticos:

A pedagogia ligada à pesquisa tem para Meierhold um valor absoluto e experimental. Não é uma atividade paralela à existência de um teatro, porém uma atividade fundamental destinada, em primeiro lugar, a cimentar um coletivo capaz de fundar um teatro correspondente às

10. Meierhold, um dos grandes ícones da vanguarda russa, foi professor, encenador, ator, diretor, militante do partido bolchevique e de tantos outros papéis atribuídos a ele. Era um dos mais importantes atores do Teatro de Arte de Moscou e foi o criador de uma nova concepção de teatro chamada Biomecânica, da qual fazem parte estudos cênicos a partir da ideia do homem enquanto máquina afetiva. Compreendia o teatro como um espaço coletivo e, de fusão total com a vida. Compôs sua obra de forma multidisciplinar com outros artistas da vanguarda soviética, tais como Maiakóvski, Eisenstein, Popova, entre outros. Seu teatro era visto por operários e foi muito importante nos anos de consolidação do comunismo da antiga URSS. Preso em 1938 pela polícia política de Stalin e fuzilado no ano seguinte, deixou um enorme legado para o pensamento criador do teatro e pedagógico das artes. Ver em: Meierhold, PICON-VALIN Béatrice. São Paulo: Perspectiva, 2013. 
A partir dessas referências, tentamos construir um teatro que nos levasse a não representar, mas fazer da representação teatral um ato criador - uma possibilidade de diálogo com o mundo e seus acontecimentos. Em meu trabalho recente como educadora, tento aproximar alguns elementos do que Meierhold desenvolve em suas pesquisas pedagógicas para a formação de atores, o que ele próprio denomina uma pedagogia experimental, à minha própria práxis pedagógica. No princípio do século 20, o artista russo estava vislumbrando pensar a constituição das atrizes e de atores relacionando-os a uma nova noção humana apontada pelos anos da Revolução Russa. Assim, criou o GVYTM (Ateliês Superiores do Estado de Encenação). Procurava, então, desenvolver em suas práticas uma apropriação dos atores e atrizes como fábrica de futuros homens (PICON-VALLIN, 2013, p.114). Além de buscar um processo dialógico onde todas e todos aprendiam a relacionar-se com as demais linguagens e, assim, criar um corpo único para encenação voltado para aquele momento histórico, era um teatro a serviço da revolução. As artes cênicas ligavam-se às artes plásticas, à poesia e aos elementos presentes naquele cenário de grandes transformações sociais. Era a vida que fazia o teatro e o teatro expressava, por sua vez, como a compreendia.

Nos tempos de universidade, pensamos em experimentar $\mathrm{o}$ ato teatral no "Coro de Carcarás" a partir de como compreendíamos os trabalhos realizados pela vanguarda russa. Éramos um grupo teatral que também buscava atuar dialogicamente com outras linguagens artísticas, agregando estudantes de música, arquitetura, letras, filosofia, artes plásticas e até mesmo física. Era um trabalho de laboratório de aprendizagens: todas e todos estavam em processo de troca de conhecimentos. Mais do que isso, para nós, era fundamental pensar em uma arte que se fundisse com a própria vida. A atuação nas universidades ia a esse encontro, pensávamos que nossa tarefa como estudantes de instituições públicas era fazer do teatro uma lente de aumento das questões sociais. A ideia era provocar na plateia questões críticas em que o ato cênico promovesse ações de contestação das mazelas sociais.

A primeira peça em que atuei foi uma adaptação de Ascenção e queda da cidade de Mahagonny, de Bertold Brecht. Participamos da recepção aos novos estudantes da FAU em 2008, no centro da cidade. O objetivo da peça era dialogar diretamente com a cidade de São Paulo. Na peça original, a cidade de Mahagonny é construída com grande entusiasmo e promessas de uma vida melhor. Lá, tudo era permitido. Aos poucos, essa permissão foi ganhando espaço para proibições e os moradores se veem em uma situação calamitosa, ainda mais com a chegada de um furacão. Criamos a encenação com o intuito de provocar uma discussão sobre as proibições na cidade e, também, apontar problemas urbanos como a falta de moradia para as pessoas. Esse trabalho foi desenvolvido por um ano, atuamos nas demais recepções dos novos estudantes na FFLCH. Ao longo do ano, éramos convidados para atuar em algumas festas realizadas na Universidade de São Paulo.

Assim, sucederam-se os anos seguintes, em 2009, criamos o roteiro Vladimir no país da gramática, peça autoral em que narramos a vida e obra do poeta russo Vladimir Maiakovski. Como em todo ano, montávamos as peças para recepção dos novos estudantes da Universidade de São Paulo, sempre almejando tencionar questões sociais presentes e provocando na plateia uma reação ativa e participativa sobre encenação. Nesse ano, no entanto, passamos a realizar um festival de contracultura para ampliarmos diálogos com demais grupos teatrais e musicais, e lançamos nosso manifesto no Teatro União e Olho Vivo. Começamos a pensar uma atuação fora dos muros da Universidade.

(...) O coro de Carcarás urbanos não faz teatro, cinema, maracatu. Não!

O nosso coro não faz uma linguagem que seja re-presentação! Nosso coro faz uma linguagem que é ato, puro ato, que caminha nas ruas, que se manifesta nas ruas, que toma conta das ruas da cidade em ruínas.

Por uma frente de criação e produção nas escolas, universidades, teatros e ruas.

(...) Nova poesia do sertão de concreto-armado de nossas cidades. Para levantar geral, derrubar o alambrado e tomar a cena no planalto central."

São Paulo, 31 de maio de 2009.11

Em 2009, atuava como professora auxiliar de um colégio judaico e, por se tratar de uma pedagogia bastante tradicional, não sentia muito espaço de criação como professora. Foi um ano em que dediquei muita energia ao grupo teatral. Além de atriz, passei a atuar em uma frente que pudesse ampliar nosso diálogo com os demais grupos teatrais. Resolvi cursar, como aluna ouvinte, uma disciplina oferecida nas Artes Cênicas da ECA/USP. O

11. O Manifesto Coro de Carcarás foi publicado em maio de 2009, nele escrevemos sobre nosso percurso formativo, as referências artísticas que o grupo incorporava, como também, fotografias dos espetáculos e uma entrevista com o teatrólogo Jós Celso Martinez Corrêa. Arquivo pessoal da autora. 


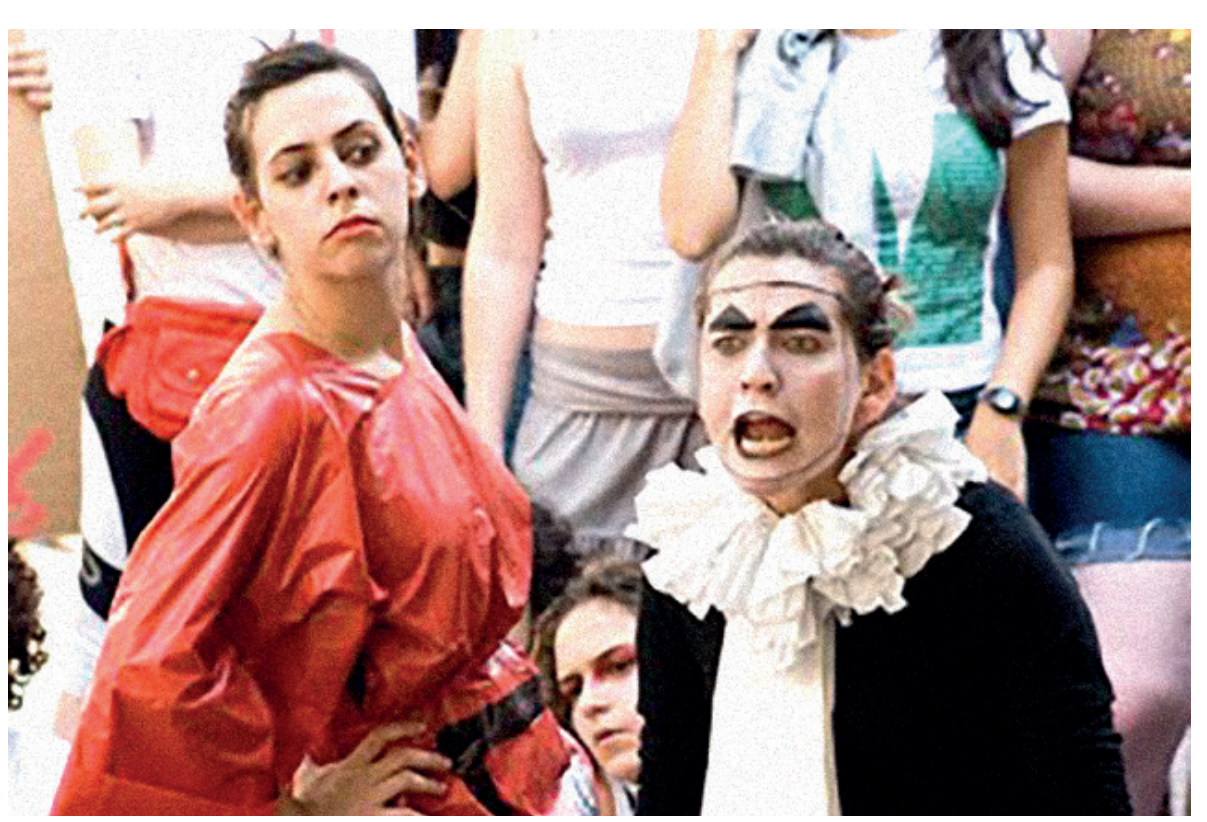

Figura 2. Encenação da montagem de "Vladimir no país da gramática". Nessa ocasião, atuei como "General das Artes", um agente repressor das produções do poeta Maiakóviski. Ao meu lado está Beatriz Cyrineu. Os figurinos foram criados por Débora Oelsner Lopes, a partir de pesquisas relacionadas aos construtivistas russos. Foto: Ed Viggiani. Praça do Patriarca, 2009.

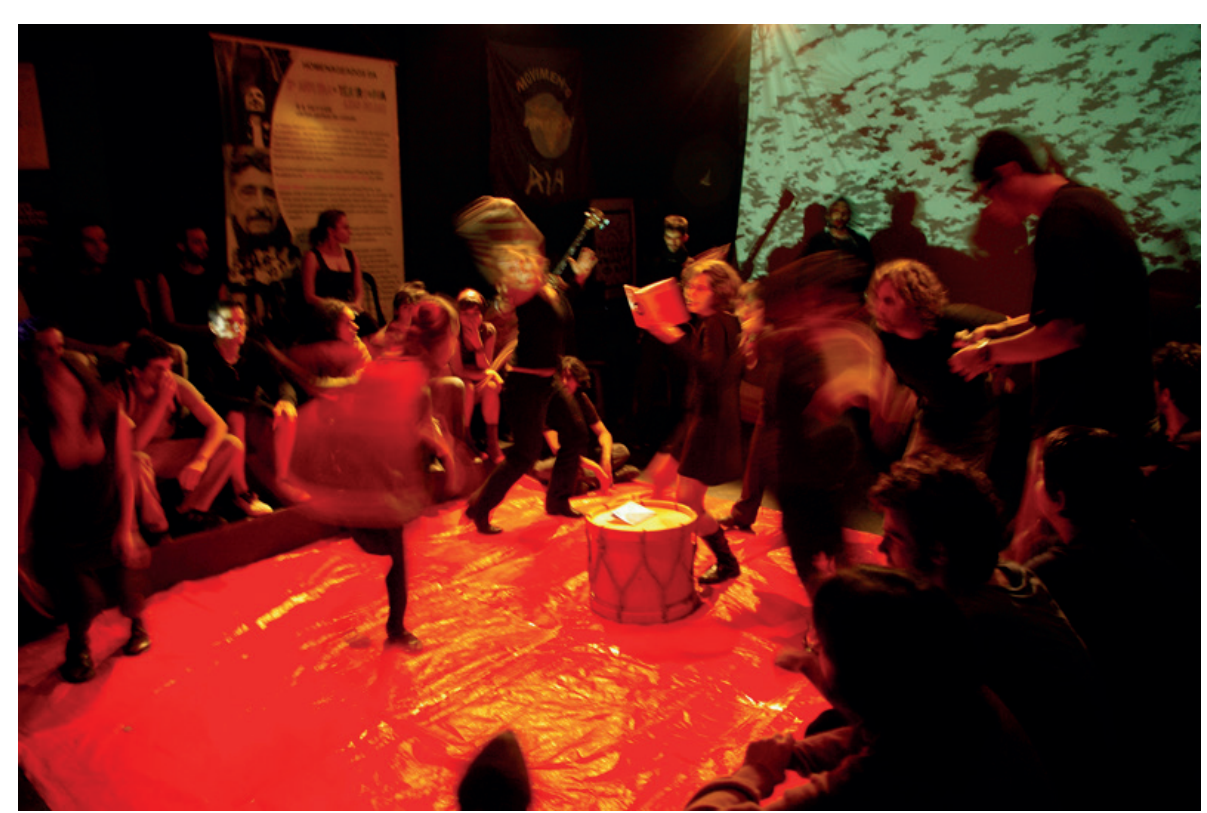

Figura 3. Lançamento do Manifesto Coro de Carcarás, eu ao centro lendo para o público nosso manifesto. Foto: Maíra Suzuki. Teatro União e Olho Vivo, 2009. curso era oferecido pelo Prof. Dr. Antônio Araújo e chamava-se O processo Colaborativo como modo de criação. Como parte da pedagogia teatral do Coro de Carcarás estava voltada para a horizontalidade dos processos criativos, vislumbrei um diálogo interessante com a disciplina. Pesquisamos, ao longo do semestre, como os processos colaborativos deram-se em alguns grupos teatrais no Brasil. Foi uma excelente reflexão porque partíamos do conceito de trabalho coletivo e colaborativo voltados para as práticas teatrais. Para o trabalho final, pesquisei a peça Bumba, meu queixada, do Teatro União e Olho Vivo, e realizei uma entrevista com o César Viana, diretor do grupo.

A consolidação de um trabalho coletivo era um grande desafio: embora tivessem papéis estabelecidos, cada sujeito envolvido carregava suas singularidades. Éramos estudantes universitários de diversos cursos e a universidade nos parecia um grande laboratório de aprendizagens. Tínhamos diretor, diretora de arte, diretor musical, grupo de cinema, preparadores corporais, o coro de atrizes, atores e tambores - tocávamos maracatu em nossas apresentações. Nosso intuito, teoricamente, era horizontalizar os processos. Muitos de nós passaram a assumir o grupo com uma nova perspectiva de formação e atuação profissional. As contradições apareceram, contudo, nas relações e nas dificuldades de um trabalho coletivo descentralizado. Infelizmente, a liberdade e a horizontalidade não aconteciam - tudo era bastante focado na figura do diretor. Ao final, ele ditava as regras e tínhamos vários impedimentos. $\mathrm{Na}$ época, éramos na maioria atuantes de um grupo político estudantil, não conseguíamos ter independência deste grupo. Os parceiros que não atuavam nessa frente sentiam-se deslegitimados, com toda razão. Esses obstáculos levaram à saída de muitos membros do grupo. Nossa utopia de criar um teatro que fosse ato, alçou voos limitados. Resolvo, então, sair do grupo no início de 2012. Lembro-me que meu ultimo grande papel foi a Prissípikin em uma adaptação da peça O Percevejo, de Vladimir Maiakóviski. Apresentamos esse espetáculo entre 2010 e 2011. Recordo que fizemos uma apresentação muito forte e marcante ao final de 2011, no Teatro de Arena. 


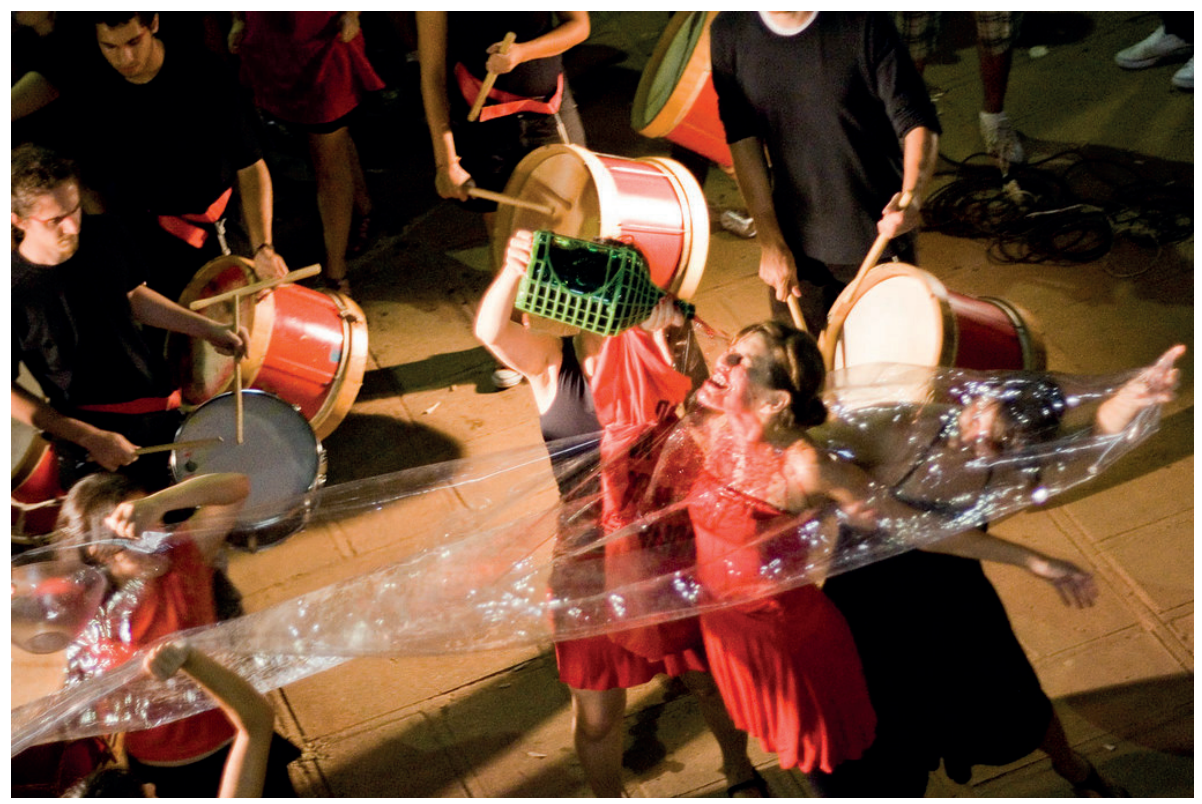

Figura 4. Adaptação de "O Percevejo" peça de Vladimir Maiakóviski. Atuava na interpretação de Prissípikin. Na peça original, ele é um antigo operário do regime soviético que é congelado para, anos depois, ser descongelado. É seduzido

pelo aburguesamento da nova Rússia, traindo sua classe e casando-se com uma mulher que lhe garante ascensão social. Na adaptação, a personagem ganha um ar feminino, como mulher. Ao descongelar-se, procura novas formas de viver: não trair sua classe e acordar as pessoas com rituais e festas. Foto: Fernando Stankuns, Faculdade de Filosofia, Ciências e Letras - USP, 2010.

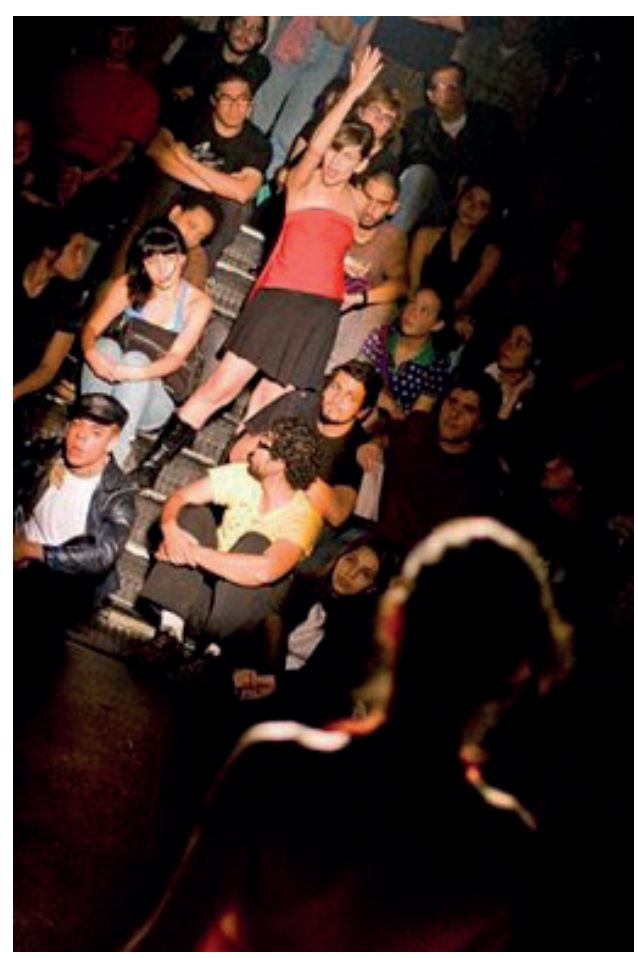

Figura 5. Última atuação. Foto: Maíra Suzuki. Teatro de Arena, 2011

\subsubsection{A sala de aula me fez professora}

A saída do grupo culminou com um processo importante. Embora já estivesse formada como pedagoga desde 2008, foi neste momento que passei a me debruçar de forma mais consciente sobre minha atuação como professora. Mesmo saindo da universidade, de certa forma, ainda mantinha um vínculo muito forte com a USP. Ao concluir a graduação, com esses anos todos como atriz, sentia que, de alguma forma, ainda estava atada à condição de estudante. Não frequentava mais as aulas, mas os espaços oferecidos pela instituição ainda eram muito presentes em meu cotidiano.

Foi justamente no ano em que saí do Coro de Carcarás que assumi minha primeira turma como professora no Colégio Equipe ${ }^{12}$. Trabalhava lá desde 2011, primeiro como professora auxiliar e depois me tornando professora de uma turma de 20 ano do Ensino Fundamental I. Era também professora do período estendido, lugar em que passei a atuar como arte/ educadora, sem ainda ter uma consciência dessa nomenclatura. Foi justamente a querida Ausônia Donato, diretora pedagógica do colégio, que me chamou a atenção para essa busca. Em uma conversa, ela me disse: Filhinha (forma carinhosa como costuma chamar as pessoas), você é uma arte/educadora, pense nisso e vá procurar formação para expandir esse trabalho.

Passo, assim, a construir um caminho mais consistente para minha prática pedagógica. Em uma linha do tempo, considero que a busca da docência deu-se, primeiro, com a aproximação ao pensamento de Paulo Freire, e se materializou pela minha experiência docente ao longo destes dez anos, somados à minha relação com o teatro. Passei a perceber que a sala de aula era um lugar de acontecimentos - como o teatro - e que de lá podemos extrair diversas formas para se chegar ao conhecimento. As linguagens artísticas tornaram-me mais sensível ao me relacionar com as crianças: meu pensamento pedagógico, ao assumir a tarefa como professora e artista, procura não segmentar as áreas de atuação, embora ambas tenham suas particularidades e componham a mesma pessoa, a artista e a professora.

Volto agora à minha reflexão docente e percebo que minha grande dificuldade como professora era expressar uma experiência que não tinha acontecido na minha graduação: não estudei, tampouco refleti sobre o lugar da arte na pedagogia. A graduação em Pedagogia deu-me, por outro

12. O Colégio Equipe foi fundado na cidade de São Paulo, em 1968. Inicialmente como cursinho, para que, anos mais tarde, se tornasse uma escola de Educação Infantil até o Ensino Médio. 
lado, uma noção dialógica para as relações e construções do conhecimento mútuo entre alunos, alunas, professoras e professores. Foi justamente a partir desses alicerces que passei a pensar o lugar da arte na escola e a ser capaz de tentar assimilar a experiência que vivi como atriz em sua potência pedagógica para meu trabalho enquanto professora.

Durante a graduação, ainda que de forma embrionária, via uma grande potência nas linguagens artísticas como perspectiva para minhas práticas educativas. A relação com o universo infantil só se intensificou. As crianças mostram-se potenciais artistas, pensam de maneira múltipla, são arteiras, criam universos infinitos ao brincar, ao desenhar, ao escrever uma história, e até mesmo ao lidar com um problema difícil de se resolver na aula de matemática. Nessa direção, Hélio Eichbauer ${ }^{13}$, quando é indagado sobre como é ensinar arte, afirma que:

(...) A arte é uma atividade, um ofício ligado à nossa infância. A criatividade da infância, da criança. A criança nasce artista e arteira, porque ela reinventa o mundo, ela transforma o mundo e cria personagens, diálogos, personagens fantasmas. Do lixo ela cria um brinquedo. A criança é o grande artesão artista. (2015)

Posso afirmar hoje que, primeiramente, a relação com o universo infantil fez-me artista e pedagoga. Na relação com as crianças, descobri o que Eichbauer afirma ser a arte como atividade - um ofício ligado à infância. Assim, observo as crianças, narradores de experiências, mostrando-me que há inúmeras possibilidades de criar, de brincar, de reinventar e de transformar a vida e o conhecimento. A pedagogia trouxe-me o campo da educação, as reflexões sobre as práticas educativas, a escola, a sala de aula e a escolha por um caminho docente pautado pela dialogicidade. Ou seja, pela comunhão do conhecimento que troco com minhas alunas e alunos e na relação que pretendo estabelecer com o mundo - como ensinou Paulo Freire. $O$ ofício da arte auxiliou a atriz e arteira a buscar novas formas de criar e reinventar o mundo, escolhendo a linguagem teatral como uma potência viva de ampliar o olhar sobre a experiência de viver o tempo histórico presente.

A princípio, a fundamentação da importância da arte na escola mostrava-se distante de minha prática escolar. No entanto, intuitivamente, era

13. Hélio Eichbauer (1941-2018) foi professor e um dos maiores cenógrafos brasileiro. De muitos de seus trabalhos no teatro, destaco o cenário da peça $O$ Rei da Vela montada pelo Teatro Oficina, durante os anos de ditadura militar, e a remontagem em 2018, ano de seu falecimento. Foi um dos professores e fundadores da Escola de Artes Visuais (EAV) no Parque Lage, Rio de Janeiro. Sobre Hélio ler a dissertação: A inquieta busca cenógrafa: a experiência didática de Hélio Eichbauer nos anos de 1970. Escrita por Débora Oelsner Lopes, na Universidade Federal do Rio de Janeiro, 2015. capaz de fazer essa relação. Meierhold e as demais referências artísticas e teóricas do Coro de Carcarás não escreveram para um teatro infantil, não atuaram propriamente em uma escola para esse universo, por exemplo. Havia, no entanto, um processo de aprendizagem que trazia ao teatro uma perspectiva pedagógica. Sobretudo, o pensamento de um trabalho coletivo onde, mais uma vez, a singularidade de todas e todos são garantidas. Neste sentido, Paulo Freire nos diz que:

Faz parte das condições em que aprender criticamente é possível a pressuposição por parte dos educandos de que o educador já teve ou continua tendo experiência da produção de certos saberes e que estes não podem a eles, os educandos, ser simplesmente transferidos. Pelo contrário, nas condič̃es de verdadeira aprendizagem, os educandos vão se rró, nas condiçóes de verdadeira aprendizagem, os educandos ão do saber ensinodo, ao lado do educador, igualnente sujeito do processo. (p. 28, 2016)

Como sujeita da história, aprendiz e professora, passo a olhar nos caminhos da pedagogia um processo de uma eterna busca de aprendizagens - um processo da construção do saber na relação com as minhas alunas, alunos, professoras, professores, colegas de trabalho e a própria realidade posta. Foi do encontro que estabeleci entre a pedagogia e as práticas artísticas que pude perceber que, em muitos casos, os artistas trazem em comum com as crianças a atuação no mundo de forma criadora. As crianças carregam uma característica arteira, como afirmou Helio Eichbauer, de inventar novas possibilidades para uma vida mais livre. Do saco de lixo, uma capa de herói e heroína. Da experiência vivida, uma história para aula de língua portuguesa ou um roteiro para ser atuado.

Aproximar o teatro da pedagogia é um braço fundamental para que se possa realizar um trabalho educativo em sala de aula. $O$ curso de pedagogia, a partir do que reflito nesta escrita, não trouxe o elo que eu procurava para pensar a Arte/Educação e a Pedagogia. Não vivenciei essa experiência nas aulas e na formação. A universidade, sobretudo a USP, no entanto, trouxe-me a experiência de viver o teatro, a arte e a educação fora das paredes da sala de aula. Foi muito importante ter vivido a experiência como estudante em uma instituição pública de ensino. As universidades públicas geralmente oferecem vivências que transbordam às aulas - no encontro com pares, nos espaços estudantis, nas festas, nos atos, nas assembleias e em todas as buscas que permeiam nossa condição enquanto estudantes.

14. O livro Pedagogia da Autonomia: saberes necessários à prática educativa, foi publicado pela primeira vez no ano de 1996 . Utilizo nesta escrita a $53^{2}$ edição. 


\subsection{UMA EXPERIÊNCIA PARA NARRAR}

A atuação em grupos teatrais foi presente em minha vida dos anos de 2008 a 2015. Neste período, foi com as práticas educativas e artísticas que encontrei um suporte para minha atuação como professora e artista. Há um caráter experimental na minha constituição como pedagoga para o ensinar, ou melhor, para o possibilitar experiências que dialoguem com o campo das artes em sala de aula. Essa formação ganhou corpo na experiência dentro das instituições de ensino e nos grupos de teatro em que trabalhei.

De modo geral, nunca atuei em um teatro dito infantil. Minhas referências artísticas teatrais transitam sobretudo por concepções de teatro que buscam aproximá-lo da vida. Por exemplo, na pesquisa e no trabalho que desenvolvemos no Coro de Carcarás, o teatro ganha uma dimensão política e social quando entende e incorpora em seus atos a urgência de uma vida permeada por contradições muitas vezes brutais. É justamente por compreender essa urgência que ele atua na tentativa de provocar desejos de transformações sociais e, de forma mais ampla, da criação de possibilidades de um novo modo de viver. Espera-se que os espectadores, postos em movimento, possam agir em seu cotidiano, capazes de exercer uma expressão mais coletiva, reinventando o dia a dia massacrante provocado por uma sociedade com abismos sociais e culturais enormes.

O teatro vivifica um caráter educativo, pois estabelece um diálogo com o mundo, como afirma Paulo Freire. Para ele, o ato educativo acontece em uma comunhão com o mundo. Muitos artistas encontram na arte a força viva de se opor às contradições sociais e, assim, também comungam o mundo. A linguagem teatral mostra uma possibilidade de atuação de forma crítica, tal qual a prática docente. Artistas e professores tornam-se sujeitos da história. Pensar uma pedagogia nessa perspectiva leva-nos a estabelecer um diálogo com o pensamento de Antonin Artaud. Compreende ele que o teatro, como a peste, é algo que devasta a humanidade. Ao mesmo tempo em que aponta para a destruição, traz com ela a criação de algo novo, novos sujeitos históricos:

O mais urgente não me parece tanto defender uma cultura cuja existência nunca salvou qualquer ser humano de ter fome e da preocupação de viver methor, mas extrair, daquilo que se chama cultura, ideis ção de viver melhor, mas extrair, daquilo que se chama cultura, ideias cuja força viva é idêntica à da fome. (ARTAUD, 2006, p. 1)

Essa urgência me faz refletir sobre diversos âmbitos da vida. Observo na educação escolar a existência de uma possibilidade de encontro com tais forças vivas, como descreve Artaud. A sala de aula é a interlocutora de relações e nela realiza-se um caminho dialógico a partir de correspondências estabelecidas nesse espaço. Correspondências essas que vão desde uma escuta atenta ao que os estudantes almejam para construir seu conheci- mento até a possibilidade de mudar os caminhos postos em prática frente a uma demanda do grupo de alunos.

Algo, então, instiga-me em relação à interlocução das linguagens artísticas com as práticas educativas; questionando meus caminhos, encontro diálogos entre o campo da Arte/Educação e a Pedagogia. De fato, esses diálogos não acontecem em algumas instituições de ensino e cada vez mais essa questão tem sido investigada. Esse problema fica evidente pelo profundo debate realizado na contemporaneidade por diversos pesquisadores. O professor Afonso Medeiros diz que:

No sistema educacional brasileiro, como sabemos, cabe sobretudo ao licenciado em pedagogia a responsabilidade na orientação dos processos de ensino e aprendizagem do aluno nas séries iniciais. Se considerarmos que essa iniciação do educando deve se construir nos primeiros passos em grandes áreas do conhecimento (linguagens, ciências, humanidades e artes), de modo que ele possa ler, interpretar e interagir com a cultura que produz e que lhe produz, diríamos que entre essas áreas não pode haver hierarquia do tipo "mais e menos importante" e portanto, a formação do pedagogo deveria abarcar um amplo espectro de conteúd tro de conteúdos e habilidades e, assim, as artes (junto com as outras areas) estariam plenamente justificadas nos desenhos curriculares dos cursos superiores de Pedagogia. Mas essa percepção está longe de ser consensual e os motivos desse dissenso são múltiplos e conflitantes. (2017, p. 84)

No âmbito escolar, além de dar conta de demandas complexas referentes às diversas linguagens, a problemática que Medeiros levanta é fundamental; horizontalizar as áreas do conhecimento na formação é algo necessário e urgente. $\mathrm{O}$ campo da Arte/Educação estabelece um elo importante para auxiliar pedagogas e pedagogos a expandirem seus olhares diante dos conteúdos trabalhados, podendo costurar de maneira dialógica as áreas do conhecimento que abarcam sua prática educativa. Os professores da Educação Infantil, por exemplo, exercem a função das aulas de linguagens artísticas. No entanto, fica a questão: como podem promover experiências nesse campo sem que tenham vivenciado, ou vivenciado pouco, essas questões na graduação? Essa perspectiva revela uma lacuna que identifico desde já na constituição do currículo nos cursos de Pedagogia. Ainda sobre este aspecto, Medeiros aponta uma necessidade em relação à formação:

A necessidade de questionar a formação docente é uma constante nos cursos de licenciatura comprometidos com a dimeña formativa nos cursuda de licenciatura comprometidos com a dimensão formativa dos estudantes de graduação. E pensar as práticas pedagógicas nos cenários educacionais contemporâneos, tendo como foco a área de Arte vem sendo um grande desafio. (2017, p. 141)

Na tentativa de encontrar esse diálogo, escrevi, em 2016, um projeto de mestrado decidindo ingressar na pós-graduação. Voltei à Universidade de São Paulo, agora determinada a buscar no campo da Arte a fusão com 
a pedagogia. Escolhi o programa de Pós-Graduação da Escola de Comunicação e Artes, na área de concentração, Teoria, Ensino e Aprendizagem em Arte. Voltar a ser estudante da universidade tem sido uma experiência muito valiosa para minha prática docente, pois assim posso refletir de forma sistematizada a importância dos estudos sobre a experiência artística na formação dos licenciados em Pedagogia.

Essa reflexão, bastante importante na contemporaneidade, é realizada por diversas educadoras e educadores. Neste sentido, Luciana Ostetto, em sua tese de doutorado, problematiza a relação entre o campo da Arte e da Educação no curso de Pedagogia, a partir de uma experiência formativa com as danças circulares. Desse modo, ao pensar a arte como um conhecimento primordial, amplia o olhar ao dizer que "talvez esteja aí a possibilidade de incorporar a arte como conhecimento essencial, tirando-a da marginalidade a que esteve reduzida até agora, esquecida nos porões das escolas e da vida." (p. 176, 2006). Mais adiante, a autora defende a existência de arte nos currículos de formação nos cursos de Pedagogia para além das teorias e metodologias:

Refiro-me à presença da arte nos cursos de formação, em especial nos cursos de Pedagogia, não como conteúdo a que os professores deverão dominar para "repassar" para as crianças; mas que, em sentido contrário, contribua para a desestabilização desse domínio. Presença que se estenda para além dos moldes de uma disciplina com conteúdo específico, contemplando principalmente tempo-espaço para o professor redescobrir-se. Enfim, como um programa de formação cultural que considera a pessoa na pessoa do educador, no convite a voltar-se para si mesmo; onde a imaginação e o espanto possam ter lugar de destaque; que proponha experiências que contribuam para romper o destaque; que propontiexper

e, quem sabe, subverter o império da razão. (OSTETTO, 2006, p. 231)

A formação docente, assim, estabelece liames com o campo das experiências. Os estudantes podem vivenciar em sua formação inicial um espaço mobilizador e realizar um estranhamento das práticas estabelecidas nas disciplinas. Como salienta a autora, os estudantes se tornarão sujeitos capazes de promover questões acerca de si mesmos, possibilitando novas formas de atuar na vida e na escola, de descobrir caminhos que possam realizar o encontro entre Arte/Educação e Pedagogia, enriquecendo a pluralidade de repertórios para se trabalhar na sala de aula.

Ao contemplar meus caminhos nesses dez anos de escola, assim como minhas experiências artísticas, considero que pude estabelecer relações semelhantes àquelas que Ostetto revela quando diz sobre voltar-se para si mesmo. Penso nos estranhamentos que muitas vezes a práxis docente colocou em meus caminhos. Por isso, recordo um período e escolho uma experiência para narrar e refletir. Escavar todo meu percurso docente é quase uma arqueologia do imaginário: olhar fotografias, ler registros, parar para lembrar, pensar e refletir acerca desse processo de aprendizagem. O campo escolar, nesses anos, tornou-se um laboratório de pesquisas e experimentações. De fato, tive a oportunidade de trabalhar com grandes educadoras, educadores e instituições de ensino que me proporcionaram liberdade para essas experimentações. Sempre foram escolas particulares, escolas que, nos limites postos enquanto instituições de ensino privado, ainda que permeadas por contradições, preocupam-se em tornar o ensino um campo de aprendizagens que possibilite aos estudantes um olhar para o mundo de forma crítica.

Na linha do tempo de atuação, considero importante refletir acerca de um trabalho que realizei em 2014, assumindo pela primeira vez um grupo de primeiro ano do Ensino Fundamental I. Além dos conteúdos de Língua Portuguesa, Matemática, Ciências, História e Geografia, era responsável pelas aulas de Arte.

Por se tratar de uma série bastante voltada para os processos de alfabetização e conclusão da Educação Infantil, as disciplinas não são rigidamente fragmentadas e, portanto, há bastante flexibilidade na grade curricular. Durante todo o ano, procurei transportar para o ateliê o centro de nossas pesquisas. Na época, estava pesquisando sobre as escolas de Reggio Emilia ${ }^{15}$ e, como tal concepção de ensino, buscava relacionar os demais conteúdos trabalhados em sala de aula às pesquisas realizadas no ateliê de arte. Os materiais disponíveis naquele espaço passaram a ser suporte de nossa comunicação, tal como descreve Charles Schwall ao refletir sobre esse modelo de ensino:

O ateliê é uma oficina para as ideias das crianças, que se manifestam pelo uso de muitos trabalhos. O estilo de trabalho que adotamos é usar os materiais como linguagem. Nessa visão, os materiais são veículos para expressar, comunicar e fazem parte do tecido das experiências pro expres con condizagem das crianças, em vez de serem produs processos de aprendizagem das crianças, em vez de serem produtos separados. As crianças apresentam uma receptividade inata às possibilidades que os materiais oferecem e interagem com eles para criar significados e relações, explorar e comunicar. (p. 32, 2012)

A partir da ideia de comunicação e expressão na relação com materiais, procurei realizar no ateliê um centro gerador de nossas pesquisas. Um ca-

15. A cidade de Reggio Emilia situa-se no norte da Itália. Durante os anos de 1950, foram implementadas nessa cidade um modelo experimental de educação em pré-escolas e creches. Essas escolas nasceram de um forte movimento progressista do então secretário da Educação, o professor Loris Malaguzzi, bastante influenciado pelo trabalho de Piaget, Dewey, Montessori e outros pensadores da educação, psicologia, arquitetura e outros campos. A escola tem como um de seus principais pilares o ateliê de arte. Ele passa a ser o laboratório de investigação das crianças, professoras e professores. Ler $O$ papel do ateliê na educação infantil: A inspiração de Reggio Emilia. 
O primeiro semestre foi um período importante de formação daquele grupo. Muitas crianças vinham de outras experiências escolares, com momentos do processo de alfabetização e de conhecimento bastante singulares. $O$ ateliê nos ajudou. As experimentações plásticas e as rodas de apreciação foram contribuindo para que pudéssemos nos conhecer. Além disso, o ateliê foi transformado em um laboratório para as pesquisas em diversas áreas do conhecimento e não ficou restrito apenas às aulas de arte. Em ciências, por exemplo, estávamos pesquisando seres vivos e montamos um pequeno "jardim" para acompanharmos o crescimento de algumas plantas. Além do cuidado diário, as crianças realizavam desenhos de observação de nossas plantações. Foi importante, naquele momento, saber diferenciar um desenho de observação de um desenho de imaginação, já que nosso objetivo era uma pesquisa para o campo científico. A imaginação era necessária para construção de hipóteses acerca do crescimento das plantas. Para a realização dos desenhos de observação, no entanto, era fundamental que compreendêssemos que nossas plantas não tinham caras, nem sempre o dia estava solar, e quase nunca recebíamos a visita de borboletas, situações bastante presentes em um desenho advindo de um processo imaginativo. $O$ desenho, assim, passou a ser o fio condutor de perguntas relacionadas às plantas, já que, para desenhar, era preciso observar o desenvolvimento real delas. E assim foram decorrendo aqueles primeiros meses.

Além dos desafios de se iniciar um trabalho com essa faixa etária como professora, era também minha primeira experiência como professora de arte - um grande desejo realizado. Sentia-me, no entanto, bastante insegura e sem muito repertório para desenvolver outras possibilidades que não fossem o desenho e a pintura. Por mais que diversificássemos os suportes para realizar as propostas, nada fugia muito do convencional. A falta de ter vivido experiências e aprendizagens no campo das artes visuais na graduação trazia-me uma angústia. Tinha medo de ensinar um caminho confuso em relação à expressão do desenho. Sabia do compromisso em respeitar essa expressão, das buscas e necessidades que as crianças desenvolviam naquele momento, mas não sabia como potencializá-la. Faltava-me repertório para pensar os suportes de trabalho ou, até mesmo, ir além do desenho.

Era um desafio enorme. Em práticas anteriores de sala de aula, o cam-

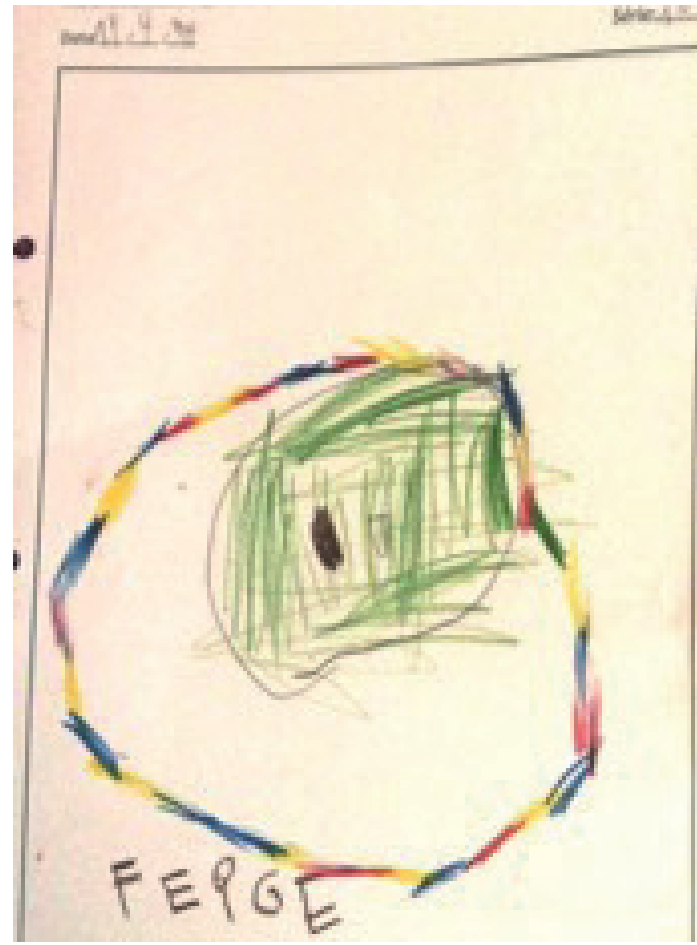

Figura 6. Na figura, desenho com lápis de cor: uma semente de feijão plantada pelas crianças. Essa foi a primeira semente plantada. Após cada criança plantar seu feijão, fizemos um desenho de observação desse processo, 2014.

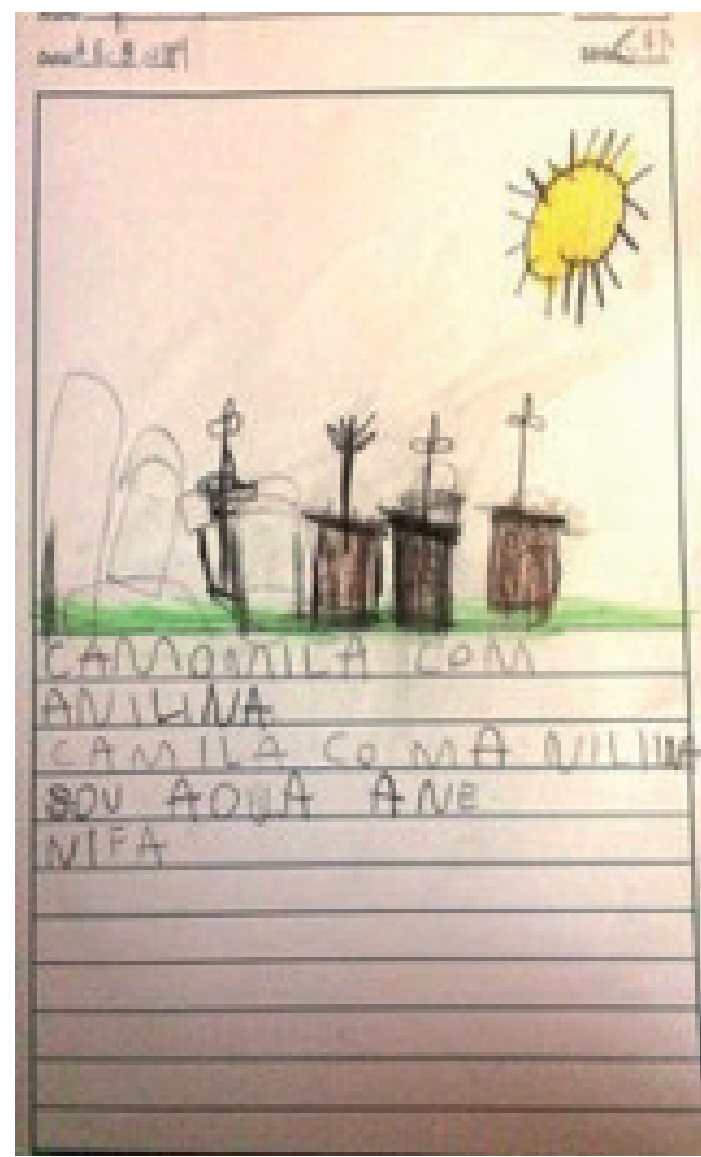

Figura 7. Na figura, desenho com lápis de cor e escrita com lapis grafite. Essa proposta foi realizada com o objetivo de que as crianças, além de desenharem o crescimento de nossas plantas, pudessem desenvalver a escrita de una lista do aucrita de uma lista do que estavam nos revelou como estava a pesquisa em relação à escrita. Esta criança, por exemplo, tinha construído uma escrita alfabética para algumas palavras, como por exemplo, "ANILINA", e para outras, não, como é o caso da junção de letras "AOUA", 2014. 
po da arte sempre passou pelas minhas pesquisas. Procurava relacionar as linguagens artísticas aos conteúdos trabalhados, e esse aspecto ia desde a criação dos processos de escrita à execução dos projetos. No entanto, não era professora de artes plásticas. Os objetivos de aprendizagem dialogam nesse campo de forma sensível e não como intencionalidade de ensino. A professora e a atriz formavam um sujeito indissociável no pensamento $e$ na práxis, ora docente e ora artista. Percebo, entretanto, que esta é uma formação mediada por contradições. O teatro formava-me uma pessoa mais sensível e capaz de realizar aproximações ao conhecimento de forma multidisciplinar - trazia um fator de realização e criticidade. À medida que atuava, relacionava-me comigo mesma de outra maneira, considerando-me mais criadora e aberta para transformações. Nessa direção, a relação com a arte vibrava em mim como um fogo que acendia minha capacidade de imaginar. Assim, Ostetto comenta a relação com a arte:

Inscrever a arte no itinerário da formação fará sentido quanto mais puder acender coisas por dentro dos professores. Fogo. Acender a chama. Imaginar. Construir o reino intermediário. Criação, reinvenção, disposição à aventura de viver por inteiro. lluminação ao aventureiro. Incendiar o receituário de resposta. Destruição do que precisa ser renovado. Aquecimento da alma, (in)justamente desprezada por uma educação racionalista e pragmática. Entregar-se à beleza. (p. 236, 2006)

Durante a experiência com o campo artístico, onde encontrava uma entrega para vivenciar a beleza, procurei buscar novas possibilidades de atuação na vida e em meus trabalhos. Compreendo que o caminho não era diretivo, não aprendia no teatro situações para promover em sala de aula. Por outro lado, aquela relação ressoava em minha existência, uma professora mais questionadora, ativa e capaz de buscar novas práticas educativas. Aceitava que o campo da Arte/Educação me revelava inquietudes e questionamentos acerca das práticas educativas voltadas para a sala de aula; ainda mais nesta situação, pois as aulas de artes plásticas não eram confortáveis. No entanto, era um desejo inquieto que permeava minhas buscas como professora. Incorporar essa inquietude ajudava a recriar minhas práxis. Esse cenário, ao mesmo tempo, movia-me a sair dessa condição e buscar novos elementos para realizar o trabalho de forma consistente. Essa busca coloca um outro aspecto da formação docente em movimento. O professor pesquisador não vai se conter apenas com a formação universitária, embora ela seja fundamental. Contudo, a práxis docente deve promover questionamentos que nos coloquem em uma constante pesquisa por conhecimento e aprendizagens.

Começo o segundo semestre de 2014 com essa premissa. Perguntava a mim mesma como auxiliar as crianças para que potencializassem suas escritas e pesquisas relacionadas às demais áreas do conhecimento. Toda semana, íamos à biblioteca retirar um livro e fazer indicações literárias. Uma criança levantou na roda uma questão a respeito do surgimento do universo. Durante a roda de conversa, ela passou a questionar sobre a origem da vida e como todas as coisas foram surgindo.

No segundo semestre daquele ano, minha sala contava com 25 estudantes e praticamente todas e todos já tinham completado 6 anos. Eram muito questionadoras e questionadores. Eu procurava atuar para que pudessem ter espaços de reflexão em suas indagações, para falar sobre si, sobre suas preferências e buscas. As rodas de leitura foram vivências fundamentais para o desenvolvimento desse aspecto. $\mathrm{O}$ momento de falar sobre a história era um momento de muita concentração. Primeiro, deixava um tempo em aberto para quem quisesse falar sobre o livro que acabara de ser lido. O gosto por terem um espaço de fala foi tomando conta do grupo, e todas e todos falavam. A roda era enorme, 25 crianças falando sobre o que tinham lido, sobre o que mais gostaram e qual colega iria adorar ler o livro. Nem sempre era tranquilo, havia dias de muita agitação, mas ainda assim era possível realizar a atividade. Aprendi a conviver com alguns momentos difíceis e, nesse sentido, acho que fui deixando de querer controlá-los o tempo todo. Acredito que esse não controle construiu em mim e neles uma possibilidade de comunicação de outra natureza. O corpo também falava, também queria expressar-se. Em alguns momentos, quando percebia uma agitação maior, sentia que não podiam ficar sentados esperando sua vez de falar. Eu, então, deixava que pudessem deitar e mesmo trocar de lugar.

Algumas situações singulares revelavam-me um aspecto muito afetivo conquistado pelo grupo. Parte das crianças já estava lendo em letra de imprensa e outras ainda não tinham conseguido ler com autonomia a letra bastão. Às vezes, as indicações literárias eram feitas pelas crianças no sentido de apoiar os colegas em seus desafios, como, por exemplo, a indicação de um livro em letra bastão para um colega treinar a leitura. As perguntas decorrentes nas rodas de leitura instigavam-me a pensar um caminho que pudesse ser interessante para, dessa forma, construir um projeto que trabaIhasse o conhecimento de forma multidisciplinar. Pensando na melhor forma de responder a essas questões, na tentativa de não dar respostas prontas, fechadas, e observando o interesse de algumas crianças em procurar livros na biblioteca que abordavam questões mitológicas, decidi utilizar títulos que traziam mitos em seu repertório. Comecei a trabalhar com a trilogia Divinas Aventuras, Divinas Desventuras e Divinas Travessuras de Heloisa Pietro ${ }^{16}$. Os livros narram histórias, aventuras e desventuras dos mitos heróis gregos, assim como o nascimento e o surgimento de deusas e deuses.

16. Os livros: Divinas Aventuras: outras histórias da mitologia grega, 1997; Divinas Desventuras: outras histórias da mitologia grega 2009 e Divinas Travessuras: mais histórias da mitologia grega, 2012. Foram publicados por PIETRO, Heloisa, Companhia das Letrinhas, São Paulo. 
A Terra, por exemplo, nessa perspectiva literária, pode ser vista como uma deusa chamada Gaia. Eu acreditava que esses títulos poderiam ampliar as indagações produzidas pelos alunos, como também, expandir o imaginário em relação ao surgimento das coisas. A leitura passou a despertar diversos interesses e novos questionamentos foram colocados.

Passamos a criar produções de escrita sobre o que estávamos descobrindo e a literatura foi uma escolha para tentar responder e ampliar as perguntas. Esse despertar abriu possibilidades para outras situações fora da sala de aula. Era bastante recorrente observar as crianças, durante o horário do parque, fazendo pesquisas nos computadores da biblioteca, que ficava aberta durante todo o dia, disponibilizando computadores com internet para que os estudantes pudessem realizar suas investigações.

Em uma outra roda de biblioteca, um estudante perguntou sobre o surgimento das cores e um colega respondeu por meio de uma análise pautada por uma lenda indígena mexicana. Na semana anterior, ele lera $A$ história das cores, ${ }^{17}$ livro de autoria do zapatista Subcomandante Marcos. O livro mostra um diálogo entre um chefe indígena e um homem subindo uma montanha. Ao se depararem com uma arara, entramos em contato com uma versão indígena sobre o surgimento das cores. A partir da resposta daquela criança, considerei que minhas alunas e alunos estavam chegando a hipóteses muito interessantes sobre o que estávamos pesquisando. Mais do que criarem perguntas, estavam criando respostas. Foi sendo provocado um espírito investigativo, quase sempre pautando os conhecimentos adquiridos pela literatura para criar perguntas e hipóteses acerca do que estava sendo pesquisado pelo grupo. Algumas questões pareciam-me muito filosóficas: "a origem das coisas", por exemplo, não poderia ser respondida de forma tão simplista. Por isso, sempre busquei não fechar os conteúdos, não os respondendo como verdades, pois queria que meus estudantes pudessem conhecer que há várias formas de se compreender o conhecimento. Comentava que havia abordagens científicas e mitológicas, por exemplo, para se responder a mesma pergunta.

A brincadeira revela diversos aspectos das expressões das crianças, elas se comunicam ao brincar. Passo a observar que, no parque e em situações de brincadeiras não dirigidas, os tecidos transformavam-se em vestimentas dos diversos personagens que apareciam nas narrativas. Sempre deixava disponível alguns materiais não estruturados, caixas, pneus, latas e tecidos, para que pudessem explorá-los da forma como bem entendessem. O que aprendíamos em sala de aula começava a ser teatralizado no parque. Re-

17. O livro A Histórias da Cores é um livro infantil que diz respeito a uma adaptação mitológica indígena mexicana escrita pelo Subcomandante Marcos, uma das principais vozes do comando militar indígena mexicano chamado: Exercito Zapatista de Libertaça Nacional. O livro foi publicado e traduzido pela editora Martins Fontes em 2003.

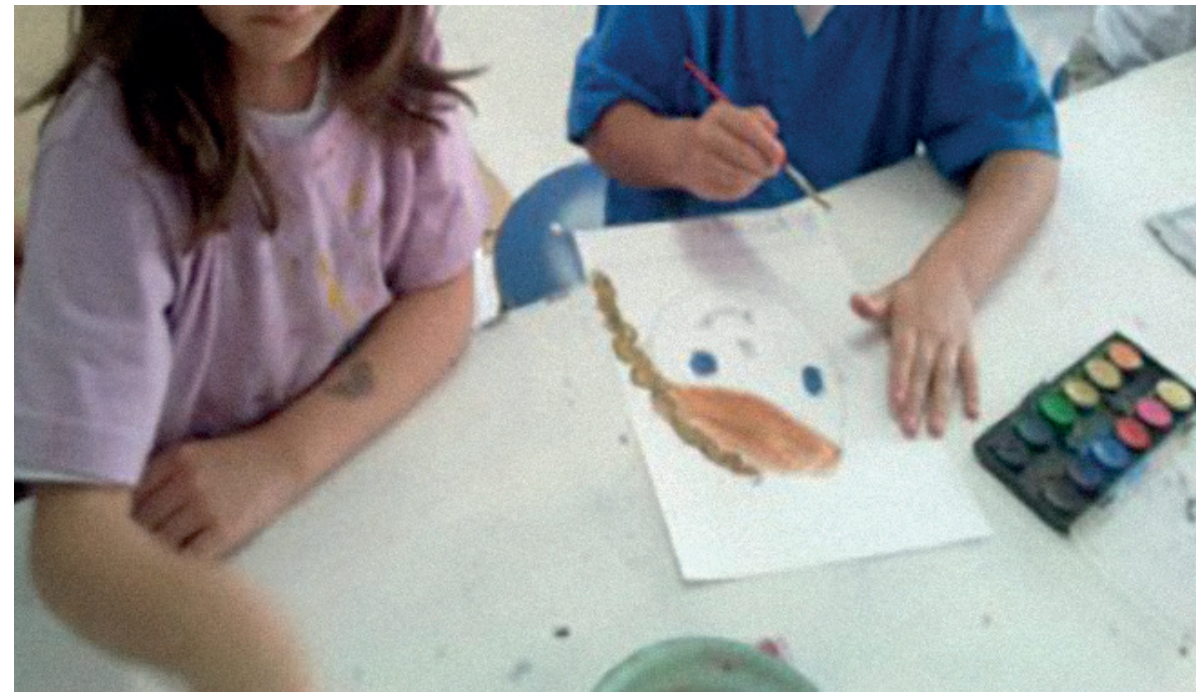

Figura 8. No ateliê de artes, desenho e escrita com lápis grafite e aquarela. A deusa Ártemis assim é narrada pela aluna A. e pelo aluno F., ambos de 6 anos. A proposta foi realizada a partir da leitura do livro "Divinas Aventuras". Foto: Gabriela Mafud, 2014

solvi colocar na rotina um momento para esse tipo de brincadeira: o corpo passa a ser também uma expressão plástica. Os tecidos ganham formas de roupas e cenários. Isso me revelou uma outra maneira de expressão dos conhecimentos conquistados.

Passei, então, a utilizar dessa temática para relacioná-la às outras linguagens que trabalhava em sala de aula. Era uma tentativa de não fragmentar as disciplinas e ampliar a possibilidade de trabalho. Em língua portuguesa, os personagens das histórias serviram para auxiliar no processo de avanço e consolidação da escrita e leitura. Para as crianças que ainda não tinham consolidado o processo de alfabetização, escrever os nomes dos personagens vinha ao encontro de pesquisas sobre as letras. Havia um banco de nomes dos personagens em nosso mural. As crianças escreviam e buscavam nele as referências para confrontarem com suas hipóteses. Para as que já estavam escrevendo algumas palavras, mas que precisavam ampliar seu repertório, outro recurso de avanço para consolidação da escrita foi a elaboração de uma lista de palavras a partir do que os alunos percebiam nas imagens das histórias. Para as que já estavam escrevendo, as imagens ajudavam a desenvolver histórias de sua própria autoria.

Percebia que esse recurso ajudava os estudantes no avanço da escrita e da leitura. Conseguia trabalhar a mesma proposta com intencionalidades distintas, relacionando-a com os desafios singulares de cada criança. 


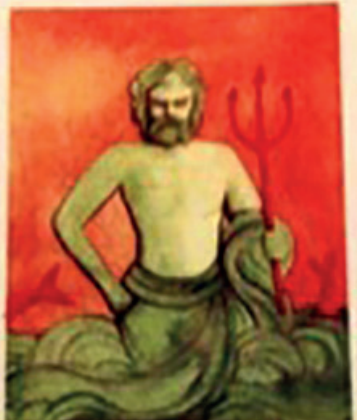

POSEGDON ESTA PALADO AUONAR ELE PODE SE TRANSFORINAR
Figura 9. Escrita tendo como referência a imagem de Poseidon, deus do mar, extraído do livro Divinas Aventuras, de Heloisa Prieto. Escreve o estudante: "Poseidon está parado no mar "Posed e tran parado no mar ele pode se transformar." A mesma atividade foi usada para todo o grupo. Cada criança, no entanto, escreveu suas hipóteses de forma distinta. Algumas escreviam somente o nome do personagem, por exemplo, e outras listavam o que estavam vendo na imagem, 2014.

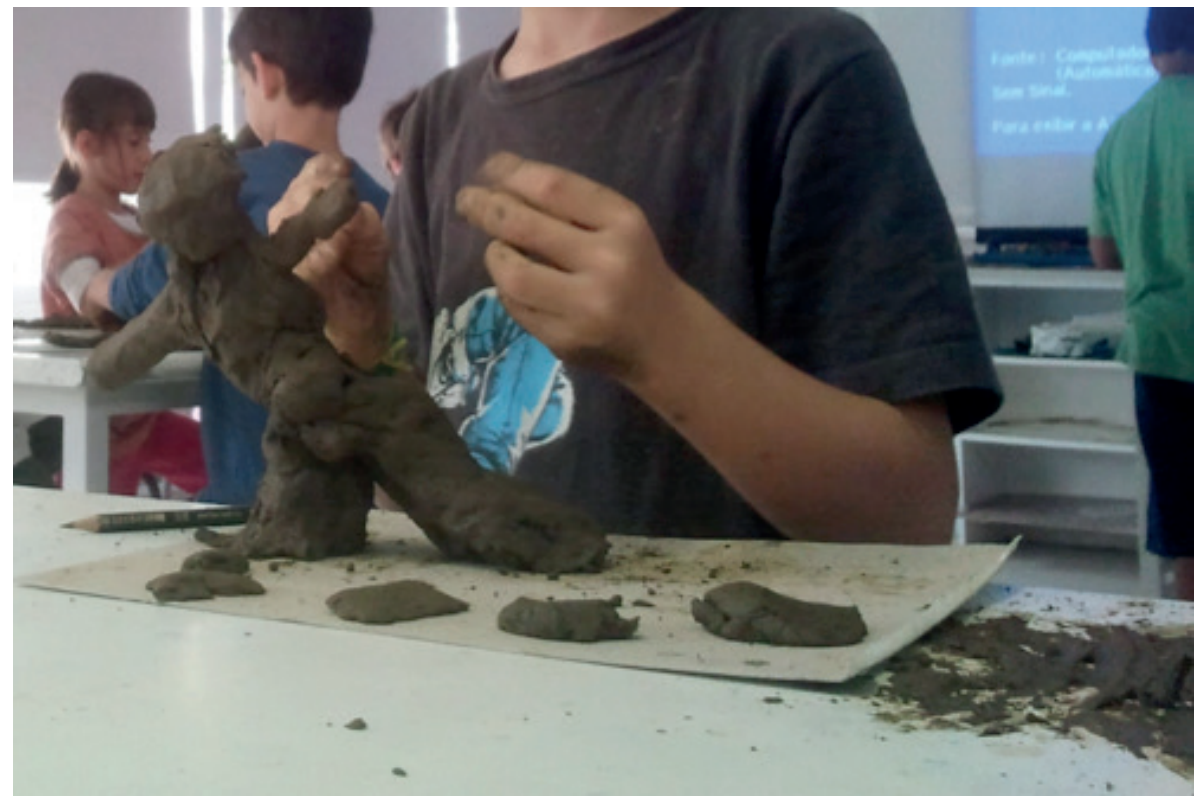

Figura 10. Ateliê com argila. A base da escultura revela a expressão do aluno em relação ao deus Hermes. Coloquei um papelão como base pois, ao testar a argila, antes de oferecê-la às crianças, percebi que ele dava um suporte maior para a escultura.

deixava bastante aflita e não conseguia resolver as questões. Acreditava que se a escola possuísse um forno, tudo estaria resolvido. Hoje, no entanto, compreendo que não seria a melhor forma de resolver o problema mas, naquele momento, acreditava que um forno me ajudaria muito (vejo como parte do processo de formação nos cursos de cerâmica o trabalho com o forno). Aquela associação me parecia óbvia e não encontrei interlocutores que pudessem me auxiliar. Outras possibilidades, contudo, foram surgindo.

Naquele ano, também estava atuando em uma peça chamada $A$ peste invade Atenas. Esse processo foi o primeiro trabalho realizado pelo grupo Teatro da Peste. Em 2012, Júlia Burnier ${ }^{18}$ me convidou para participar da montagem de As três irmãs, do teatrólogo russo Anton Tchékhov, para o processo de criação de um trabalho que estava realizando como estudante de habilitação de direção no curso de Artes Cênicas na Escola de Comunicações e Artes (ECA) da USP. Aquela experimentação nos entusiasmou e decidimos fundar o grupo Teatro da Peste, assim chamado pois, "antes de mais nada, [é] importante admitir que, como a peste, o jogo teatral seja

18. Júlia Burnier é formada em Artes Cênicas pela ECA/USP com habilitação em direção Atualmente desenvolve trabalhos como atriz e é professora de teatro para crianças e adolescentes. 


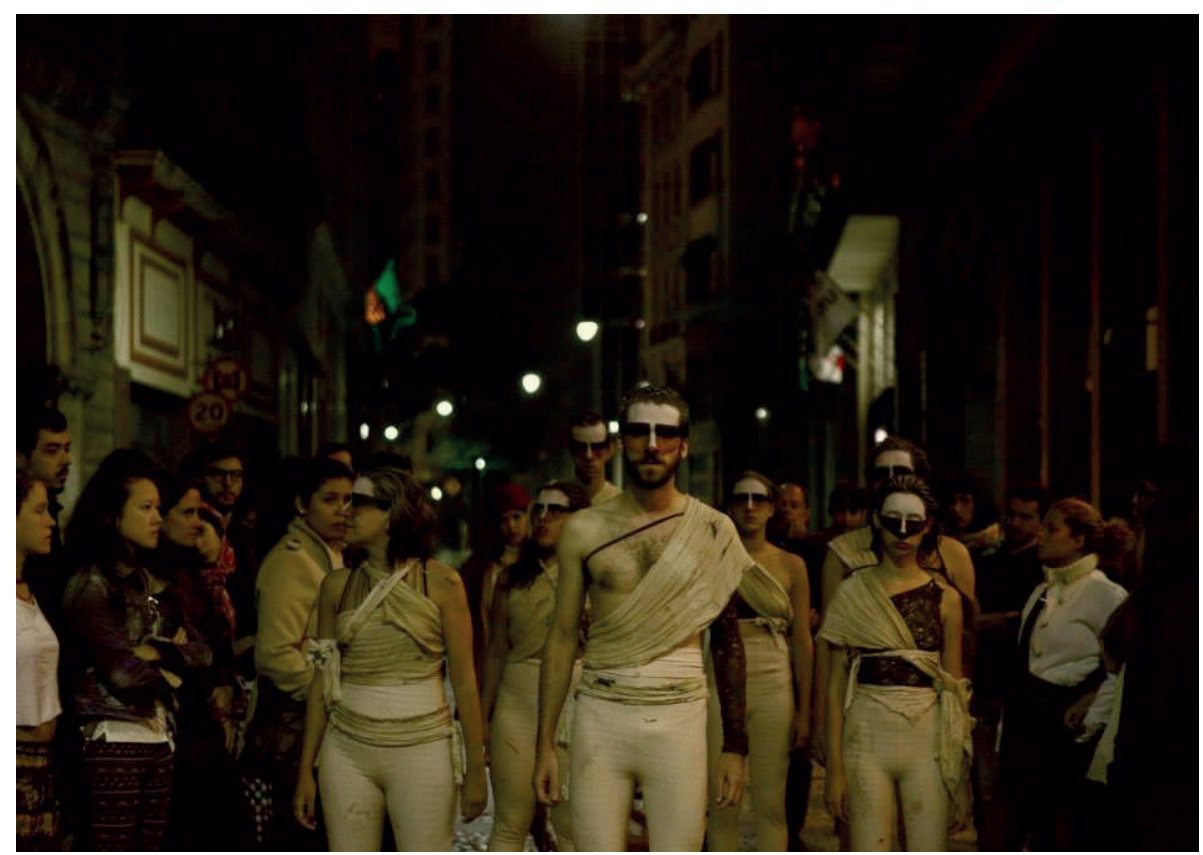

Figura 11. Coro ateniense em "A Peste invade Atenas". Foto: Luiza Telles. Centro velho de São Paulo, 2014

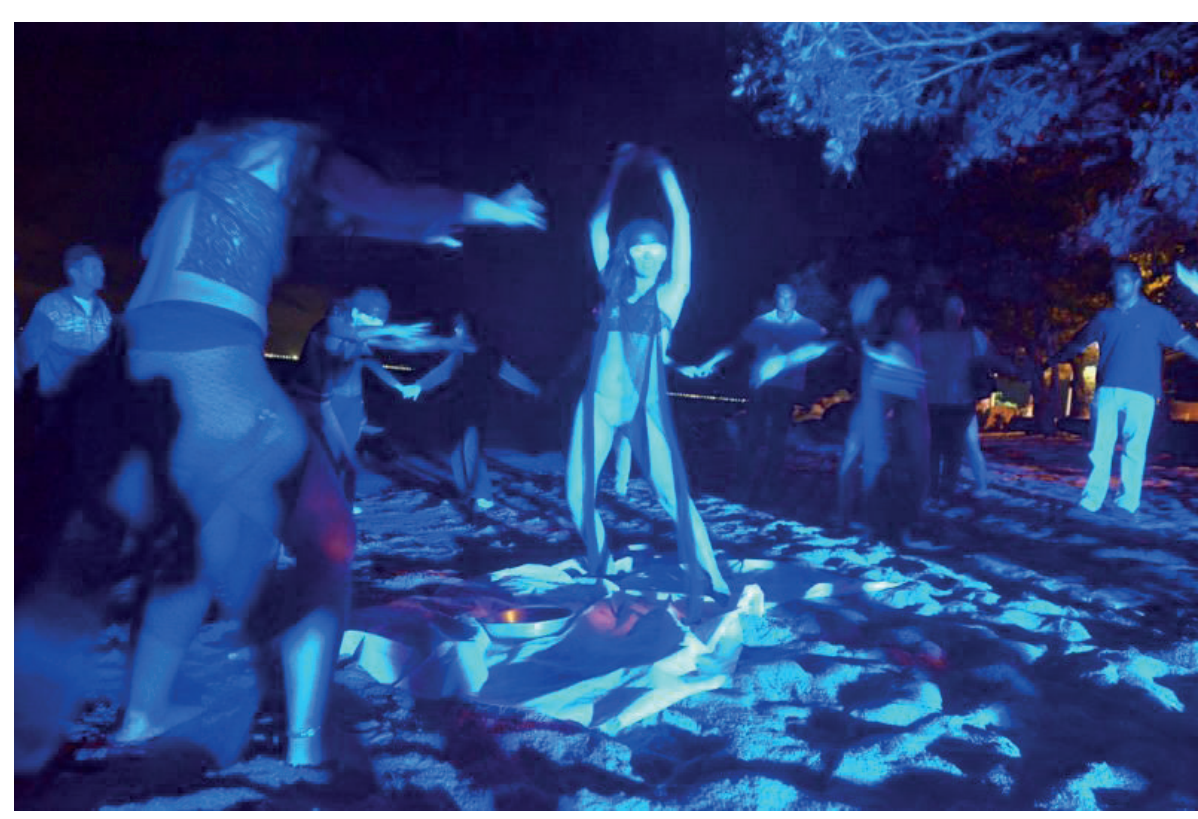

Figura 12. Cena do ritual de Parsifae, rainha de Creta, personagem que atuei em "A peste invade Atenas". Foto: Júlia Burnier. Festival de Teatro de Florianópolis, 2014.
Sempre comentava com as crianças o meu trabalho no teatro. Havia, inclusive, contado a elas algumas aventuras mitológicas que a peça trazia como, por exemplo, a história do Minotauro. Quase que em um processo simbiótico, minhas alunas e alunos passaram a querer fazer teatro. Os universos eram próximos: estava atuando em uma peça cujo tema era a Grécia antiga e, em sala de aula, investigávamos a própria temática da mitologia grega. Eu me perguntava como conseguiria pôr em movimento esse desejo. A princípio, relutava com a ideia de criar uma apresentação teatral com crianças pequenas, mas o desejo era tão grande que passei a aceitar a ideia e a trazer elementos do teatro para que pudéssemos avançar com uma pesquisa consistente. Queria contextualizar a história do teatro, mostrar imagens da arquitetura de alguns teatros antigos e modernos. Fiz uma apresentação contando que o teatro ocidental nasceu na Grécia, mesmo país dos personagens de nossa história. Conhecemos, então, Dionísio, semideus criador do teatro ocidental.

Aproximar esse universo de outros conteúdos e, assim, trazer uma perspectiva multidisciplinar para o conhecimento foi outro desafio. Lançava mão, por exemplo, das histórias e da temática para compor uma proposta de problemas para as aulas de matemática.

Os caminhos foram se alongando: novas divindades de outras culturas, como os mitos iorubás, também foram compondo nosso imaginário. Li com as alunas e alunos alguns títulos de Reginaldo Prandi, como Ifá, o adivinho e Xangô, o trovão, por exemplo. Queria ampliar o repertório literário e não utilizar apenas uma perspectiva eurocêntrica. Nosso desafio agora era começar a peça teatral, definir os personagens, criar os figurinos e cenários. Acreditei que a melhor forma seria dividi-los em dois grupos. Um grupo teria 12 crianças e o outro 13. Fiz questão de mesclar as meninas e os meninos. As crianças que já tinham consolidado suas hipóteses de escrita - e naquele momento grande parte do grupo já estava alfabético - seriam as escribas.

Contava com a ajuda e o apoio de Leonardo Golode, meu auxiliar de sala. Nas aulas de Língua Portuguesa, escrevíamos o roteiro. No ateliê, experimentávamos possibilidades cênicas na construção dos cenários e figurinos ao trabalhar com objetos tridimensionais. Primeiro, realizávamos os projetos no papel em forma de desenho; os cenários e figurinos saíam em seguida do papel para ganhar uma outra materialidade.

A escrita da peça teatral deu-se em outubro. Trabalhávamos um pouco nela todos os dias, pelo período de duas semanas. Fizemos uma espécie de roteiro para auxiliá-los na escrita; primeiro, eles negociaram os personagen que iriam aparecer, depois, o cenário e o conflito da história. O primeiro grupo trouxe os mitos na infância, como estudantes de uma escola. Acontecia um conflito entre eles e as professoras os ajudavam a resolver. Uma das crianças, a deusa Atena, construíra uma máquina que criava novas pessoas 


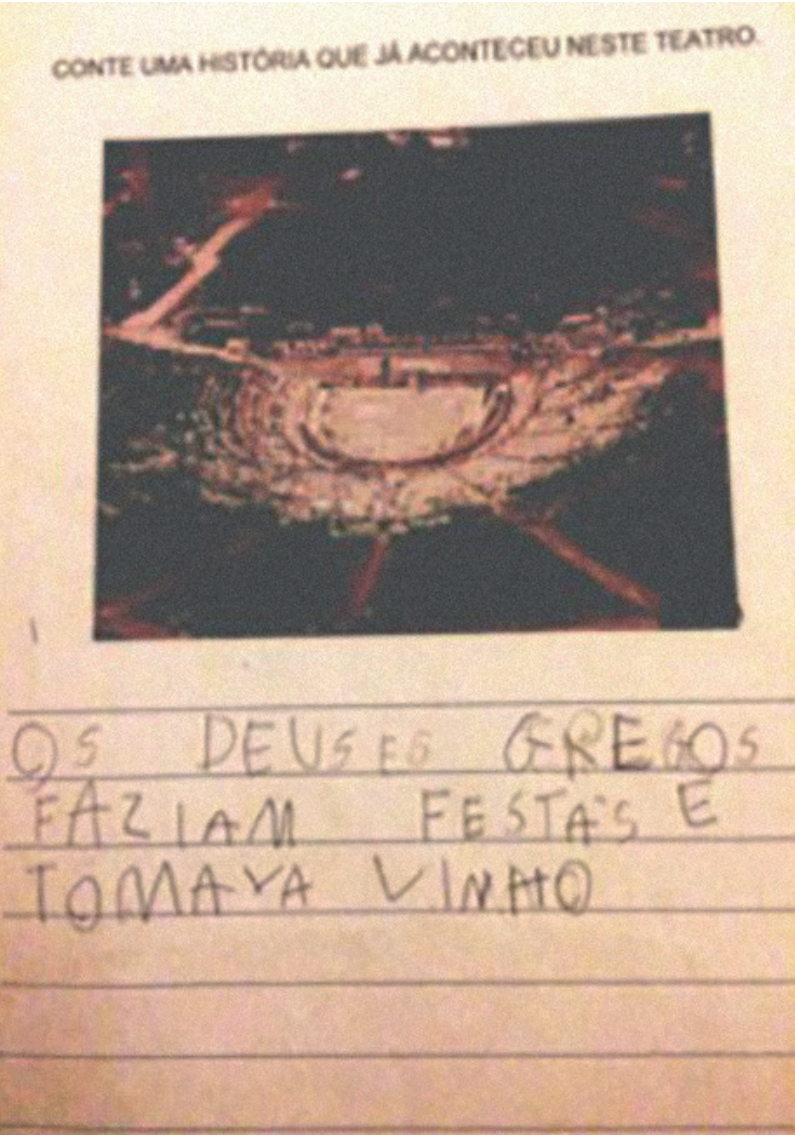

Figura 13. Imagem de arquivo pessoal do Teatro de Dionísio ocalizado na cidade de Atenas. Proposta de Atenas. Proposta de escrita a partir dos conhecimentos pesquisados sobre teatro, 2014.

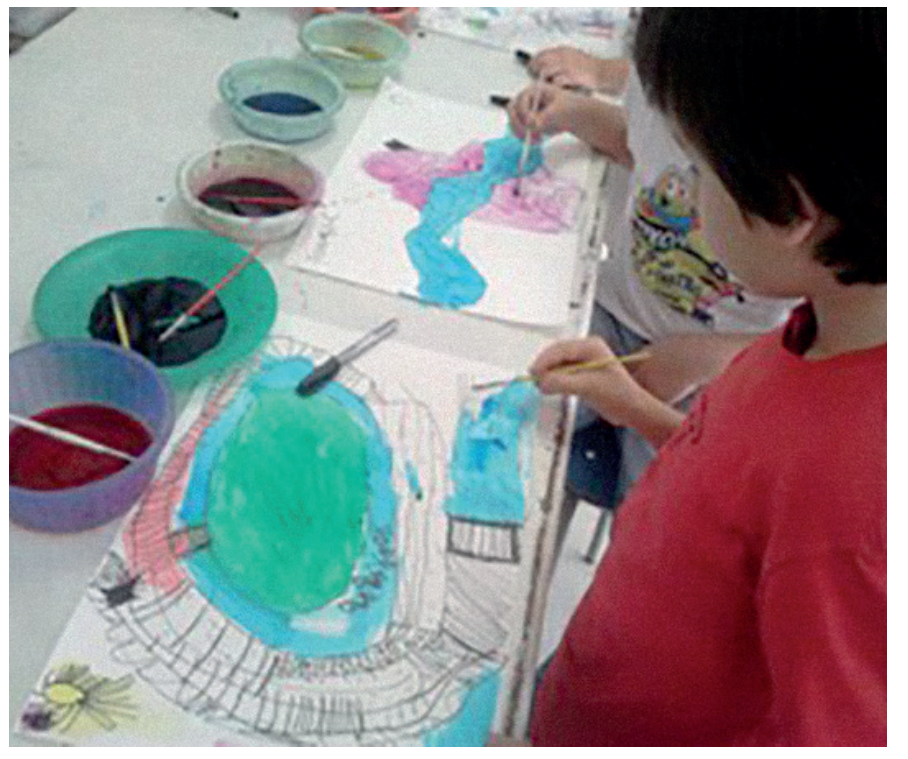

Figura 14. Criação a partir de imagens arquitetônicas de alguns teatros, cada criança escolheu um teatro da sua preferência. A primeira imagem revela um teatro de arena, a segunda o Teatro Oficina, 2014.

\section{WTOSE TEATRE}

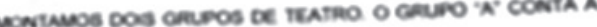

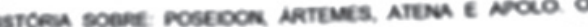

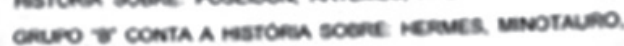

- auresursecromos

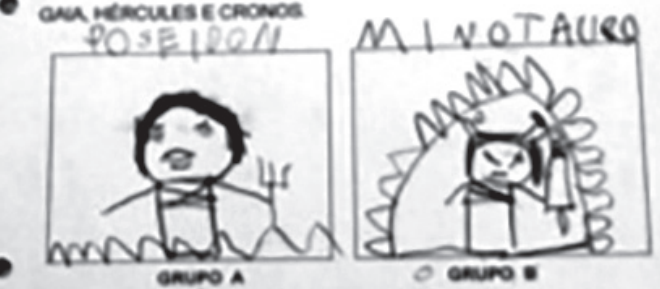

\section{"S PEtsonAGEl(KS}

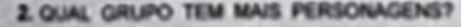

OQRVTO 8

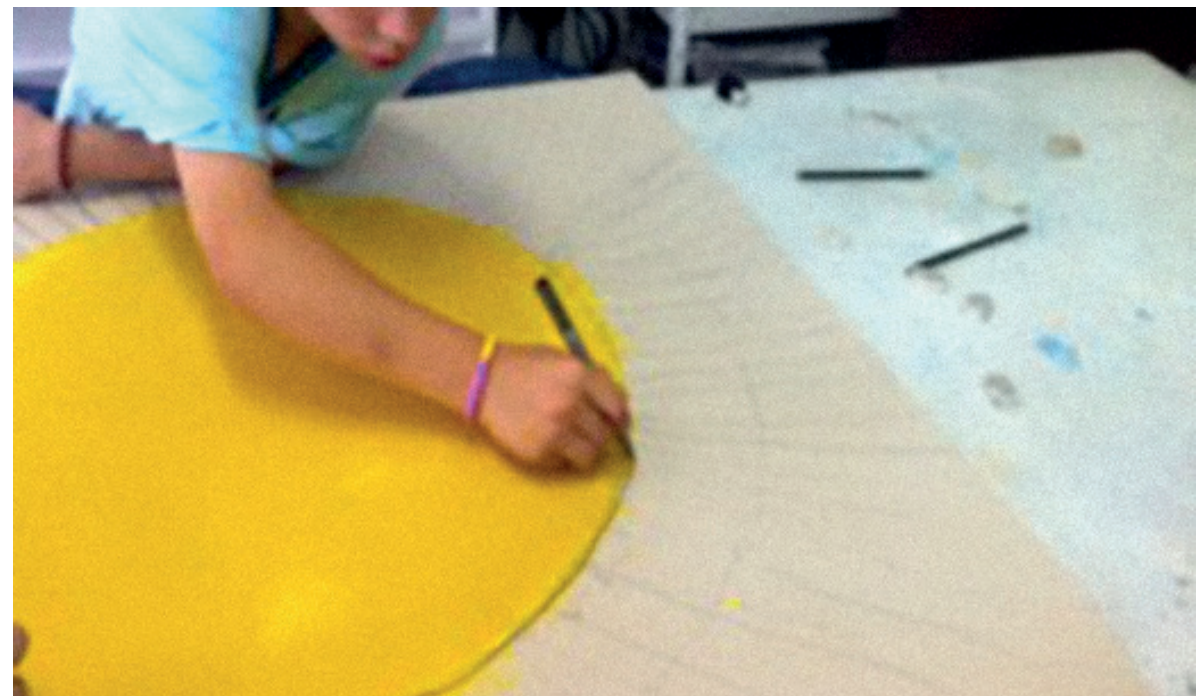

Figura 16. Aluno criando o escudo de Apolo, deus do Sol. Nessa proposta os estudantes estavam debruçados em criar os elementos cênicos de seus personagens. Mesmo aqueles que não encenariam como atores teriam seus figurinos e elementos cênicos, 2014. 
mas, em uma brincadeira, os colegas acabaram quebrando a "máquina". Mais uma vez, com a ajuda das professoras, tudo terminava bem. Achei muito interessante essa escolha: as crianças utilizavam os personagens míticos para representar situações bastante comuns no dia a dia da escola. O outro grupo optou por narrar como os deuses foram nascendo e, além disso, trouxe mitos e divindades de culturas distintas. Segundo o roteiro, Gaia, a mãe da terra, resolve viajar para o Brasil a fim de conhecer deuses e deusas afro-brasileiras. Namora, fica grávida, e daí nasce lemanjá, a deusa dos mares.

O processo de escrita foi bastante desafiador. Além de conseguirmos administrar os conflitos e desejos dos estudantes nos grupos, era difícil pensar nas intervenções necessárias na escrita sem tirar a autoria das crianças. Algumas alunas e alunos não estavam muito interessados em discutir questões referentes à escrita. De modo geral, todas e todos contribuíram para a criação, narrando seus desejos. No entanto, escrever foi outro desafio. Optei, então, por trabalhar essas questões com os estudantes que estavam mais envolvidos com esse momento da escrita. Cerca de seis crianças já produziam textos longos e começavam a se preocupar com questões relacionadas à pontuação, à textualidade e à gramática. A maior parte do grupo estava alfabética, apenas duas crianças estavam em outro momento. Procurei respeitar o tempo, os desejos e as buscas de cada um. Nesse sentido, não adiantava em nada trabalhar essas questões com as crianças que ainda estavam buscando outras formas de pensar a escrita. $O$ importante era garantir um espaço para todas e todos.

Passamos a ensaiar a peça de forma bastante espontânea. Algumas crianças não quiseram atuar. Sentiam vergonha ao se expressar dessa forma na frente dos demais. Atuar na peça como ator e atriz não era um desejo de todos, mas fazer teatro era uma unanimidade no grupo. Fomos, então, pensando coletivamente uma forma dessas crianças estarem na peça. Discutimos que, no teatro, há vários papéis estabelecidos e que não existem apenas atrizes e atores: há pessoas encarregadas de criar os sons, os cenários, diretoras e diretores, e até mesmo aqueles que narram o espetáculo. Dessa forma, alguns papéis foram divididos de modo que todas e todos pudessem participar. Ao mesmo tempo, o ateliê era nosso centro de construção, com os figurinos e cenários sendo constituídos naquele espaço.

Esse processo de criação aconteceu até meados de novembro quando, enfim, apresentamos a peça para os familiares. Hoje, relembrando esse processo, percebo que o diálogo com a arte, sobretudo com o teatro, revelou uma maneira de intensificação de aprendizagem enorme naquelas crianças. É muito comum reencontrá-las e recordar o que vivemos. As aprendizagens não ficaram restritas apenas às intencionais para aquela faixa etária. Além dos conteúdos das disciplinas que transitamos, abordando aspectos literários, desenvolvimento da escrita e leitura, outras aprendizagens foram constituídas. Elas transbordaram para além, ocuparam um lugar

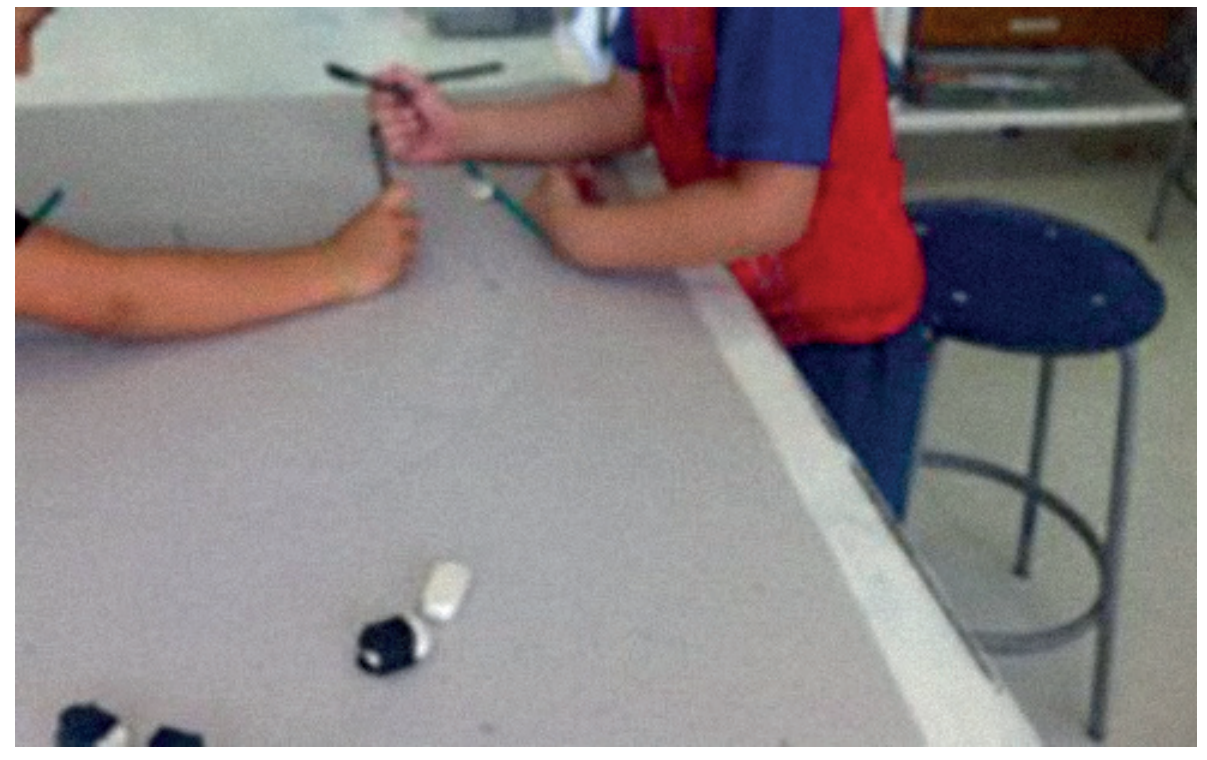

Figura 17. Dupla criando o relógio do deus Cronos. Proposta de criação dos elementos cênicos da peça, 2014.

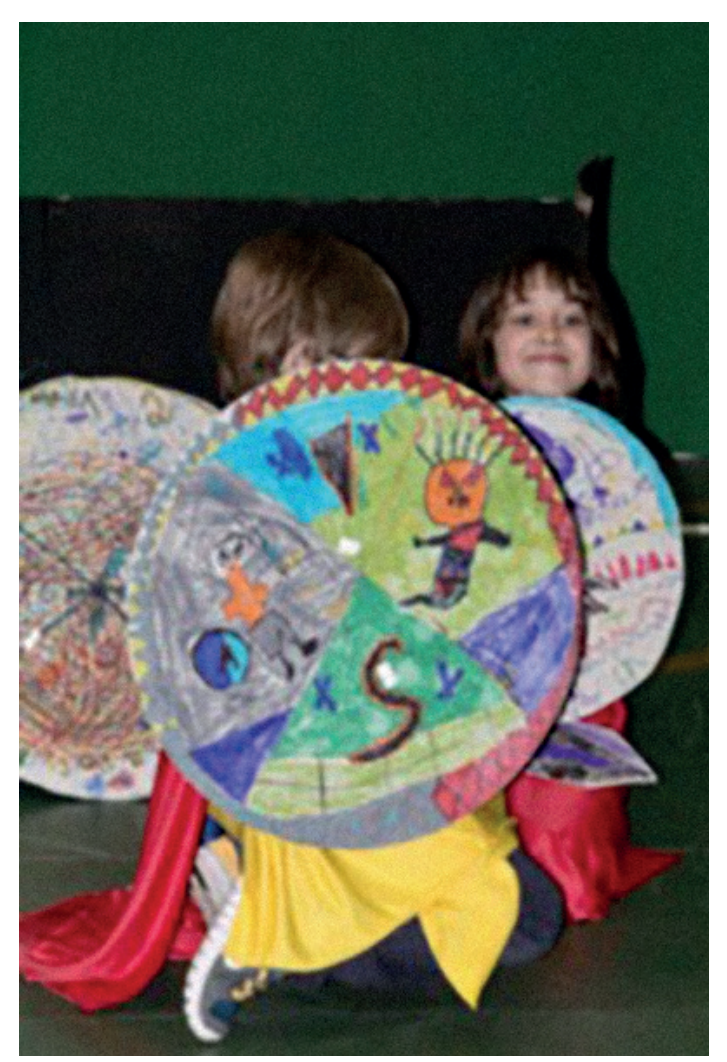

Figura 18. Atores encenando com os elementos cênicos e figurinos criados por eles. Foto: Marcelo Schmiliver, 2014 


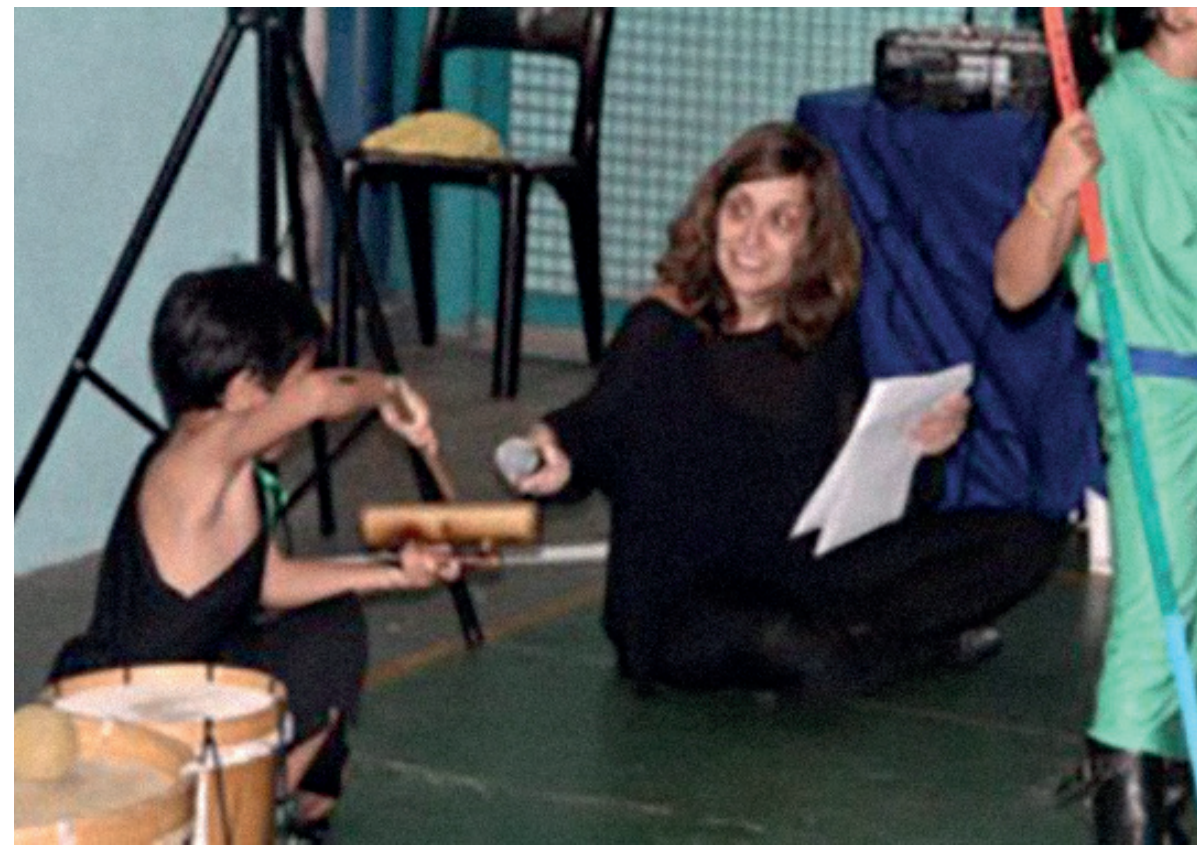

Figura 19. Crianças como músicos e sonoplastas, 2014.

mais sensível do conhecimento, revelando a capacidade de falar sobre si e suas preferências, a busca pela expressão do desenho, do corpo, da fala, e a busca pelo trabalho coletivo, o olhar para o outro e o respeito pelas singularidades. Passou a ser mais habitual percebê-los conscientes do que eram capazes de realizar sozinhos e do que ainda precisavam de ajuda. A possibilidade de novas descobertas permeadas pelo campo da arte-campo aberto de possibilidades distintas e realizações de acontecimentos - possibilitou autorias distintas e criações originais de seus percursos.

\subsection{O TEMPO E SUAS POTÊNCIAS}

Atualmente, trabalho como professora de artes (artes plásticas, teatro, corpo e brincadeira) na USINA (Unidade Semi-Integral de Intensificação em Arte), no Colégio São Domingos. ${ }^{19} \mathrm{O}$ trabalho me faz sentir provocada para refletir sobre esse universo com mais profundidade. Encontro desafios enormes nessa atuação. Apesar de ser um desejo profundo, atuar como professora dessas linguagens é um processo que não está isento de dúvidas e de indagações sobre como realizar essas práticas. Nem sempre são situações assertivas ou um trajeto seguro. Mas sigo buscando, testando e me deslocando para construir possibilidades com materiais diversos, registrando minhas práticas, duvidando sempre e me colocando em movimento ao lado dos estudantes.

Há quatro anos, tenho pensado sobre situações em aula nas quais crio espaços como possibilidades de acontecimentos. Para que isso aconteça, me aproprio de materiais não estruturados como caixas, tecidos, retroprojetor e cubos para ambientalizar os espaços de trabalho. Nesses momentos, deixo que as crianças construam seus percursos educativos, criando suas possibilidades e vivências nesses espaços de acontecimentos. Elas expressam seus saberes a partir da relação com os materiais, criando narrativas e situações. Diante dessas proposições, atuo apenas como espectadora, como observadora, e procuro não intervir. Faço apenas registros, reflexões, fotografando as relações com os corpos pulsantes que as crianças apresentam nesses momentos. Esses acontecimentos são substâncias importantes e me revelam como minhas alunas e alunos vão construindo seus percursos e as relações que vão estabelecendo de forma singular e autônoma.

Aprendo o quanto há dessa tal característica artista-arteira em suas expressões. Na relação com a simplicidade dos materiais, criam universos fabulosos, cênicos, teatrais, visuais e brincantes. As crianças são criadoras de cultura, de expressão, de linguagem, de relações consigo mesmas e com os outros. É daqui que incorporam personagens, vivenciam suas narrativas e suas perguntas pessoais. Internalizam as aprendizagens, transitam entre o que experimentam a partir da realidade posta e com o que são capazes de imaginar. Há momentos de vazio, de ruptura, de silêncio, escuta e olhar. São processos que os constituem enquanto sujeitos de corpos coletivos. Isso tudo me constrói como educadora, me provoca a sair do controle, de deixar acontecer, de me observar enquanto professora propositora de possíveis buscas em mim e em meus estudantes.

19. O Colégio São Domingos foi fundado na cidade de São Paulo, no ano de 1959. Em 2014, foi criada a USINA (Unidade Semi-Integral de Intensificação em Arte) no colégio e, desde então, sou professora das linguagens teatrais, visuais, corporais e brincantes. 


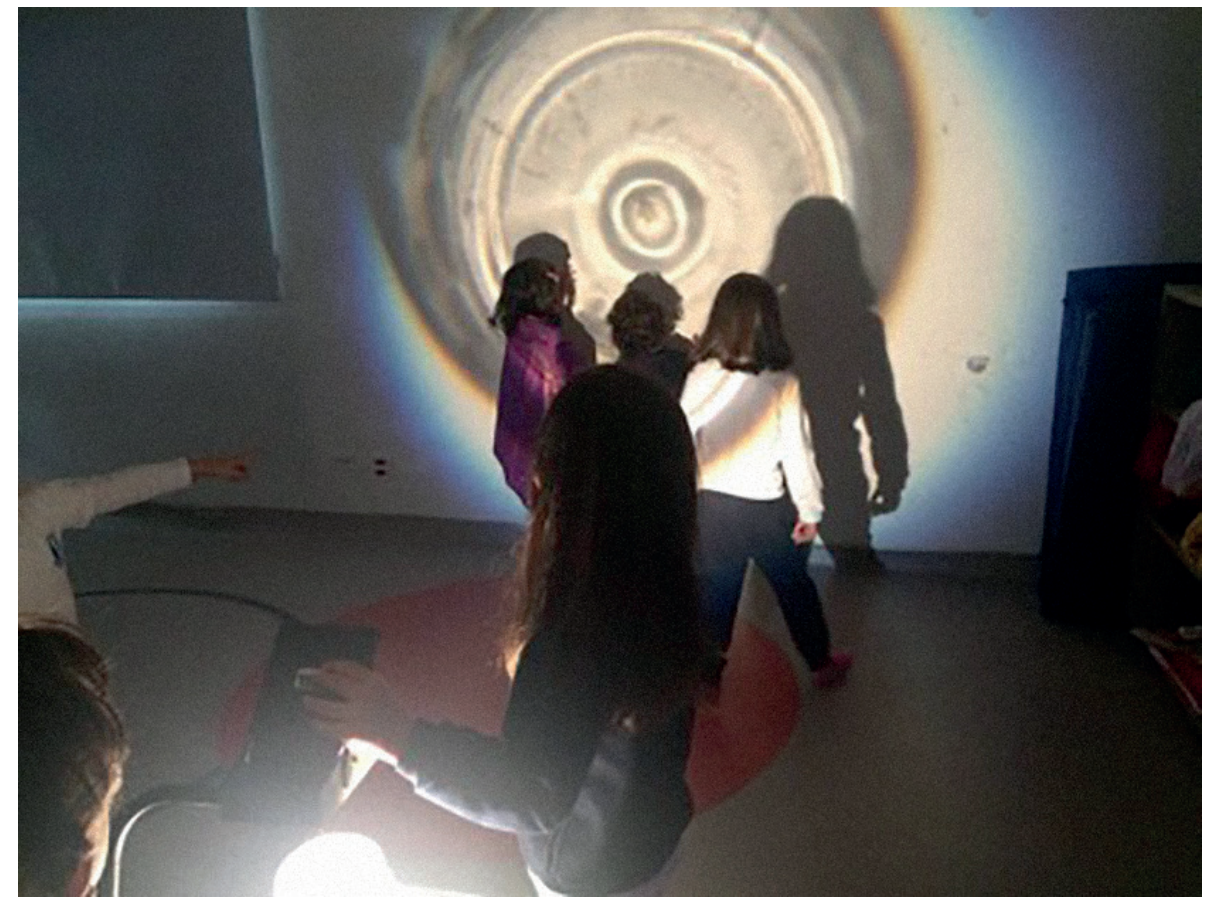

Figura 20. Proposições de ensino: "A criação de espaços como possibilidade de acontecimentos". Crianças realizando situações de expressões do corpo a partir de suportes como: tecido, bolas de gude e retroprojetor. Foto: Gabriela Mafud, 2018.

São essas situações que nos fazem estar atentas aos mínimos detalhes de comunicação, nem sempre clara, de nossas alunas e alunos.

$\mathrm{Na}$ escuta ativa com nossos estudantes, com nosso tempo, suas contradições e potências, e na busca constante em nos transformarmos e indagarmos sobre nossas práticas educativas, encontramos nas crianças uma fonte viva e pulsante para impulsionar o pensamento crítico. Dessa forma, somos capazes de reconhecer as dificuldades de nossa profissão e, também, pensar caminhos possíveis para o encontro de uma nova realidade.

Há inúmeras possibilidades de se desenhar os percursos educativos das crianças. Aqui, faço um recorte e me volto ao que Carlos Drummond de Andrade escreve em $A$ educação do ser poético. O grande poeta brasileiro, em um artigo para o Jornal do Brasil de julho de 1974, nos indaga: "Por que motivo as crianças, de modo geral, são poetas e, com o tempo, deixam de sê-lo?"20 do Brasil no ano de 1974.
Atualmente, acrescentaria que, além de poetas, são também artistas-arteiras. Como professora e atriz, há mais de dez anos na Educação Infantil e Ensino Fundamental I, em diversas escolas na cidade de São Paulo, absorvo nas crianças a experiência da sensibilidade. Essa experiência está localizada no modo como esses seres se relacionam como o mundo, com a forma de expressar seus sentimentos, suas vivências, suas aprendizagens e descobertas.

As crianças constroem de forma bastante criadora seus percursos, reinventam os saberes que, na escola, são direcionados para alguns aspectos específicos que, muitas vezes, as tolhem de suas expressões originais. No entanto, são frequentemente construtoras de novas possibilidades. Geralmente, são novas dimensões do real que, nas mãos das crianças, ganham uma dimensão de outros imaginários. Assim, Walter Benjamin, em suas Reflexões sobre a criança, o brinquedo e a educação, percebe a capacidade criadora das crianças diante dos detritos:

(...) É que crianças são especialmente inclinadas a buscarem todo local de trabalho onde a atuação sobre as coisas se processa de maneira visível. Sentem-se irresistivelmente atraídas pelos detritos que se originam da construção, do trabalho no jardim ou na marcenaria, da atividade do alfaiate ou onde quer que seja. Nesses produtos residuais reconhecem o rosto que o mundo das coisas volta exatamente para elas, e somente para elas. Neles, estão menos empenhadas em reproduzir as obras dos para elas. Neles, estão monos empenhadas em reproduzir as obras dos chaltos do que estabelecer uma relação nova e incoerente entre esse estos e materiais residuais. Com isso as crian ças formam seu próprio mundo inserido no grande". (2002, 57 e 58)

Inclinadas a formarem seus próprios mundos, as crianças vão nos dando pistas dessa formulação. Nós, professoras e professores, em relação ativa - presentes e aprendizes desse novo mundo -, coletamos seus saberes, capturamos seus instantes de criação. Em 2018, durante as aulas de teatro, pesquisava as aventuras de Ulisses, personagem épico que, lançado ao mar, vivencia inúmeras aventuras narradas em a Odisseia. As crianças estavam montando apresentações teatrais a partir dessa história. No entanto, algumas crianças não se sentiam à vontade em criar as peças: ouviam as histórias e eram espectadores de seus colegas. De repente, entrei na sala e capturei uma cena bastante sensível. L., 8 anos, estava aproveitando o vazio do espaço para poder expressar em seu corpo e mente o que aprendera das histórias. Ele geralmente não se colocava no jogo cênico e, quase sempre, permanecia como espectador de seus colegas. Mas, em um desvio, descobrimos suas arteirices criadoras.

Desde o início de minha carreira como professora, venho estabelecendo relações com o campo da arte na prática docente. Esse aspecto me possibilita olhar para minhas alunas e alunos com uma certa amplitude. Não procuro compreender seus percursos formativos apenas pelo que $\circ$ visível me mostra. Busco, também, nos vazios, nas frestas, nos detalhes e 


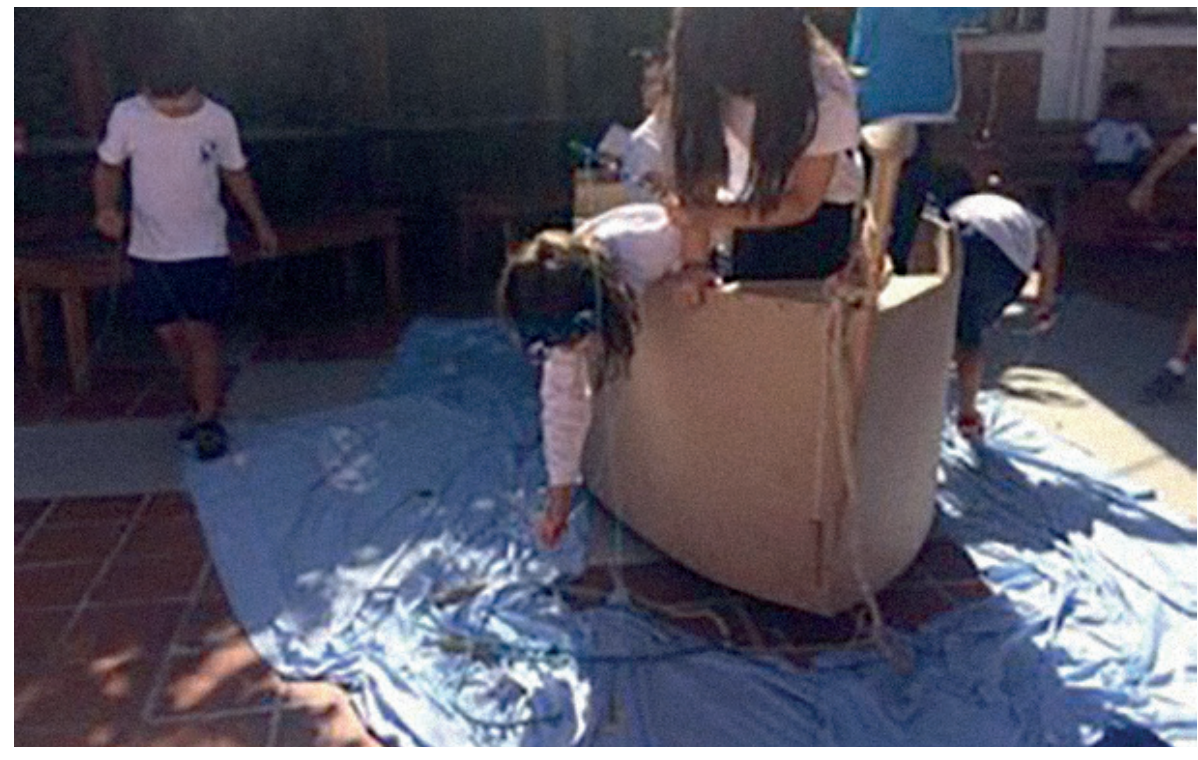

Figura 21. Aula de teatro: com tecidos e pedaços de madeira, as crianças criam narrativas onde seriam navegantes de uma aventura. Foto: Gabriela Mafud, 2018.

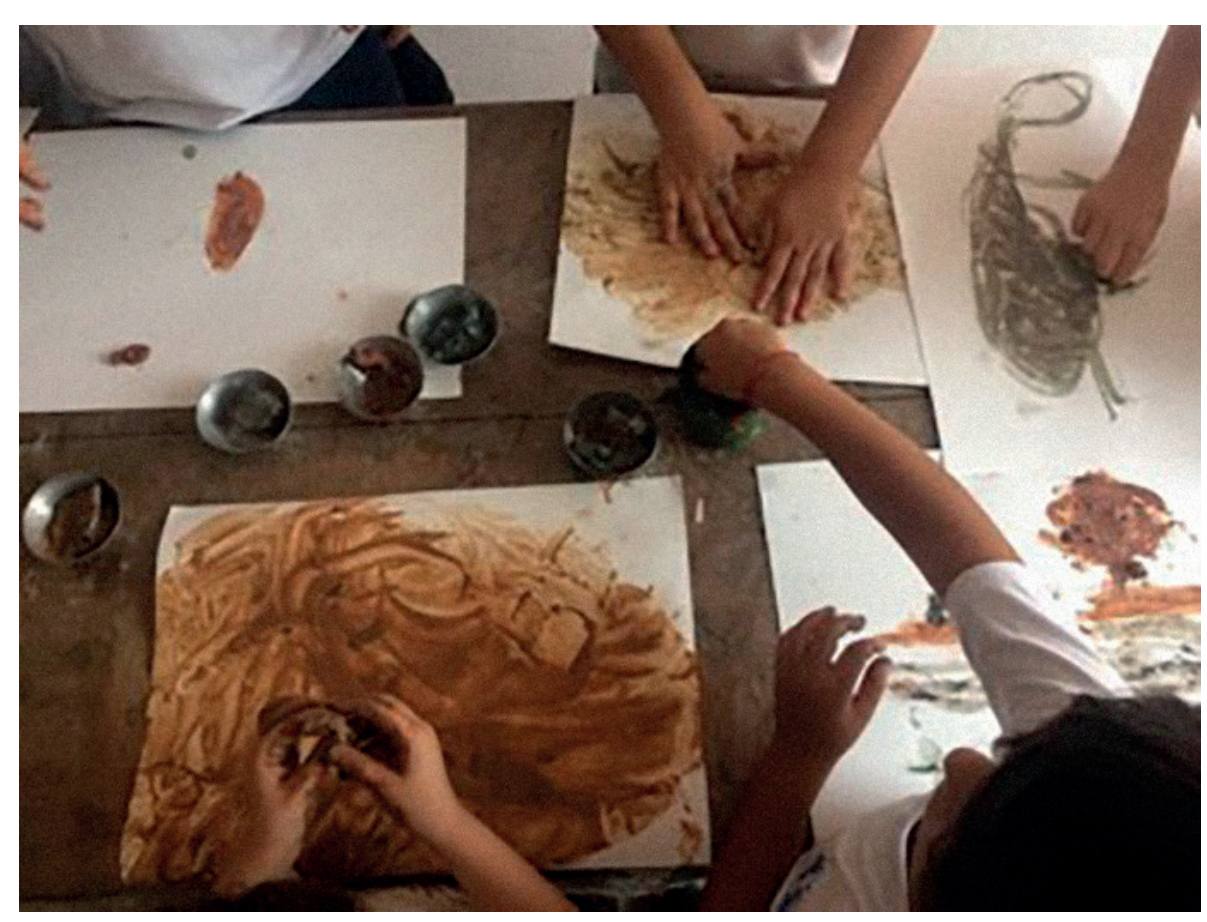

Figura 22. Dos restos de argila, construímos novas possibilidades, criamos texturas, tintas e narrativas. Foto: Gabriela Mafud, 2019 no que está à margem, a maneira como as crianças vão se relacionando com o conhecimento apresentado. A arte, como campo aberto de possibilidades, expande o conhecimento para essas fendas. Nos (trans)forma em professoras e professores criadores, nos auxilia na relação tão inventiva que as crianças possuem e que, ao invés de a tolhermos, como acontece em muitos momentos, sejamos capazes de ampliar as experiências a elas e a nós mesmos.

Dessa forma, encerro o $1^{\circ}$ ato, reconstruindo um processo reflexivo de atuação nos campos da arte, educação e pesquisa. Nomeio-o como "a criação de si". ${ }^{21}$ Ou seja, minhas histórias de vida e formação evidenciam minhas experiências, as dificuldades e buscas para superar a lacuna do campo da Arte/Educação em minha constituição. Inseri-lo na formação inicial de estudantes de Pedagogia seria refletir sobre a possibilidade de um caminho criador na constituição de si e de práticas educativas que possam ser capazes de derrubar fronteiras na sala de aula. É fundamental que os estudantes de Pedagogia possam não apenas pensar em metodologias do campo da Arte, mas que também possam vivenciar experiências das linguagens artísticas em sua formação. Experimentar o ateliê de artes em sua potência criadora, ter a sensibilidade para perceber as possibilidades de um processo de musicalização e de teatralização para trabalhar com seus alunos. A dança como um elemento para perceber o corpo nos diversos espaços educativos que compõem a escola. A arte como válvula potente, ato criador em diálogo com as demais linguagens, pode gerar uma práxis docente criadora. Segundo Sumaya Mattar:

Movimentar-se de forma criadora é conviver com múltiplas possibilidades, levantando e testando hipóteses por meio das quais podem ocorrer modificações que se concretizam em novas formas de pensa e agir. Esse processo não se resume à exploração; permeado que e pela reflexo, gera conhecimento. Assim como o dál pormo, o movimento pe, o movimento humarizaça. En qualquer setor que apareça, inclusive na atter de humanizaça. En qualquer setor que apareça, inclusive na arte e na educação, a práxis inovadora é feita de materiais objetivos e subjetivos, do sonho e da realidade, do possível e do utópico. Esse é o motor da transformação. É ele que faz o ser humano derrubar muralhas, abrir clareiras e habitar o mundo, de fato, por isso, a necessidade de o diálogo e a práxis criadora serem cultivados nas práticas educativas e escolares, incluindo aí as aulas de arte. (2014, p. 95)

21. Neste momento, tomo emprestada "a criação de si" da Profa. Dra. Ana Cristina Rosseto, que em sua tese intitulada "MEMÓRIA E INICIAÇÃO ARTÍSTICA E A CRIAÇÃO DE SI", defendida na Faculdade de Educação da Universidade Estadual de Campinas, 2017, desenvolve reflexões acerca da iniciação artística dentro de uma perspectiva educativa. Relata, dessa maneira, seu percurso como artista-professora na Escola Municipal de passam, assim, a constituir a sua própria criação, ou seja, "a criação de si". 

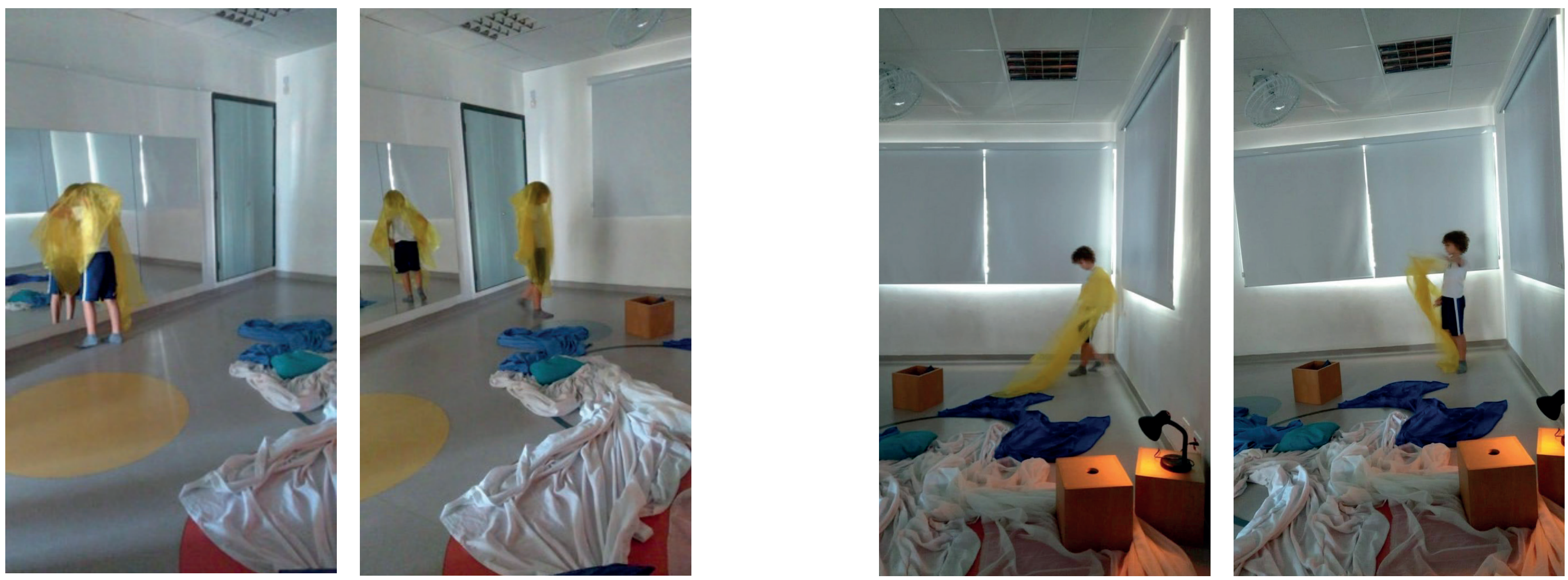

Figura 23. As quatro sequências são imagens que nomeio como Apolo. Após ouvir as histórias narradas em a Odisseia, da qual o deus do sol (Apolo) estava presente, percebo que uma das crianças, ao se ver sozinho, diante de um tecido amarelo, percebo que uma dos crancas, ao se ver sozino, diante de um tecido amarelo, passa a incorporá-lo de maneira inventiva. Cria cenas bastante singulares, sem perceber que estava sendo observado e fotografado por minha antiga auxiliar de sala. Assim, consegue realizá-las com muita destreza. Foto: Ana Carolina Medeiros, 2018.

Considero que vivenciar experiências no campo da arte é justamente possibilitar movimentos de forma criadores, como afirma Mattar. Questionando com maior criticidade nossos caminhos, procuramos diálogo e derrubamos verdades prontas ao perceber e abrir clareiras nas múltiplas formas de atuar na vida. Esse é nosso fator de humanização: perceber diversas formas de experienciar a existência. A arte, como um caminho para alçar voos que permeiam transformações, nos eleva como sujeitos, seres atuantes na história - escrevendo-a, reinventando-a e construindo nossas possibilidades. 
$2^{\circ} \mathrm{ATO}$

AS EXPERIÊNCIAS

DE VIDA E

FORMAÇÃO

CONSTRUINDO

TRAJETOS PARA

A FORMAÇÃO

DE SI 
Depois de relatar minhas experiências no primeiro ato e criar uma cartografia de mim mesma, vou agora relatar as memórias em forma de experiências de vida e formação de quatro companheiras que cruzaram minhas andanças e viagens ao desconhecido pelos campos da Educação e da Arte. Encontro, portanto, ao longo desses mais de dez anos como professora, ressonâncias, afinidades, parcerias, olhares e troca com as colegas. Temos buscas singulares em comum: realizamos a formação inicial no curso de Pedagogia, pesquisamos e vivenciamos experiências na vida e na prática docente cercadas pelo campo da arte/educação. Por isso, considerei importante entrevistar as colegas para ampliar a discussão, elaborar novos pontos de vista e discutir a questão central da pesquisa: como as experiências de vida e formação em arte contribuem para que pedagogas e pedagogos adentrem, em suas práticas em sala de aula, o campo da arte/educação?

Ao compreender a possibilidade de elevar, no campo da experiência, reflexões acerca das práticas em sala de aula inseridas no campo da arte/ educação, tento criar um percurso de entendimento a partir da discussão sobre o lugar da Arte na Pedagogia. Passo a refletir como a formação inicial, somada a outras buscas formativas, contribui com a relação do campo do saber com as vivências pessoais: de se realizar professora, de criar a si mesma, de ir e ser; portanto, de estabelecer o devir professora. É o devir que faz do mínimo trajeto ou mesmo de uma imobilidade no mesmo lugar, uma viagem; o trajeto que faz do imaginário um devir. Os mapas, dos trajetos e dos afectos, remetem um ao outro. Tal qual nos apresenta Gilles Deleuze (2011, p. 88)

Sendo assim, o devir será sempre um ponto de partida, um algo a ser conquistado e impulsionado pelo desejo de ser, ainda que não se tenha totalmente a certeza de que vai chegar ao que levou a sair desse ponto de partida. É o impulso para habitar novos territórios, de se criar novas possibilidades, novos modos de operar nossa subjetividade. Assim escrevem Deleuze e Guatarri:

(...) É nesse sentido que o devir é o processo do desejo. Esse princípio de proximidade ou de aproximação é inteiramente particular, e não reintroduz analogia alguma. Ele indica o mais rigorosamente possíve uma zona de vizinhança ou de co-presença de uma partícula, o movimento que toma toda partícula quando entra nessa zona. $(2012$, P. 62) 
O trajeto formativo é constituído por estes aspectos, abordando situações de movimento, nos projetando a ocupar uma zona que passa pelo real e pelo imaginário. Tanto no que diz respeito à capacidade de imaginar novas possibilidades de existir, de projetar-se, por exemplo, como estudante e como professora, quanto em relação aos aspectos do real. Em muitos casos, a realidade posta nos apresenta novas situações, novas buscas formativas, desenha novos mapas e impulsiona novas viagens ao conhecimento. Criam-se, assim, devires.

Em uma linha do tempo, o primeiro encontro deu-se com Carolina Hamburguer ${ }^{22}$, em 2009. Nos conhecemos nas reuniões do CAPPF (Centro Acadêmico Professor Paulo Freire) na Faculdade de Educação da Universidade de São Paulo. Ela havia acabado de ingressar na universidade e eu estava finalizando a graduação. A empatia foi quase que imediata: naquele ano, organizamos a chapa Parresia para disputar as eleições do centro acadêmico, frequentávamos juntas as assembleias e as festas estudantis. Fomos criando uma afinidade política enorme. As possibilidades de construções utópicas foram marcas muito fortes dessa relação, ela sempre teve um brilho no olhar e uma forma muito apaixonante ao falar das possibilidades de transformações sociais e atuar na escola pública sempre foi seu desejo. Mesmo quando deixamos de nos ver com mais frequência, era recorrente nos encontrarmos em atos e manifestações fora da universidade. Sempre soube da relação de Carolina com o campo da arte, mas não sua profundidade constitutiva. Trazer sua voz nesta escrita é fundamental. Além de toda afinidade política e afetiva, há também buscas bastante comuns, embora singulares, a respeito dos campos da Arte e Educação.

A segunda voz que trago nesta escrita é a de Priscila Fernanda de Brito $^{23}$, colega e parceira desde 2013, ano em que começamos a trabalhar juntas no Colégio Oswald de Andrade. ${ }^{24}$ Nesse ano, eu era professora de

22. Carolina tem 24 anos, formou-se em Pedagogia na Universidade de São Paulo no ano de 2014. Há 3 anos, trabalha como professora da Educação Infantil na EMEI Nelson Mandela. Além de pedagoga, é percursionista do grupo llú Obá De Min (grupo artístico cultural da cidade de São Paulo, desde 2004). Pesquisa as manifestações das culturas de matrizes africanas e afro-brasileiras e é um coletivo de tambores, cantoras culturas de matrizes africanas e afro-brasileiras e e um coletivo

23. Priscila tem 32 anos, formou-se em Pedagogia pela FEUSP em 2013. No mesmo ano, ingressou no mestrado em Sociologia da Educação. É mestre em Educação e defendeu sua dissertação em 2016, com o título "Foi respeitada a expressão da criança quando disse o que fez? - Artes nos parques infantis através das fotografias de Benedito Junqueira Duarte". Há 3 anos, é professora da Educação Infantil e Ensino Fundamental I na USINA (Unidade Semi-integral de Intensificação em Arte) no Colégio São Domingos.

24. O Colégio Oswald de Andrade foi fundado na cidade de São Paulo e tem mais de quarenta anos de existência. Possui os ensinos de Educação Infantil, Ensino Fundamental I e ll e Ensino Médio. uma turma do $2^{\circ}$ ano do Ensino Fundamental I, e ela, professora auxiliar. Tecemos uma afinidade enorme em relação ao olhar que estabelecemos com as crianças e com o mundo em que vivemos. Tínhamos uma turma de 25 estudantes e muitos desafios nos foram apresentados naquele ano. Nos relacionamos com uma sala extremamente heterogênea tanto no que diz respeito às questões de aprendizagem, quanto às questões sociais. Aprender a lidar e a respeitar o momento de cada criança, a forma como elas expressavam suas aprendizagens e relações, tudo isso foi muito transformador para nós. Vivemos muitas intensidades juntas naquele ano. De forma bastante sensivel, Priscila me ajudou com a ampliação de um olhar sobre a produção artística dos estudantes. Muitos dos desenhos e falas de nosso grupo foram fontes de sua pesquisa de mestrado. Continuamos juntas desde então e, atualmente, somos professoras do mesmo projeto; permanecemos atentas às produções das crianças, construindo novas possibilidades de atuar no campo da Arte/Educação, compartilhando desejos, pesquisas e sensibilidades em relação às nossas alunas e alunos. Além de uma grande professora, é também uma pesquisadora convicta a respeito das criações artísticas das crianças: trazer a sua voz para essa pesquisa me auxiliou de forma bastante construtiva, como também me ajudou a descobrir muitos enigmas de seu percurso formativo como arte/educadora.

O terceiro encontro deu-se em 2015. Conheci Letícia de Oliveira Mello ${ }^{25}$ no início do ano: éramos recém-chegadas ao Colégio São Domingos. Construímos afinidades, mas nossa relação se intensificou apenas em 2016. Naquele ano, fomos professoras de algumas crianças em comum. Letícia era professora do Grupo 5 do ensino regular (que no colégio chamamos de Agrupamento Azul) e eu começava meu trabalho como professora da USINA (Unidade Semi-Integral de Intensificação em Arte). Durante o período da manhã, eu ficava com as crianças realizando experimentações e proposições em arte e, à tarde, elas iam para escola no período regular. A escola recebera novos estudantes; no entanto, naquele ano, um novo aluno surgiu para revolucionar e transformar para sempre nossos caminhos. Ele tinha 5 anos e nos chegou com uma experiência escolar muito negativa. Apesar da pouca idade, tinha passado por duas escolas de Educação Infantil com o perfil duvidoso e fora convidado a se retirar de ambas. Carlos ${ }^{26}$ já havia passado por três instituições. A primeira foi um orfanato no qual viveu

25. Letícia tem 30 anos, formou-se em Pedagogia pela FEUSP no ano de 2015. É pós-graduada em Arte/Educação Lato Sensu (2017/2018) pela A Casa Tombada com o seguinte título de trabalho: "Das vilas que me Habitam", do qual fui membra da banca no início de 2019. Há 5 anos, Letícia é professora da Educação Infantil e atualmente trabalha com o Grupo 5 no Colégio São Domingos.

26. Por se tratar de uma criança, escolho um nome fictício para relatar essa experiência: chamo, então, de Carlos. 
seus primeiros anos de vida até ser adotado por uma família muito afetiva. As marcas de tantas rejeições compunham sua subjetividade; era uma criança que se expressava pelo corpo e, muitas vezes, de forma agressiva e violenta, tanto com ele mesmo quanto com os outros colegas. Mas como ser diferente em meio a tantas agressões em que a vida o tinha colocado ainda tão pequeno? Letícia e eu formamos uma parceria enorme, víamos em Carlos muitas coisas além do que ele podia mostrar: para nós, não era apenas uma criança agressiva e com problemas: era mais que isso, melhor que isso, um transgressor, na potência total dessa expressão. Nos colocava em cheque o tempo todo, nos mostrava que a vida não era feita de caixinhas em que se revelasse o certo e o errado. Mais do que isso, Carlos nos mostrou as brechas em que a humanidade se faz, os vazios deixados. Ele nasceu na marginalidade; sua mãe biológica, mulher negra em situação de rua, veio a falecer logo que o pariu. Ele, por sua vez, precisou ficar um tempo internado para poder sobreviver, nasceu dependente químico de crack e, ao se restabelecer, não encontrou um lar, mas sim uma instituição que o abrigou até ser adotado. Essas marcas foram sua constituição primeira, seu corpo tão pequeno contava essa história de abandono, de sofrimento e vergonha humana. Não podíamos deixar de nos sensibilizar com elas: professoras ativas e em comunhão com nossos estudantes, passamos aquele ano jogadas em um abismo das incertezas. Queríamos construir com ele outros modos de existir, trazer sensibilidades, acolher suas dores e mostrar outros possíveis. Considero que, por mais tortuoso que possa ter sido, tivemos muito êxito. Carlos já não é mais o mesmo, fomos capazes de construir afetos entre nós e ele. A cada superação de seus desafios, a cada produção e desenvolvimento de relações sensíveis produzidas por ele, vibrávamos juntas. Choramos, sofremos e gozamos em comunhão do que acreditamos como educação. Vias e cruzamentos, caminhos sinuosos de transformações. Corpo e mente que doem e sentem a força que a educação tem na (trans)formação humana, força de potência, de superação, de sensibilidade e de amor. Essa experiência nos marcou profundamente, para sempre, e a cada ano nos mostramos abertas a qualquer desafio que possa aparecer. A educação que acredito e procuro realizar se faz pelo respeito às singularidades, às subjetividades, ao respeito pelas histórias e experiências que carregamos. Pelo desafio da escuta, do sair do controle, de aprender com o outro, de se fazer com e pelo outro. Compreendo que meu percurso formativo nas práticas educativas e artísticas me auxiliaram a desenvolver este devir. Acho que naquele momento aprendi a ser uma outra professora: eu também não sou mais a mesma e me constrú junto com Letícia. Nosso vínculo pela educação é enorme, nossas buscas muito similares. Ela, como eu, deseja transformações, deseja buscar nas expressões artísticas uma forma de constituição e expressão humanas.
A quarta voz é de Bianca Bressan ${ }^{27}$. A conheci recentemente quando, em 2018, cursamos uma disciplina sobre o pensamento de Paulo de Freire na contemporaneidade, na Faculdade de Educação da USP. Por alguma razão, criamos afinidades, sentávamos perto, conversávamos sobre nossas práticas, pesquisas e fizemos um seminário juntas com outros colegas. Trazer a voz de Bianca para minha escrita foi muito valioso: além de atuante da escola pública, também desenvolve sua pesquisa refletindo sobre sua prática e busca compreender relações entre os campos da Arte e Educação. Bianca tem uma história que merece ser narrada. Professora convicta de duas escolas públicas, esse sempre foi seu desejo. Descobri muitos outros aspectos de seus percursos formadores e mais adiante os narrarei aqui.

Mergulhar e conhecer a fundo os aspectos formativos e os trajetos percorridos pelas colegas suscitaram-me memórias e me ajudou a pensar na temporalidade dos acontecimentos vividos. As memórias infantis que podem, talvez, em certos casos, justificar a sensibilidade pelas linguagens artísticas. As memórias escolares das vivências na universidade, o encontro com as crianças e a busca permanente em problematizar e (trans)formar suas práticas educativas deram-se em uma perspectiva da oralidade, da fala, ou seja, da narrativa oral, ou como nomeia Ecléa Bosi "memória oral":

A memória oral, longe de unilateralidade para a qual tendem certas instituições, faz intervir pontos de vista contraditórios, pelo menos distintos entre eles, e aí se encontra a sua maior riqueza. Ela não pode thos entre eles, e al se encontra a sua maior riqueza. Ela não pode cham una teoria da históra nam pretende tal fato: ela ilustra o que chamados hoje a História das Mentalidades, a Historia das Sensibilidades. $(2013$, p. 15$)$

Tais memórias foram compondo um certo mosaico, um desenho, um mapa que, ora trazia uma certa linearidade com o tempo, ora me deslocava para outro lugar. Assim começa a nascer uma história sensível de caminhos e andanças que foram percorridos pelas colegas. Nesse momento, construí um roteiro semiestruturado que abordava as seguintes questões: 1- Que experiências marcantes a levaram escolher o caminho da pedagogia em sua formação inicial? 2- Como foi seu percurso formativo na graduação? Fale sobre suas experiências na universidade, as aulas mais marcantes, as vivências nos espaços estudantis e seu trânsito pela universidade. 3- Como encontrou caminhos para desenvolver aprendizagens em sala de aula no campo da arte, ampliando seus conhecimentos e possibilidades de trabalhar este campo em suas práticas educativas? 4- De que maneira relaciona o

27. Bianca tem 29 anos, formou-se em Pedagogia pela FEUSP no ano 2010. Trabalha como professora da Educação Infantil no munićpio de São Bernardo do Campo há 11 ano e no município de Santo André há 5 anos. É mestranda pela Faculdade de Educação, desde 2017 
campo da Arte à sala de aula? Você estabelece diálogo desse campo com outros saberes? Dê um exemplo de uma situação em que as linguagens artísticas se fizeram presentes em seus percursos formativos. Apesar de apresentar essa estrutura, suas narrativas iam de lampejos da universidade para a infância, traziam lapsos, abriam fendas nas memórias que há tempos não eram solicitadas. Trouxeram suspiros e suspensões de uma experiência de vida marcada pelo desejo e descobertas.

Com Carolina, Priscila e Letícia o encontro aconteceu em minha casa e de forma separada: acolhidas em um espaço bastante particular, realizamos as conversas por pouco mais de uma hora. Bianca, por viver em São Bernardo do Campo, sugeriu um encontro mais próximo de sua residência. Fui de trem até Santo André e lá nos encontramos em uma lanchonete por aproximadamente uma hora e meia. Realizei as entrevistas no período de novembro a dezembro de 2018. Capturei os relatos em meu gravador, ouvi e reouvi repetidas vezes até que pudesse desenhar um percurso singular de cada uma. Além das questões estruturantes, pedi para que as colegas escolhessem uma imagem ou uma fotografia que refletisse aspectos, pesquisas e caminhos de suas práticas naquele momento.

Me lancei, assim, na tentativa de capturar lugares que me ajudassem a refletir sobre os aspectos constitutivos de suas vidas. Desenhando uma história, narrando a partir do que capturei de substancial, marcada pela sensibilidade de uma escuta que não pensa em encaixotar e marcar fronteiras no que foi exposto mas, sim, desvelar caminhos cheios de desvios, trajetos, passagens com curvas que marcam andanças pela arte e pela educação. Por compreender que os aspectos formativos são constituídos por caminhos, viagens a lugares desconhecidos e, muitas vezes, ao imprevisível, nos observo como mulheres viajantes, caminhantes e navegantes de situações que nos revelam aprendizagens, conhecimentos e devires que nos fazem arriscar e conhecer outras formas de viver - novas formas de olhar e construir um outro eu. Como navegantes, considero que nos lançamos ao mar, vivenciamos a dúvida. Não sabíamos exatamente aonde chegar; mas, ainda assim, escolhemos e desejamos navegar, como salienta Sumaya Mattar (2002, p. 42):

Mas nem todos os homens desejam navegar. Alguns ficam parados no tempo e no espaço, preferindo o recolhimento em um terreno demartempo e no espaço, pre lino o recol cado a conhecer outros lugares, pessoas, linguas e paisagens. Outros tantos são como náufragos - expressão utilizada por Marina (1997) para designar os seres humanos, já que precisam construir um corpo de valores éticos que os permita, utilizando sua inteligência criadora, forjar projetos que os mantenham sempre à superfície, ou seja, com controle sobre a própria vida - que, lançados em meio ao oceano a esmo, precisam se apoiar em um objetivo qualquer para não submergirem definitivamente.

Justamente lançadas a esmo, às incertezas, é que começo a dialogar com o material das entrevistas. As colegas são viajantes de um tempo histórico, náufragas, inquietas e desejantes de algo; esse desejo nem sempre se ancorou em certezas, mas na necessidade de viver a novidade e de colocar a vida em movimento. Assim escolheram um objetivo: a jornada pela faculdade de educação.

Trabalhar com entrevistas é também navegar por incertezas. Apesar de conhecer o trabalho e as pesquisas das colegas, nada me garantia que encontraria a rota desejada. Entre tantos deslocamentos, outras possibilidades foram lançadas, outras perspectivas e outras subjetividades. Não se trata aqui de apontar o que foi assertivo, não queremos isso. Objetivamos, sim, mostrar o quanto os deslocamentos são constitutivos na vida de mulheres e homens que se lançam ao mar, ao desconhecido.

Durante as entrevistas, compreendi que algo muito valioso estava sendo exposto. Elas, então, falavam o que tinham capturado de seus desejos e andanças e eu, duplamente, os capturava e transpunha para a construção de conhecimento. Encontrei matéria bruta, singular, e tentei desenhar uma cartografia das memórias procurando encontrar um desenho do que Sumaya Mattar (2017, p. 3280) nos diz sobre cartografar:

A cartografia favorece a representação multifacetada - simbólica ou real - de tais fluxos, ou seja, o traçado do caminho que se deseja percorrer e a visualização do já percorrido, além das necessidades e inevitáveis possibilidades de mudança de rota, e isso pode se dar com diferentes linguagens juntas, ocupando o mesmo suporte e/ou plano. Também possibilita a representação de um tema, objetivo ou fenômeno, a organização e o encadeamento de conceitos, a comunicação de pensamento e o desenvolvimento da imaginação, já que seu alcance não se limita à realidade nua e crua.

Embora eu pretenda narrar as experiências de vida das quatro pedagogas, há de fato uma apresentação multifacetada - simbólica ou real, pois muito do que foi exposto diz respeito a expressões de relações, por meio das quais as parceiras foram se recriando e se desenvolvendo a partir de símbolos que emergiam em seu cotidiano real. Outro aspecto já mencionado forma as mudanças de rota: algo se apresentava e desviava para se pensar a arte e a educação como atividades, como narram minhas parceiras indissociáveis de suas vidas.

Proponho construir uma reflexão como narradora-cartógrafa das viagens apresentadas nas entrevistas. Desenvolvi uma teia onde investigue o que florescia e emergia nas narrativas: os gestos trouxeram afetos, pois me deparei com exposições, identifiquei-me com cada história, mesmo que expressando singularidades bem marcantes. Lanço-me, então, a transformar esse material em cenário, em fios e narrativas pelos campos da Arte e da Educação. Não sigo sozinha nesta escrita: Bianca, Carolina, Letícia e Priscila caminham comigo. Afirmo que não apenas pelas entrevistas, mas também pelo empréstimo afetivo de suas memórias, por toda viagem, comum e sin- 
Começo a desbravar essa tarefa trazendo cada uma separadamente. Primeiramente, transcrevendo o que há de singular em cada percurso, para depois cruzar as linhas e andanças. Procuro nomear o percurso de cada uma, trazendo suas imagens e construções. Cada subtítulo deste capítulo aproveita uma frase advinda das falas de cada entrevistada, capturo nelas um gesto que expressa de forma ampliada o que está sendo exposto. Escolho iniciar na ordem cronológica dos encontros, para depois esbarrar no tempo e desconstruir suas fronteiras.
Marquei um encontro com Carolina em minha casa após o trabalho. Ela chegou em casa por volta das 19h, tomamos um chá, conversamos um pouco e começamos a entrevista. Embora a conhecesse desde 2009, muita coisa foi revelada nesse processo todo. Como havia escrito no roteiro, perguntei primeiramente: que experiências marcantes a levaram escolher o curso de Pedagogia em sua formação inicial? De modo geral, o desenho das demais questões foram se fazendo a partir da resposta a essa primeira. Para ela, não precisei perguntar a respeito das experiências vivenciadas na Universidade, pois, ao responder esta questão, aquilo que dizia respeito à vivência estudantil foi sendo narrado naturalmente. Descubro que o desejo pela pedagogia sempre esteve nela. Desde criança, Carolina parecia saber o que gostaria de ser. Há, no entanto, um fato bem importante: filha de pedagoga, teve em casa uma forte referência. Como ela mesma diz:

Minha mãe é pedagoga, ela foi professora de educação infantil minha infância toda. Agora não é mais. Mas é uma referência muito forte; desde criança, perguntavam: "o que você quer ser quando crescer?" E eu respondia: "eu quero ser professora". As pessoas me perguntam se eu tenho alguma professora que me fez querer ser professora e eu não sei responder. Na verdade, eu sempre quis ser professora. Na hora de prestar vestibular dá aquela dúvida, acabei prestando um monte de coisas, inclusive prestei Relações Internacionais. Tinha uma fantasia de trabalhar na ONU e salvar o mundo. Isso, conforme fui crescendo e amadurecendo, a coisa ganhou outra dimensão, mas acho que minhas buscas sempre tiveram o desejo de ter um potencial transformador. Transformar alguma realidade que precisasse ser transformada. Parece alguma coisa ingênua, idealista, mas passou por aí minha escolha. Por isso, desde que entrei na faculdade, trabalhar na escola pública sempre foi meu foco. Acho que de alguma forma sempre senti uma vocação, que também não sei explicar muito de onde vem, mas sempre foi um desejo (...). Quando fui prestar vestibular, acabei prestando Jornalismo e Ciências Sociais, essas opções foram mais pensando em morar fora da cidade de São Paulo (...). No final, acabei passando só em Pedagogia na Faculdade Educação da USP. E achei: ufa, pronto.

Escolher atuar no campo da educação passou por afetos de natureza distinta. Além da referência familiar, houve também o desejo por transformações sociais. Desejo esse que passa pelo afeto humano, pela alteridade, pelo reconhecimento do outro, dos modos distintos de existir e por abrir-se em se transformar com outro. Ela passa a mexer nas estruturas tão con- 
fortáveis da vida e sai à procura de outros possíveis. Sair da sua condição já consolidada foi fundamental: buscando construir utopias, encontra na universidade a possibilidade de sair do seu lugar comum, encontra o diferente e as inúmeras possibilidades que a vida lhe apresenta. Saiu de si, saiu à deriva, navegou por águas desconhecidas e começou a se (trans)formar e a se constituir de outros modos, conhecendo outras subjetividades e novas camadas na consolidação do ser professora.

O mais importante que aconteceu na USP foi ter conseguido romper a bolha. Tudo bem que a USP também é uma bolha, mas eu cresci em uma escola, passei 15 anos da minha vida com as mesmas pessoas, fazendo as mesmas coisas e com as mesmas referências. O Colégio Vera ${ }^{28}$ tem um caráter crítico e tudo mais, é voltado para humanas e para as artes, reconheço que foi fundamental na minha formação. Mas ainda assim é uma bolha muito específica e muito homogênea. Quando entrei na USP, percebi que fui capaz de entrar em contato com um ambiente muito mais heterogêneo, ainda mais na pedagogia. Porque o curso de Pedagogia tem mais essa característica, acho que até mais que outros cursos da USP, de todas as unidades, não é tão elitista. Então, me relacionar com pessoas tão diferentes, com trajetórias diferentes e me aproximar delas, enfim, conhecê-las, ouvi-las, tudo isso foi muito transformador para mim. E quando você vem de um lugar muito igualzinho, você acaba se encaixando, essa coisa é um pouco sufo-

cante. Eu me encaixava ali, essa coisa de ser igual às minhas amigas e seguir um padrão. Daí quando me deparei com esse ambiente, pensei: eu posso ser outra coisa, posso ser um mundo e isso foi muito especial para mim.

\subsubsection{Um entender do lugar da pedagoga e seu papel} de transformação

Carolina, ao narrar sua experiência, narra com o corpo e os olhos pulsando. Algo muito importante aconteceu em sua existência nesses anos de universidade. Algo modificou, tombou, tremeu e deixou marcas que a auxiliaram a se constituir enquanto uma pessoa mais aberta ao imprevisível, à aventura ao desconhecido. Ao falar sobre as aulas marcantes da Faculdade de Educação, faz da memória sua linha de edição, captura existência. Possui Educação Infantil, Ensino Fundamental I e II e Ensino Médio. o que tem de mais relevante, o que foi fundamental para expandir seu conhecimento crítico. Passa a viver intensamente a vida de estudante, atuando em assembleias, centros acadêmicos e experiencia a vivência na esfera política universitária.

Acho que essa foi a primeira coisa que eu lembro da FEUSP, o quanto aprendi com as pessoas que têm trajetórias diferentes da minha. E essas pessoas eu não conheci exatamente na sala de aula, mas muito de minha relação com o Centro Acadêmico, esse ambiente foi fundamental. Ver pessoas olharem para o mundo de outro jeito foi muito bom. Foi o movimento estudantil, cara, não fazia ideia o que era uma assembleia, o que era o posicionamento político efetivo, isso tudo encontrei na USP. Virar assembleia, noites e noites, no começo rola um deslumbre, me mobilizava em muitas causas. Passa um tempo você se pergunta: meu deus, tanto trabalho não deu em nada? Mas foi muito importante esse contato com a política, que apesar da minha família ter todo envolvimento, isso não era meu, antes era meio alienada. Para além disso, acho que, no primeiro ano, as matérias de sociologia, filosofia e psicologia foram também muito importantes (...). Nunca soube aproveitar isso na escola, porque quando converso com os meus amigos do Vera, eles sempre falam: nossa, aprendi muito. (...) O Bourdieu ${ }^{29}$, por exemplo, ali, naquele momento, foi muito esclarecedor para minha vida. Sabe, me colocou óculos para olhar a sociedade e fazer uma leitura mais complexa, mais refinada, e foi muito bom. A professora era Kimi, foi muito importante. O Sérgio também foi, ele falava sobre Walter Benjamin. ${ }^{30}$

Enfim, esses conhecimentos foram bem transformadores. Apesar de não ser uma aluna muito aplicada, sinto falta disso. Se eu tivesse entrado agora na universidade, acho que saberia aproveitar melhor, porque era tudo. Estava em contato com toda essa novidade e essas transformações. Estava motivada ali por muitas coisas que não só a academia. Eu vivi muitos processos formativos, fico muito feliz de ter ido pra USP.

29. Pierre Félix Bourdieu (1930-2002) foi um sociólogo francês que influenciou de forma profunda a sociologia da educação.

30. Walter Benjamin (1892-1940) nasceu na Alemanha. Era filósofo, professor universitário e ensaísta. Seus escritos abordam diversos temas, inclusive as infâncias e a juventude como grandes potências de subversão da história. Foi fortemente influenciado pelos escritos de marxistas e tinha uma relação profunda com o teatrólogo Bertold Brecht Suicidou-se na Espanha, ao perceber-se cercado pelos nazistas. Sua obra é para mim uma grande referência. 
A universidade também trouxe um entender do lugar da pedagoga e seu papel de transformação. Porque a gente chega aqui e quer abraçar o mundo e de repente você vê que existe um mecanismo social, tudo muito complexo, que não é só a educação que vai salvar o mundo. É uma ferramenta importante, fundamental, mas que também está contaminada de todas as problemáticas da sociedade. Me colocou bastante pé no chão.

Pensando sobre as transformações pessoais e sociais capturadas por Carolina na universidade, o devir professora e o vir a ser outra coisa também passam a ocupar suas andanças formativas. Acho bastante singular ela narrar as inúmeras possibilidades de constituição que a universidade the trouxe. Não foram apenas experiências advindas da sala de aula mas, também, dos espaços estudantis, das relações que estabeleceu e das questões sociais que permeiam nossa existência. São saberes complementares ao meu modo de ver. Há quem passe por essa experiência focada apenas no curso, mas há, no entanto, quem passe a viver a universidade como um todo, aberta a todas as possibilidades que ela pode oferecer como processos formadores. Assim como também, de certa forma, vamos amadurecendo com o processo, transformando nossas certezas em incertezas e mudando a rota inicial. Isso acontece quando a vida deixa transbordar, quando somos capazes de refletir de forma consciente o processo que vivenciamos, a partir do qual experimentamos outros modos de ser e de pensar.

\subsection{A relação com a arte vem muito}

da minha infância

Neste ponto, o fio narrativo da experiência universitária passa a encontrar outro ponto, outro fio e outro momento. A universidade trouxe essas camadas constitutivas à Carolina. Mas houve uma experiência anterior, algo que também marcou e que a constitui fundamentalmente até os dias de hoje. Essa marca, como as deixadas pela universidade, nunca mais sairá de seu corpo. Na entrevista, contudo, Carolina ganhou outra edição, outros modos de pensar, solicitou memórias mais antigas, iniciais e infantis. Ao indagá-la sobre as experiências em arte, descubro que tais experiências não eram recentes como as da universidade e, sim, algo que aconteceu ainda quando criança e percorre sua vida sempre.

A relação com a arte vem muito da minha infância, da minha adolescência, foi quando eu tive mais contato com Arte no sentido de fazer. Sempre fui uma criança que tive muita liberdade para desenhar, pintar e dançar. Na escola que eu estudei isso sempre foi muito valorizado. Tive muita aula de arte, ótimas professoras que sempre trouxeram muitas experiências, referências diferentes e diferentes técnicas.

Experiências nas diversas linguagens: artes plásticas, dança, música e teatro. Vivi muito isso na escola, acho que foi fundamental. Para além da escola, sempre fiz coisas extras, fiz aula de desenho e de dança. Na minha família isso é muito presente: meu pai é artista e meus tios também. Mesmo meus tios que não seguiram carreira artística também são envolvidos. Isso sempre foi muito presente, sempre me senti muito contemplada. Sempre me senti muito realizada. Sabe aquele momento de realização? Era quando eu desenhava, quando eu pintava e dançava. Acho que só fui conseguir fazer essa leitura depois de mais velha, porque quando você é criança você só vive. Na Universidade, quando você começa a se pensar professora. E logo que entrei na universidade comecei a ser professora, no primeiro ano de faculdade já entrei na escola, na educação infantil -, veio naquele momento, quase que intuitivamente, um desejo de proporcionar isso para as crianças.

Essa experiência particular corporificada em Carolina me faz refletir sobre um aspecto fundamental para se pensar a importância de se realizar processos artísticos na escola. Não apenas por essa narrativa, mas aqui está presente um relato substancial de como as práticas e a relação com as linguagens artísticas são fundamentais para a constituição humana. Como professora, também consigo observar com clareza o que Carolina denomina como momento de contemplação, apesar de haver contingências e contradições: atuar com crianças nem sempre se faz possível em uma linha reta. Ser professora também é vivenciar momentos de dificuldades, dúvidas, aulas que não chegam ao que planejamos. Mas apesar disso, é muito recorrente observar nas crianças um processo muito particular quando estão imersas nas experiências em arte. São atividades quase inerentes na constituição da infância. O desenho, por exemplo, é uma forte expressão. Ele, no entanto, não aparece apenas na aula de arte. Na verdade, ele é sempre recorrente: em qualquer momento de pausa, as crianças estão desenhando. Quando era professora do ensino regular, me chamava muito a atenção perceber que, a qualquer momento de dispersão ou tédio advindo de alguma aula, como por exemplo, um estudo sobre questões textuais, lá estavam as crianças desenhando, ainda que fosse na margem do caderno, ou mesmo do livro. Isso sempre me instigou a refletir por outro lado, como desenvolvi no primeiro capítulo: as crianças têm uma característica arteira, artística. Se expressam e se manifestam pelo desejo de criação o tempo todo. Dançam ao pintar, teatralizam ao brincar. Dependendo da condução, noto que, nas aulas de arte, elas constroem conhecimento, aprendizagens, dúvidas, questionamentos, se fortalecem, conhecem a si mesmas; como também trazem contemplação, prazer, suspensões, são aulas que atuam em um tempo outro.

Além do mais, ao somar as práticas artísticas aos demais conteúdos trabalhados, os saberes que constituem as práticas educativas que envol- 
vem a Educação Infantil e Ensino Fundamental I potencializam os percursos formativos das crianças. À medida que aprendem criando seus saberes, levantando questionamentos, expandindo a capacidade de olhar para o objeto de estudo de vários ângulos e rompendo fronteiras, as crianças, nesses momentos, criam marcas profundas em suas experiências escolares, a si e ao que apreendem.

Essa materialização se faz muito presente no relato da colega; para ela, é natural pensar a infância e sua relação com a arte de maneira orgânica. Por mais que aqui seja possível observar uma característica bastante particular de uma vida repleta de experiências no campo da arte, uma vez que ela é oriunda de uma família de artistas, muitas dessas experiências aconteceram na escola, ou em aulas extraescolares. Esses aspectos a formaram, a transformaram de modo que essas vivências nunca saíram de seu corpo e de sua memória, e voltam com mais intensidade à medida que se vê professora. Pois lhe é sabido o quanto são potentes essas práticas desenvolvidas na infância.

\subsubsection{Vê-las descobrindo e criando é uma sensação} de muito prazer

Carolina passa a refletir sobre questões de sua experiência escolar: a arte foi fundamental em sua constituição. Nesse momento, a fala aciona a memória do corpo, a memória do que é fundamental.

Isso sempre me trouxe muito prazer, é uma leitura que eu fiz inclusive recentemente. Eu gosto tanto de oferecer para as crianças fazerem coisas com materiais, tintas, porque eu lembro muito do prazer que isso me dava quando eu era criança, esse prazer que me trazia e me traz ótimas lembranças. Então me dá muito prazer com as crianças. Vê-las explorando, vê-las descobrindo e criando é uma sensação de muito prazer, sinto falta disso na minha vida e de certa forma me realiza muito fazer isso com elas.

Há algo da experiência docente revelada aqui que é bastante fundamental. Quando a experiência docente é realizada em comunhão dos saberes, como nos ensinou Paulo Freire, é quase que natural olhar para as crianças olhando para nós mesmos. Proporcionar situações de aprendizagem que sejam prazerosas, fazer do ensino também um processo no qual esteja inserido o desejo pela curiosidade, pela experimentação. Proporcionar ao outro o que proporcionaríamos para nós, o que nos faz bem, o que nos faz ter vontade de aprender, de pensar e refletir sobre os inúmeros aspectos que os saberes nos proporcionam. Essa troca faz parte de uma compreensão bastante sensível a respeito do devir professora, ou seja, do ser professora. Olhar com lentes de aumento a sala de aula, pensar nas práticas de ensino que possam acontecer a partir de suspensões e processos de experiência. Ter vivenciado a experiência com diversas linguagens artísticas foi tão importante na constituição subjetiva de Carolina que ela é capaz de processar esse conhecimento e garantir aos seus alunos essa possibilidade. Ela, então, revela os campos de forças, potências, desafios e dificuldades que a formaram.

Acho que as artes plásticas e a dança, mesmo estando parada e, não sei porque são as linguagens mais fortes, na verdade o corpo. Já o teatro na adolescência, acabei dando uma travada, pois não me dediquei, mas enquanto criança amava o palco. Todo domingo de família, pegava minha prima e a gente criava uma peça fazia figurino e tudo. Acho que a criação é um negócio super potente. Dos 5 aos 15 anos, Acu fiz que a criçá un ño . tas-feiras, durante 10 anos da minha vida, com a mesma professora. É se perguntarem de uma professora que me marcou, foi ela. E não fo na escola. Era um lugar de plenitude total (...). Esse espaço me deixava tão viva, tão inteira... Lá a criatividade estava aflorada e realizada. Fo um espaço extremamente constitutivo. Só fui me dar conta disso quando fui fazer a aula com o professor Marcos Neira, de cultura corporal que me dei conta do quanto isso foi constitutivo. Essa vivência que eu tive na infância foi tão formativa, da relação com meu corpo, de como eu me coloco nas situações do mundo, da vida e como isso foi fundamental. Durante essa disciplina, resolvi escrever uma carta para minha antiga professora.

Cursar pedagogia, transformar-se em professora da Educação Infanti e Ensino Fundamental I, relacionar-se com a infância, estudar e pesquisar as manifestações da cultura infantil são fontes de saberes bastante singulares. Há um elemento importante dessa aprendizagem que é a solicitação de memórias. A educação como prática de uma relação crítica e compartilhada com os estudantes nos faz olhar no outro o nós. Carolina passa a ter consciência de seus processos de aprendizagem na infância, da relação fundamental que o corpo estabelece para a constituição subjetiva, quando é provocada a se pensar professora. Compreende que ter vivenciado experiências em arte na infância, a leva perceber o quanto esse conhecimento é vital para as práticas educativas. Educa, portanto, a si mesma a partir do que vivenciou, passa a se olhar de forma crítica e consciente. E encontra um pensamento bastante relevante para se pensar processos de ensino para crianças.

A importância de possibilitar experiências no campo das artes, campo aberto de múltiplas possibilidades aos estudantes, dá-se pelo que ficou marcado em sua memória e em seu corpo. Pensar o corpo como elemento de expressão, conhecimento, possibilidade de aprendizagem, inseparáve da mente, é algo que tem percorrido muitos debates e reflexões no campo pedagógico. Essa questão se faz presente porque nós mesmos, professoras e professores, quando passamos a refletir nosso corpo em sala de aula, 
notamos uma barreira bastante marcada. Vivemos processos de formação onde o corpo não é solicitado a pensar e se expressar, passamos parte de nossa formação acadêmica sentadas em cadeiras, pensando, discutindo e refletindo muitas questões relevantes. Vivenciando poucas questões no campo da experiência. Como, então, sermos capazes de reconhecer a importância do corpo de nossas alunas e alunos se o nosso está esquecido?

Carolina apresentou uma teia de potências que o campo da arte pode realizar na constituição de sujeitos que desejam atuar no espaço escolar. Relacionar-se com a infância, momento tão pulsante de vida, que em muitas situações se expressam pelo corpo - corpo esse que fala, brinca e cria possibilidades - é estar aberto às pistas de como se constitui o conhecimento.

Ela, então, lê uma carta que escreveu à sua professora de arte que tanto marcou seus percursos na infância e na adolescência. Vale ressaltar que, no início da conversa, ela não sabia se havia uma professora marcante em sua trajetória; no entanto, ao narrar suas experiências de vida, algo suspende na memória: lembra, então, de algo que estava esquecido, algo de extrema importância para si. Aqui fica consolidada a importância do exercício de narrar nossas memórias. Essa é uma abordagem poderosa para auxiliar-nos a refletir nossos aspectos formadores, o que nos criou e nos (trans)formou. É um instrumento importante para os tempos atuais, tempos das efemeridades, do esquecimento. Na contramão do que está posto, tais narrativas fortalecem nossa história, sobre o que vivemos e que nos impulsiona a seguirmos firmes ao que nos propomos a ser.

$\mathrm{Cy}$,

Nesses últimos tempos, tenho pensado muito em você. Estou com 22 anos cursando o $4^{\circ}$ ano de pedagogia na USP e há três anos trabalho como professora na escola Espaço Brincar.

Ultimamente, a formação do corpo das crianças tem sido um tema que tem me interessado muito. Ando estudando um pouco, observando e pensando bastante sobre o assunto.

Nesse movimento, passei a refletir sobre a minha trajetória e minha relação com meu corpo. Me vieram à tona todos os anos que frequente seu espaço. Anos tão importantes para mim. Me mantiveram sempre conectada. Mente, corpo e alma. Sensações, movimentos, emoções, criações. Música, cor, histórias, acontecidos. Sala, palco, jardim. Bolas, panos, bambus, bambolês. Amigas. Professora.

Lá eu sempre me senti presente, viva, atuante. Encontrei o melhor espaço para expressar e dar forma e movimento a toda aquela energia criativa que em mim nunca foi pouca.

Hoje percebo como tenho uma consciência corporal afinadíssima. Como tenho prazer em me movimentar da forma como faço. Como vivo meu corpo. Envolvida, atuante.

Devo muito do que sou a você, Cy. E queria dizer que sou eterna- mente grata. Carrego comigo toda essa experiência. Na memória, no corpo e no coração.

Gostaria muito de te visitar um dia desses assistir a uma aula, bater um papo...

Será que conseguimos marcar?

Um beijo enorme,

Carol.

Depois de compreender quais tipos de experiência em arte Carolina vivenciou em sua constituição, vamos refletir sobre os modos como essa experiência marca suas práticas de ensino, suas questões, dificuldades e dúvidas na atuação com as crianças.

\subsubsection{Quando estou com as crianças, a própria energia} delas me contamina

(...) Acho que isso revela bastante o porquê carrego isso na minha prática. Está em mim, querendo ou não, quando estou com as crianças, a própria energia delas me contamina e me lembro muito disso. É curioso porque muitas das minhas colegas têm dificuldade com atividades de arte. Nós temos em nossa linha do tempo (rotina), um horário dedicado à arte. ${ }^{31}$ Por mim, teríamos todos os dias. Eu planejo, é claro, mas também em vários momentos vêm na hora. Vejo o material disponível, vamos fazer isso e aquilo, o negócio flui. Nós somos responsáveis pelas aulas de arte, por tudo, aliás isso é uma questão. Estamos lendo o material da prefeitura, são documentos bem atualizados, bem bacanas, fala muito de garantir diversas linguagens, no campo artístico, cultural, das manifestações culturais, mas no fim das contas, você percebe que tem que ser especialista em arte, teatro, música, alfabetização, pensamento lógico matemático, além de dar comida. Garantir que eles não se machuquem, se machucar, cuidar, brincar e aí você fala: meu deus. Então se espera que uma pessoa dê conta de tudo isso, até foi uma discussão que eu trouxe e agora estamos pensando mecanismos de conseguir uma forma em que as crianças possam usufruir do melhor que cada professora pode dar. Para que a gente também consiga aprender com o outro. Existe muito um desejo meu e das minhas colegas de não fragmentar, mas é muito difícil. Quando fui para escola,

31. Carolina é professora da Educação Infantil na Escola Municipal Nelson Mandela, na cidade de São Paulo. 
adotei o ateliê de arte, foi um lugar em que me senti muito feliz e a partir daí fui procurar fazer aula de desenho, para retomar. Não foi nem pensando em formação para professor de arte: o movimento foi para mim, me nutrir daquilo que estava me nutrindo. (...) Na escola têm discussões bem vivas: tem eu e uma professora, que também foi do meu ano, conseguimos ter discussões sobre arte, sempre levantamos a bandeira de fazer formação nesse sentido, de colocar a arte em um lugar. Todo ano temos um tema, falamos sobre as questões, tem um registro, que são atividades direcionadas no caderno. Minha coordenadora faz uma super formação para a gente se apropriar disso tudo das ferramentas, dos projetos e exige muito nosso empenho, enfim, acompanha. Estamos levantando muito a bandeira de o porquê não se fazer isso também com as linguagens artísticas - de dar formação e também valorizar, porque fica meio ali, vamos fazer uma pintura e cantar uma música.

Minha escola é período integral, tem de manhã e tarde, esse ano a gente dividiu: uma professora fica com duas linguagens e a outra com mais duas. No meu caso, a professora da manhã ficou com música e teatro; eu com artes plásticas e dança, não à toa. Temos apenas um horário na semana para dar aula de artes plásticas e dança. Ou um semestre de artes e outro de dança, é muito pouco. Não consigo desapegar das artes plásticas para dar dança: por mais que tenha vivido uma experiência significava, tenho repertório, mas ainda assim, é mais difícil. O planejamento é mais difícil, acho que precisava de mais condução. Por isso, acabo fazendo mais artes plásticas, para mim é mais fácil, tenho mais facilidade em planejar e propor. Por isso, a dança acaba ficando de lado. Vejo que minhas colegas acabam indo onde tem mais afinidade, lógico, ninguém é especialista nas linguagens. O projeto tem três vezes por semana e a aula de arte só uma.

Há algo relevante desenvolvido nessa narrativa: professoras e professores da educação infantil precisam necessariamente dar conta de grandes demandas no seu dia a dia. São responsáveis, inclusive, pelas aulas de arte, mas como ser capaz de ensinar algo que não se aprende apenas por metodologias de ensino? Para dar uma aula consistente de linguagens artísticas é preciso vivenciá-las nos cursos de formação, aprendendo a fazer, a pensar, a ver e compreender profundamente esse campo de conhecimento. Vejam: Carolina reflete que, mesmo tendo vivenciado experiências no campo da arte, durante muito tempo de sua vida, ainda assim, não é suficiente para que se sinta tranquila em planejar uma aula de dança, por exemplo. Creio que esta problemática apresenta inúmeras facetas. Ela diz respeito tanto à formação de professores, à pouca ênfase em campos da experiência em arte, quanto às questões que dizem respeito à organização curricular das escolas.
De certa forma, embora apareçam discussões profundas a respeito da Arte na Pedagogia, há questões que estão longe de serem resolvidas. Nas discussões, tem sido debatido o quanto é comum a ideia de que Arte não é uma disciplina tão relevante quanto as demais áreas de conhecimento. O currículo imposto, muitas vezes, fragmenta o conhecimento e colocam uma espécie de hierarquia quando, ao darem mais espaços para as aulas de língua portuguesa, matemática, ciências, deixam para as aulas de arte pouco espaço. Tanto que são várias linguagens que constituem o campo da arte: artes plásticas, dança, música e teatro. É fundamental que haja um espaço para todas, com tempos e vivências comuns às demais aulas. Arte é conhecimento, fruição, expressão, forma de se relacionar com o mundo, de se conhecer, de se fazer, de expandir a potência humana, de saber olhar para o que realiza de forma crítica e criadora. Embora existam escolas e espaços que são capazes de acolher e refletir essa demanda, ainda encontramos uma dificuldade enorme em realizar aulas que envolvam arte na escola.

Há um estímulo para que possamos pensar juntos o conhecimento mas confesso que é mais difícil; para mim, é mais fácil pensar a arte pela arte. Um dia, estávamos passando por um corredor da escola e formavam sombras. Ficamos observando as sombras e a partir disso, fiz todo um projeto relacionado com arte. Fizemos contornos de sombra, pintamos, fiz uma atividade de dança, fiz toda uma dinâmica em dupla de brincadeira um com o outro. Não é uma proposta que cai do céu, cente relaciona o cotidiano, mas no projeto fico mais travada. Já tegente relaciona o cotidiano, mas no projeto fico mais travada. Ja tenho dificuldade com o projeto, percebo que há uma exigência que as crianças aprendam coisas bem específicas e eu dou uma travada. No fim rola, mas fico travada quando tem que aprender um conhecimento muito científico, por exemplo.

2.2.5. Tão triste ver criança dizendo que não sabe desenhar

(...)Agora estamos falando dos elementos da natureza a partir da horta da escola; tem uma coisa muito legal: o projeto é coletivo. Cada turma pesquisa alguma coisa e depois troca entre elas. Temos uma equipe bem bacana. Ano passado, eu relacionei muito esse tema à arte, mas foi até uma crítica. Fizemos mandala de fogo com vela, papel com limão para o desenho ficar invisível, barcos com água. Ano passado, consegui dar muita ênfase em arte. Meus alunos têm de 4 a 5 anos, é bem aflitivo perceber que quando a escrita se aproxima, eles vão parando de desenhar. Minha mãe fez um projeto de mestrado, anos atrás, que era justamente desse momento, mas acabou desistindo. $\mathrm{Na}$ rede pública é assim: eles saem da escola e já vão para o primeiro ano, 


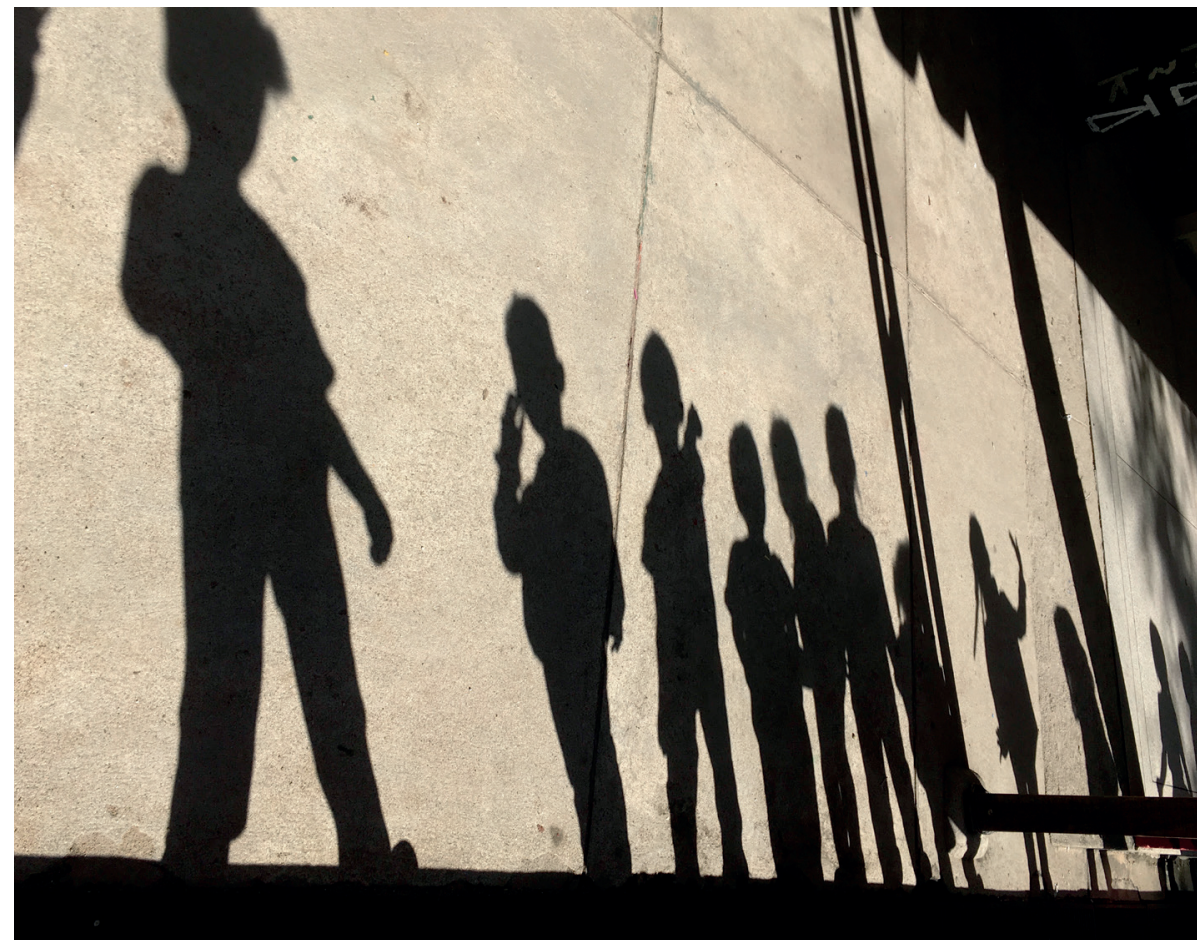

Figura 24. Fotografia das projeções de sombras das crianças tirada por Carolina Hamburguer referente ao projeto narrado, 2018. e lá é alfabetização na cara. E pensar que é uma sala com 30 alunos para uma professora só lidar com todo processo de alfabetização. Faz sentido sair mais preparadas para isso, mas, é isso: sinto que muitas vezes a gente deixa o desenho de lado para dar uma puxada na escrita. Uma coisa que percebi muito quando saí da rede particular para a rede pública. Na escola particular há muito incentivo, o ateliê era aberto todos os dias, havia especialistas em todas as linguagens, mesmo se não tinha especialistas, estávamos sempre ali. As crianças eram muito livres, não tinha essa de não saber. Lembro que fiquei com muita inveja quando voltei para a aula de desenho, as crianças são tão livres. Quando fui para a rede pública tinha muito forte: "eu não sei, não consigo". Tão triste ver criança dizendo que não sabe desenhar.

Quando uma professora não tem essa aproximação com a arte, ela acaba sempre entrando com outro propósito: "ah, vou fazer o desenho para trabalhar a coordenação motora e o traçado fino". Sempre tem um propósito pedagógico que não é a expressão. Então é difícil, vejo nelas um desejo de se aproximar disso, assim, como também tenho o desejo de pensar a matemática de outra forma. Ninguém é completo, a gente tenta no coletivo, trocar com as crianças.

Refletir e se perguntar, por exemplo, a respeito da relação das crianças com o desenho, é algo bastante pertinente. Desenho não pode ser visto apenas para ampliação da coordenação motora; é cognição, é uma linguagem fundante do universo infantil. É expressão, é a possibilidade de olharmos para uma construção de uma pesquisa a respeito do traço, por exemplo, ainda que as crianças não tenham a dimensão deste saber como pesquisa. Cabe a nós professoras e professoras a sensibilidade para refletir e olhar a maneira como que este saber está sendo construído. É uma forma de comunicação das crianças com seus saberes. Quantas narrativas imagéticas há em um desenho infantil?

Neste sentido Edith Derdyk (2010, p. 23) escreve que:

A criança, enquanto desenha, canta, dança, conta histórias, teatraliza imagina, ou até silencia. $\mathrm{O}$ ato de desenhar impulsiona outras manifestações, que aparecem juntas, numa unidade indissolúvel, possibilitando uma grande caminhada pelo quintal do imaginário.

Assim, as crianças se comunicam pelo desenho, são momentos de uma comunicação ampla e múltipla. Há representações imagéticas e o corpo também fala, pulsa, expressa, narra conhecimento de si, da relação que estabelece com o outro, com o espaço e com o meio escolar. Pensar na formação de professores dialogando com experiências no campo da arte campo aberto de possibilidades e linguagens, é expandir o conhecimento. Trata-se de constituir-nos enquanto professoras e professores abertos, crí- 
ticos, e com indagações a respeito de nossas práticas; nos pensando com o outro, a partir do outro e a nós mesmos como forma de conhecimento.

Consegui, a partir do estudo acadêmico, na universidade, fazer a leitura da minha experiência, não sei se teria feito essa leitura se não tivesse passado pela Faculdade de Educação. Isso foi muito legal do curso, não não sei se os ouctros cursos são ass olhar para minha experiência com os olhos de uma professora.

Atuar na escola, no campo pedagógico, é atuar de forma coletiva, em comunhão com os estudantes e com os demais colegas. É importante pensar a possibilidade de cada professora e professor poder dar o seu melhor, expandir suas singularidades e formações. Ensinar o que mais sabe e aprender com o outro seus desafios. No entanto, a partir do relato de $\mathrm{Ca}$ rolina, chegamos à uma reflexão mais profunda a respeito desse problema.

Aqui observada a narrativa - o relato, os trajetos, as andanças de uma professora que busca no diálogo com seus pares, seus estudantes, com a escola, a arte e os demais saberes constituídos historicamente -, podemos observar que sua experiência é bastante singular. Suas formas de desenvolver o trabalho, suas práticas educativas e de sua própria construção de si, extrai matéria bruta para construir práticas criadoras com amplitude. Está aberta ao desconhecido e faz dele potência:

Em uma das aulas de artes que eu fiz na graduação, estudei o Flávio Império $^{32}$. Era para escolher um artista e ele cabia; fui atrás de pesquisar a partir desse lugar, foi muito forte. Tem um documentário dele que eu assisto até hoje, me identifiquei muito, me inspirou muito, já era uma influência forte, depois de estudar, ele se tornou mais ainda. A percepção que eu tenho é que ele foi um grande professor, não só na universidade, mas na relação com as pessoas: como era uma pessoa capaz de virar a chavinha. Vejo meu pai falando dele, do quanto ele trazia sobre a existência, o ser humano existindo no mundo e como

32. Flávio Império (1935/1985) foi artista plástico, cenógrafo, arquiteto e professor. Brasileiro e nascido na cidade de São Paulo. Trabalhou com diversos teatrólogos como José Celso Martinez Correia e, juntos, fundaram o Teatro Oficina. Carolina é sua sobrinha neta; como ela, ele também brincava de teatro quando criança na casa da família: Comecei a brincar de teatro aos 5, 6 anos, no quintal da casa dos meus pais: cobertores presos ao varal por pregadores e muita roupa de papel de seda. Minha irmã e eu éramos atuantes e minha empregada Eunice - a nossa idealizadora e realizadora mais animada. As cadeiras da casa serviam de plateia mais as janelas dos vizinhos em frente. A coxia eram outros cobertores ou lençóis presos a outros varais. Cantava, representava e dançava. Depois das festas das escolas onde cantei, recitei, toquei piano e dancei. Extraído de: <http://www.flavioimperio.com.br/projeto/510007> Último acesso: 14 de maio de 2019. é marcante. Inclusive esse ano, pelas tantas, lá na escola e com as crianças, percebi que tem um lugar cheio de bananeiras. Entramos nessa onda das bananeiras e encontramos o mangará, o coração da bananeira. Meu tio Flávio pintou muitos mangarás. Inclusive pintei minha alfaia inspirada em uma de suas pinturas. $\mathrm{O}$ apresentei para as crianças, suas pinturas e tudo isso no espaço de artes.

Carolina finaliza nossa conversa trazendo seus afetos e a sala de aula como espaço de criação e invenção. Transita pelo campo da arte/educação de maneira convicta, ainda que permeada por dúvidas e indagações de como atuar neste campo. Aqui, o desejo pelas utopias, pela transformação, pelo reconhecimento do outro e por uma vida permeada pela arte a constituíram. Levaram-na a caminhar e navegar por águas nem sempre calmas. Mas é exatamente este aspecto de viajante que a faz e que a transforma em uma professora pulsante, crítica e criadora. 


\subsection{PRISCILA: A CULTURA DA INFÂNCIA COMO POTENNCIA DE SUA} PRÁTICA DOCENTE

Priscila veio ao meu encontro depois da aula, chegou por volta das 18h30. Enquanto eu preparava uma tapioca e esquentava a água para um chá, ela comentava como tinha sido seu dia na escola. Sempre me encanto pela forma respeitosa com a qual ela se dirige às crianças, sempre observando suas potências, seus detalhes, por mais complexos que possam ser os percursos e trajetos desenhados por elas. Ela foi a primeira professora a me provocar uma questão fundamental a respeito da forma como eu me referia às crianças. Há alguns anos, quando nos conhecemos em 2013, eu ainda tinha aquele velho hábito de chamar as crianças de meninos. Apenas repetia algo que havia aprendido na universidade e nas instituições de ensino que havia trabalhado. Referia-me às/aos estudantes como meninos. Por exemplo: "os meninos estão investigando nas aulas de história as narrativas familiares". Na época, ela era minha auxiliar de sala e um dia me chamou a atenção: Mas por que você se refere às crianças apenas como meninos? E as meninas? Começamos a conversar sobre essa questão e percebi o quanto estava me utilizando do discurso hegemônico e sexista para me referir aos meus alunos e alunas. Desde então, varri esse vocabulário, vi o quanto a nossa vida é feita pelos detalhes e sou muito agradecida pela abertura de olhos e de percepção que ela me trouxe. Por isso e tantos outros afetos.

Embora conheça Priscila há bastante tempo, nunca soube de seus trajetos, não tinha dimensão de toda sua complexidade, nem de que, desde muito tempo, a cultura da infância havia sido sua lança de partida para adentrar o campo da arte/educação. Como viajante, lançou-se ao desconhecido. Ela que não começou seu caminhar pela rota que a levaria a viver sua vida atuante como professora, das andanças primeiras, Priscila desviou-se e chegou a outro percurso.

\subsubsection{Quero ser o fogo}

Eu não decidi pela educação primeiro, nunca tinha passado pela minha cabeça. Eu queria estudar História, por admiração às professoras e aos professores que eu tive. Sempre gostei muito de História, sobretudo a Segunda Guerra Mundial, mas acabou que não rolou.

Fiz um ano de cursinho e, ao mesmo tempo, me envolvi com um grupo da minha cidade chamado "Patuscada"; era um grupo cênico e vocal. Nunca fui muito de ficar apresentando, nunca fui da linguagem falada, mas sim da escrita. Eles tinham um jornal que escrevia sobre movimento modernista e sobre a Pagu. ${ }^{33}$ Eu gosto muito dessa época, tanto que foi um dos períodos que pesquisei no meu mestrado. Escrevia, então, sobre Oswald de Andrade, Mário de Andrade e sobre as mulheres na Segunda Guerra Mundial, assuntos que sempre me interessaram. Passado um tempo, acabei me desligando do grupo e fui para a Unesp cursar Serviço Social. Foi muito pela influência, achava que ia mudar o mundo fazendo o curso. Só que eu cheguei e não era nada disso. Uma das professoras dizia que, entre as classes sociais, nós éramos a balança. Não quero ser balança entre as classes. Não: quero ser o fogo. Quero que tenha igualdade entre as classes, não quero que seja: "vamos ficar bem, os pobres aqui e os ricos ali".

Priscila, a princípio, pensou em escolher o curso de História pela relação afetiva que criou com o saber histórico, com as professoras e professores. Com temáticas que, desde antes de ingressar na universidade, a faziam refletir sobre aspectos estruturantes da sociedade. Escrevia sobre os modernistas, sobre mulheres e outros assuntos. Acabou, no entanto, na tentativa de alçar voos também percorridos pelas utopias de transformações sociais, indo para outro caminho, o curso de Serviço Social. Há aqueles que escolhem um trajeto; entretanto, ao se depararem com a atmosfera do caminho, decidem mudar de rota, pois percebem que esse caminho não levará ao lugar desejado. Assim aconteceu com ela. Ao se deparar com a intenção de ser a "balança" entre as classes sociais, passou a ficar desgostosa com o que estava sendo transmitido. Mas, uma vez mais, algo nesse caminho suspendeu seu andar, a fez mudar de vez a rota, encontrando o que procurava. Pelo desvio, achou o universo infantil, temática permanente em suas pesquisas.

Ao mesmo tempo, fui me envolvendo em núcleo de extensão da Unesp que trabalha com o Movimento dos Sem Terra, ${ }^{34}$ do qual faziam

33. quem resgatará pagu?

patrícia galvão (1910-1962)

que quase não consta das histórias literárias

das pomposas enciclopédias provincianas

ma sombra cai sobre a vida

dessa grande mulher

talvez a primeira mulher nova do brasil

da safra deste século

na linhagem de artistas revolucionárias como anita malfatti e tarsila

mas mais revolucionária (...)

Fragmentos do poema Pagu: tabu e totem/Augusto de Campos. Ver em CAMPOS,

Augusto. Pagu: Vida-Obra. São Paulo: Companhia das Letras, 2014

34. "O Movimento dos Sem Terra está organizado em 24 estados nas cinco regiões do país. No total, são cerca de 350 mil famílias que conquistaram a terra por meio da luta e 
parte estudantes de Direito, Serviço Social e História. Um dia, fui para "Ciranda" (núcleo das crianças). No começo, fiquei muito como observadora e assim encantada com elas. Porque até então, o que eu tinha de infância era o que eu tinha vivido e o que eu sempre via na minha cidade. Fui descobrindo outros tipos de infância, fiquei encantada, porque comecei a ter uma outra dimensão da infância enquanto criadora de cultura. Já estava desgostosa com as coisas do curso e resolvi prestar Pedagogia. Essas crianças me tocam. A realidade delas, a escola, as brincadeiras e as falas. Eu queria entender isso nas outras crianças. Também queria observar tantas outras infâncias. Óbvio que eu não tinha dimensão de infância como categoria estrutural, como categoria social, mas aquilo estava me levando para esse caminho da pedagogia. Larguei o curso e fui fazer Pedagogia. Fui observando a infância dos Sem Terra, a relação deles com a escola, o que me fez ir para a pedagogia.

O encontro com o universo infantil - a percepção de suas diversas possibilidades de existências, de criação de cultura e de expressão - foi o motor que impulsionou a companheira na busca de outros lugares possíveis. Percebeu na infância um enigma que pretende desvelar, pesquisar e que pôde ajudá-la a se constituir pedagoga.

\subsubsection{Um desenho me chamou muito a atenção}

(...) Logo que cheguei, fui atrás de bolsa e fui procurar trabalho na pró-aluno. Fui atrás de tudo isso e aí nesses caminhos fui conhecendo pessoas. Tinha uma menina que trabalhava comigo que era orientanda da Márcia ${ }^{35}$, minha orientadora, desde a iniciação científica até o mestrado e a Márcia é para a vida. Estava no fim do primeiro ano e a gente foi conversando. No meio do segundo ano, fui trabalhar em uma escola de bairro e as professoras eram chamadas de tia. O desenhos já eram feitos para as crianças pintarem. Fui observando aquilo. Quando você está no lugar e você é nova, você vai incorporan-

da organização dos trabalhadores rurais. Mesmo depois de assentados, essas famílias permanecem organizadas no MST, pois a conquista da terra é apenas o primeiro passo para a realização da Reforma Agrária." Extraído de: <http://www.mst.org.br/quem-somos/>. Último acesso em: 10 abr. 2019

35. Márcia Aparecida Goobi foi orientadora de Priscila no mestrado no programa de Pós-Graduação em Educação da FEUSP. É professora Doutora da Faculdade de Educação da Universidade de São Paulo. do. Observar os desenhos me deu um start para me relacionar mais a fundo com a Márcia. Então eu disse: "Márcia, eu quero estudar com você". Sabia que a Márcia estudava desenho infantil. Comecei a dar uma olhada nos desenhos das crianças e um desenho me chamou muito a atenção. Uma menina que desenhou sua professora: ela, professora do primeiro ano; só que a menina desenhou a professora como a branca e a professora é negra. Aí me perguntei: "como assim?" "O que é isso?” Então essas questões começaram a criar várias indagações em mim. Foi quando eu disse: "Márcia, quero estudar com você, quero saber de desenho, musiquinha - a cultura infantil mais uma vez." A primeira coisa que ela falou para mim foi: "primeiro, o que você tem que fazer, já que você quer estudar cultura da infância, é não colocar no diminutivo absolutamente nada. A gente não fala desenhinho, a gente não fala cadeirinha, não fala bonitinho. A gente fala isso por quê? Porque a cultura da infância é menor do que a nossa?" Comecei a pensar por que a gente coloca elas abaixo, por que o nosso é desenho, música e da criança é incompleto? Nunca está pronto e acabado?

Ao se aprofundar no curso de Pedagogia, Priscila busca compreender as manifestações, expressões e criações plásticas desenvolvidas pelas crianças. Busca observar no desenho tantas possibilidades de suas constituições. Passa a perceber a infância como criadora de cultura, potente. Percebe que a troca de saberes é o caminho para se relacionar com as crianças. Procura, então, compreender os aspectos peculiares da cultura infantil, encontra uma interlocutora que caminha ao seu lado, desde o início de suas primeiras indagações até suas reflexões. Em meio ao percurso e trajeto formador, a cultura da infância - sua fonte de apropriação e construção do pensamento pedagógico - esteve presente de modo marcante. Construir-se como pedagoga, na grande maioria dos casos, é se relacionar com o universo infantil. Essa relação pode acontecer de diferentes maneiras, seja observando suas manifestações e expressões ou pela forma como vão habitando os meios em que circulam. Nesse sentido, escreve Priscila Brito (2016, p. 64), em sua dissertação de mestrado:

Meninas e meninos integram uma categoria que para os adultos sempre é tida como o diferente, o outro, o estranho, aquilo que é desconhecido, mesmo que todo adulto um dia já tenha pertencido a este lugar. Lugar que é múltiplo, porque as infâncias relacionam-se com o contexto que estão inseridas. Além da multiplicidade e do estranhamento da infância (pelos adultos), outras características que compõem este conceito são a da permanência e da efemeridade.

Percebo que Priscila passa a construir seu trajeto como pedagoga procurando encontrar aspectos de permanência e de efemeridade. Tornando-se, dessa forma, pesquisadora das infâncias, assume essa tarefa para 
si própria. Vai buscar referências para tal pesquisa em diversas linguagens artísticas e desvela o que artistas criaram a respeito desse universo.

Márcia me disse assim: "você quer conhecer a infância? Então olha aqui: tem um fotógrafo que, desde a década de 30 , mostra as crianças no espaço da cidade de São Paulo e que por acaso fotografou os Parques Infantis". A primeira pesquisa foi a iniciação científica. Observei as crianças na cidade de São Paulo no período em que o Mário de Andrade ${ }^{36}$ era secretário do Departamento de Cultura. Então você via as crianças na biblioteca circulante, nos mesmos espaços que você via as crianças na biblioteca circulante, nos mesmos espaços que
os adultos e você via as crianças brincando. O B.J. Duarte ${ }^{77}$ tinha um os adultos e você via as crianças brincando. O B.J. Duarte ${ }^{37}$ tinha um
olhar da infância parecido com o olhar de Mário de Andrade. O Mário queria que tudo fosse fotografado para mostrar as ações do Departamento de Cultura. Para ele a infância é muito importante. A Márcia formação como pesquisadora e como professora. Além dela, vieram as professoras Patrícia Dias Prado, que também pensa a cultura da infância na Educação Infantil. Ela fala das transgressões das crianças para cia na Eduççăo Infantil. Ela fal das trangrescos para nos estágios de observação, quando se separa as crianças "pequenininhas" das crianças grandes. E elas querem estar juntas e a gente morre de medo de machucar, o que não acontece e o encontro é muito bonito. As crianças grandes acabam cuidando das pequenas, ensinando várias coisas, e as pequenas também ensinam para as grandes. Sempre gostei muito da educação Infantil. Isso tudo foi me chamando atenção e foi construindo meu olhar para a infância. Também tem a professora Maria Letícia, ela traz a sociologia da infância enquanto categoria social e categoria estrutural. A professora Flávia Schilling e o professor Eli, ambos da Sociologia também contribuem ampliando meu olhar. Por ambos da Sociologia, tambén contribuvit, Po exempla, a Flávia fala muito do Foucault, vocên entende a estrutura da sociedade, assim percebe como a gente se relaciona com as crianças. isso, você vai pensando a escola do olho que tudo vê, as crianças estão sendo vigiadas todo tempo. Espaço da escola é um espaço que cerceia. Lembro de uma frase em que ela dizia que: "a carteira é feita gente precisa cercear esse corpo?" Isso foi chamando minha atenção e construindo meu olhar. Ela também fala da mesa do professor: "ela é feita para afastá-lo dos alunos." Então você vai pensando a escola com outro olhar. Fui mergulhando nisso. me trouxe essas referências e elas foram muito importantes na minha esse mundo que a gente acaba impondo a elas. Sempre percebia isso Essa sociedade do controle, escola, vigiar e punir. A escola é feita pra pra cercear o corpo da criança, desde muito cedo; e por que é que a

Priscila, ao tecer seus fios narrativos e formadores, entende a universidade como potência para afinar e aprofundar seu olhar em relação à cultura da infância. Dessa forma, desenha seu trajeto de (trans)formação. Para ela, o encontro com a pesquisa, professoras e professores, a auxiliou a compreender melhor o campo da Sociologia e da Filosofia da Educação. Também trouxe aprendizagens e saberes advindos da Educação Infantil, situações fundamentais para seu desenvolvimento. Vai se construindo professora assim, a partir da relação com os estágios, indagando questões e construindo problemas que dizem respeito à produção das crianças. Atuar no campo da pesquisa, desde os primeiros anos de graduação, foi uma experiência singular no seu devir professora.

A fotografia pelas lentes de B. J. Duarte são sua grande fonte de alimento. A linguagem fotográfica passa a ser sua lente de aumento para compreender os aspectos históricos na formação da ideia de cultura da infância enquanto categoria estruturante da sociedade. Todas essas esferas de formação passam a auxiliar Priscila a indagar questões problematizantes a respeito do campo da Arte na Pedagogia. Desse modo, Priscila considera que a cultura são os modos diversos de se organizar em sociedade; modos de se relacionar com o mundo, com o meio onde se está inserido e com os outros seres sociais.

\subsubsection{Criança também faz arte}

E assim comecei a problematizar muitas coisas, as metodologias na Faculdade de Educação não me ajudaram, de verdade. Como, por exemplo, a metodologia do ensino em Arte. Passei a problematizar muita coisa. A professora da época falava que a Arte não estava nas ruas mas, sim, nos museus. Eu pensava: por quê? Com todo esse estudo a respeito do Mário, as fotografias e os Parques Infantis afirmavam que a criança também produz cultura, produz Arte através de brincadeiras e do corpo. Por que isso só está em museu? Por que não está na rua? Por que que a gente coloca as coisas numa caixinha? Problematizo muito essa ideia de hierarquia: só artista que está em museu é artista de verdade? Não, criança também faz Arte. Com isso, fui questionando várias coisas que aconteciam na sala de aula. Fui construindo meu percurso como educadora a partir dessas questões. A arte começa na infância e a gente vai podando muito cedo. Temos essa mania de achar que somos melhores em tudo. Resolvemos dizendo que a arte está no museu e os artistas são aqueles que só estão no museu? criadores e diretor do Departamento de Cultura do município de São Paulo a partir de 1935. Referência em: Apud "Foi respeitada a expressão da criança quando disse o que fez? - Artes nos Parques Infantis através das fotografias de Junqueira Duarte." São Paulo, FEUSP (Dissertação de Mestrado), 2016.

37. Benedito Junqueira Duarte foi um fotógrafo paulistano. O fotógrafo que revela as fotografias dos Parques Infantis(...) captura imagens que são testemunhos de um tempo histórico(...). (BRITO, p. 84, 2016)
Essa problemática levantada por Priscila é uma questão bastante relevante para se pensar o lugar da arte nas formações acadêmicas. Sim, ela 
é expressão, conhecimento, forma de narrar o mundo em que vivemos e atuamos. Não é possível pensarmos que essa expressão esteja presa apenas em museus. Ao relacionarmos a arte de forma aberta e criadora em nossas práticas educativas, somos capazes de observar o quanto as crianças são pulsantes por expressões. Elas criam possibilidades inimagináveis, apresentam uma outra maneira de organizar o mundo. Ao entrar em contato com um simples tecido, por exemplo, ele se torna capa, asas, rios e túneis para habitar outros espaços. São artistas arteiras, como tenho defendido ao longo desta escrita. Por isso, enquanto professoras em comunhão com nossos estudantes, compreendemos que essa é uma expressão de seus saberes. São expressões artísticas e elas realmente não estão apenas em museus. Quando abordamos os saberes escolares e incluímos as linguagens artísticas em nossas práticas, estamos construindo novas possibilidades de atuar frente à cultura e à sociedade. Alimentamos a construção cultural e expressiva das crianças.

Percebo que muitas discussões sobre a arte na pedagogia nos sugerem entender que arte é expressão, conhecimento, um modo de organizar os conhecimentos de forma sensível e criadora - e estes aspectos não estão fora dos sujeitos, estão inerentes a ele. As práticas educativas em arte possibilitam a expansão da construção desse saber. Sabemos que a arte também é parte de nossa memória, também vem de relações que construímos durante nossa existência no mundo. É trabalho, é conhecimento disposto em diversos aspectos. É um campo aberto que não se limita aos museus. Desde a pré-história, por exemplo, mulheres e homens buscam expressar e narrar suas experiências através de marcas, vestígios, criando linguagens, conhecimento e expressões. Por isso, é bastante plausível a indagação de Priscila de que a arte não está apenas nos museus, mas que, assim como propôs Hélio Oiticica, o museu é o mundo. ${ }^{38}$ Ora, pensar a partir dessa perspectiva é excluir a arte que é produzida nas ruas, fora dos centos urbanos. Trata-se de um pensamento de caráter elitista incapaz de reconhecer aspectos da cultura popular, por exemplo, ou de saberes construídos fora das instituições formadoras de artistas. É um não reconhecer de que a arte é inerente ao ser humano.

38. O artista Hélio Oiticica defendia que o museu é o mundo, é a experiência cotidiana. Ver referência em: O museu é o mundo - arte e vida cotidiana na experiência de Hélio Oiticica. TESSLER, Elida Starosta. Rio de Janeiro: Azougue, 2012.
2.3.4. Você vai de corpo inteiro, porque é assim que as crianças criam

A reflexão sobre essa ótica a respeito da arte como campo aberto de possibilidades cria nessa professora uma relação singular com a sala de aula. Ela passa a enxergá-la como um espaço de invenção, de questionamentos e de pesquisa que a auxiliam a fomentar suas buscas e caminhadas pela expressão infantil:

As crianças transcendem tudo: estava estudando planetas com meu grupo e levei umas referências de Ernesto Neto e Hélio Oiticica. Duas alunas chegaram. Uma delas viu a instalação do Hélio que parece uma cama, tinha uma pessoa dentro deitada. Então, perguntou: "e se a gente colocasse isopor"? (ela queria fazer um planeta isopor).

Podemos colocar bolinhas de isopor, podemos fazer uma meleca. As crianças agora estão muito ligadas em questões sensoriais. Então eu indagava: "como é o chão desse planeta? Como é a sensação do toque nesse planeta?" E ela respondia: "o planeta isopor é o planeta que fica há 500 bilhões de anos luz." Você vai entrar nesse planeta e vai sentir como é o corpo desse planeta. Você vai de corpo inteiro, porque é assim que as crianças criam.

Eu sou mestre em Sociologia da Infância, venho trabalhando com B.J. Duarte e Mário de Andrade, desde a minha iniciação científica. Essas são as referências, junto com tantas outras, que me fizeram pensar a infância, a arte, a educação e a cultura de forma integrada. Desde a minha iniciação científica, venho tentando entender as crianças. Depois disso, observei as crianças nos Parques Infantis e esse foi o tema do meu mestrado. E no meu mestrado observava as manifestações artísticas das crianças; então, são as crianças que estão pintando, desenhando, fazendo marcenaria. Isso tudo vem do Mário de Andrade enquanto diretor do Departamento de Cultura.

Mário vem de um grupo de intelectuais que acreditava que as transformações da sociedade passavam pela cultura. Os modernistas acreditavam que a arte tem que servir socialmente porque, se o artista está num pedestal de marfim, ela não serve de nada. Arte transforma, ela serve à sociedade e, por isso, tem que estar espalhada pela cidade, não só dentro de museu. Todas as pessoas, mulheres, homens, crianças, meninas e meninos precisam ter contato com arte, onde quer que eles estejam.

Mário fez as bibliotecas circulantes, ele tinha concurso para desenhos infantis e metade era de safadeza (risos). Ele era um colecionador de 
desenhos de criança. No IEB (Instituto de Estudos Brasileiros) tem a coleção de desenhos que ele ganhou das crianças. Para ele, era muito importante que a criança estivesse em contato com a cultura. Que ela conhecesse desde Nau Catarineta à Congada. Quando saía das expedições, registrava e fotografava. As fotos das expedições são lindas, do Nordeste ao Norte. E ele traz isso para os parques porque as crianças precisavam conhecer isso, uma vez que faz parte da cultura brasileira. Uma coisa muito bonita que ele traz e diz é que: a cultura brasileira ganhou caráter de eterna; ela não morre nunca pelo gesto da criança. Então a criança é uma mensageira dessa cultura, traz isso. Isso me ajuda a me constituir como professora. As crianças entrarem em contato com isso, é importantíssimo. Nossa cultura, as brincadeiras populare e as danças. A cultura não vai morrer pela criança, nesse período que a gente está vivendo de incêndio em museu. A criança terá acesso à informação, internalizará do jeito dela, com o movimento dela: a cultura não morre porque passa pela criança. É isso que eu venho estudando, esse mergulho na arte; eu não sou artista, mas acredito na arte como meio de transformação da sociedade. E isso muito pelo gesto da criança.

Priscila, apesar de não vivenciar corporalmente nenhuma linguagem artística, mergulha de cabeça e de corpo inteiro no campo da Arte. Apaixonada pela cultura infantil, encontra nas expressões das crianças, nas fotografias de J.B. Duarte, nos escritos de Mário de Andrade, nas produções artísticas de Hélio Oiticica, por exemplo, a possibilidade de ampliar seu repertório como professora-pesquisadora e criadora. Entende que a arte é uma manifestação fundamental para a constituição social, para a constituição de si, de seus estudantes, e para impulsionar transformações.

Sua experiência pelo campo da arte está relacionada ao conhecimento historicamente produzido por diversas linguagens. Dessa forma, sua atuação é como arte/educadora, como professora criadora de possibilidades, a partir das quais as crianças vivenciam situações de aprendizagem e acontecimentos. Realiza suas práticas de modo a provocar nas meninas e nos meninos possibilidades de criação e invenções. Dialoga com os saberes de forma integrada, como o que aconteceu, por exemplo, no projeto sobre planetas. Nele, estavam colocados campos de saberes como Ciências e Arte. Podemos entender melhor como Priscila pensa sobre a criança artista a partir de duas imagens que me enviou.

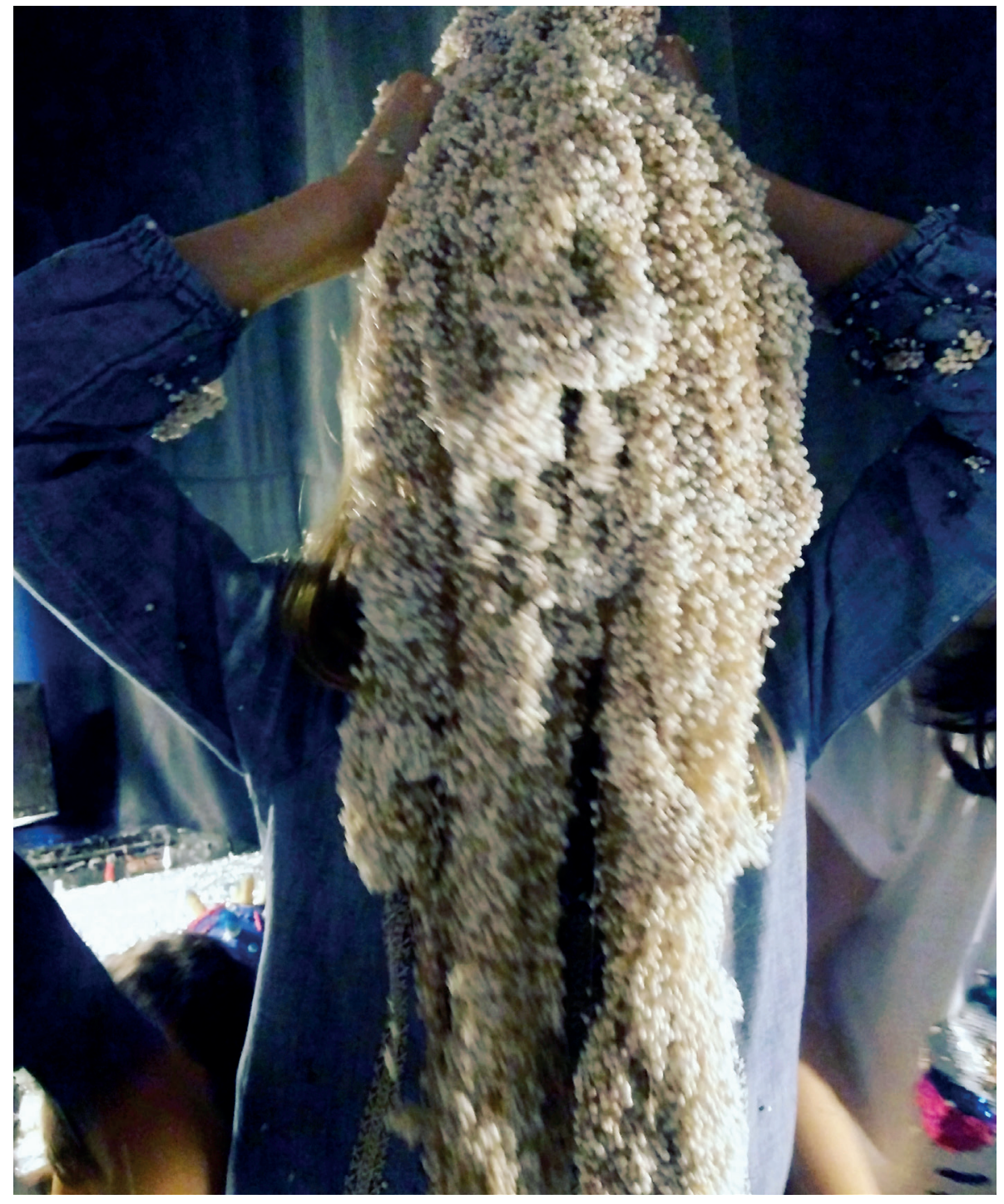

Figura 25. F., 7 anos, em seu "planeta isopor", foto de Priscila Brito a respeito do projeto mencionado acima, 2018. 
2.3.5. A criança é essencialmente um ser sensível à procura de expressão

Veja, na primeira imagem é F., 7 anos, que fica aborrecidíssima ao ver que as crianças estão vivenciando seu planeta apenas com as mãos, em uma mostra realizada ano passado em nossa escola. Para ela, o planeta deveria ser vivido intensamente, as pessoas deveriam mergulhar neste planeta, como ela o fez durante toda sua pesquisa estética, artística e brincante. Daí que ela entrou em seu planeta e mergulhou, pegou a meleca e colocou na cabeça dizendo "é assim que faz, ó", deixando todo mundo estarrecido. Afinal, como é que se coloca uma meleca dessas na cabeça? Mas é ela, a autora, a artista, a criança-criadora que mostrou como se vivencia sua obra. E isso me toca muito. É o diálogo que faço com Mário de Andrade (1929, p. 1299), quando ele diz: "A criança é essencialmente um ser sensível à procura de expressão. Não possui ainda a inteligência abstraideira ${ }^{40}$ completamente formada. A inteligência dela não prevalece e muito menos não alumbra a totalidade da vida sensível. Por isso ela é muito mais expressivamente total que o adulto. Diante de uma dor, chora - o que é muito mais expressivo do que abstrair: "estou sofrendo". A criança utiliza-se indiferentemente

de todos os meios de expressão artística."

Veja, Mário não diz aqui que a inteligência da criança é inferior. Não. Quando fala da tal "inteligência abstraideira", ele quer falar que a criança ainda não tem sua inteligência e sensibilidades podadas, cerceadas, como nós adultos. Por isso ela é mais total e, diante de uma dor, de uma música, de uma brincadeira, expressa-se de corpo inteiro, sem parar para abstrair, pensar sobre aquilo que está vivendo. Seus processos criadores são muito mais totais e sensíveis. A essa frase de Mário, eu acrescentaria: diante de um planeta, mergulha.

O desenho é de L, 6 anos, que o fez após a conversa que propomo com um professor do ensino médio, que veio nos contar sobre o universo. Fez parte de nossas pesquisas. Não separamos ciência-arte-

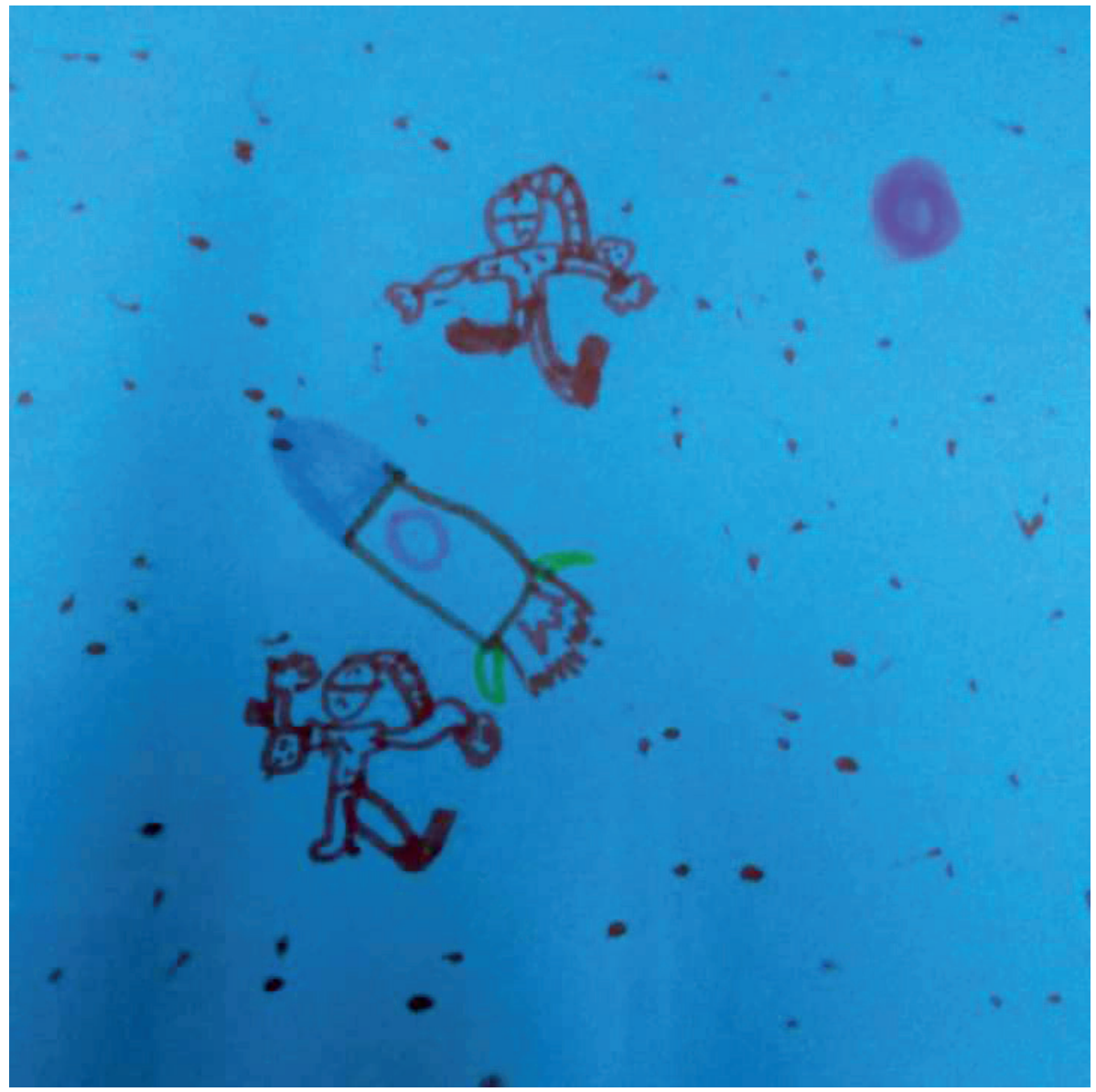

Figura 26. Desenho referente à pesquisa de planetas narrado por Priscila a cima de L, 6 anos, 2018.

39. Este trecho foi escrito por Priscila ao me enviar suas imagens, sendo assim, ela reflete de maneira profunda as experiências artísticas vivenciadas por suas estudantes.

40. Mário de Andrade em 1929 escrevia crônicas para o Diário Nacional; na crônica intitulada Táxi: Da criança-prodígio - I, diz que as manifestações das crianças não podem ser atingidas pelas forças abstraideiras, ou seja, a inteligência. Ver em: Mário de Andrade, Táxi e Crônicas no Diário Nacional. Estabelecimento de Texto, Introdução e Notas de TelêPorto Ancona Lopez. São Paulo: Duas Cidades, Secretaria da Culucura e Tech 1974. 
-brincadeira-poesia. Esse desenho conta deste percurso também. As imagens são as duas pontas deste processo.

Aspectos singulares e (trans)formadores das experiências vivenciadas por Priscila em suas andanças pela educação, arte, pesquisa e escola, mostraram-me outros possíveis para se pensar as experiências em arte e a forma como as professoras levam tais experiências para suas práticas educativas. Ela se mostra uma professora de grande sensibilidade, uma professora que, buscando a comunhão com seus estudantes, encontra uma forma de olhar as criações infantis como potência de saberes. Respeita, dialoga e possibilita que suas alunas e alunos possam experienciar proposições e poéticas de ensino. Cria ambientes capazes de relacionar saberes, impulsionando um aspecto questionador e investindo muito em seus alunos. As crianças, ao se depararem com suas produções, como foi o caso de F., sabem exatamente o que estão criando, sugerem a relação, falam de si e de seus desejos. Priscila se reconstrói constantemente junto com seus estudantes e sabe que em tempos sombrios como os nossos, onde museus são queimados ${ }^{41}$, podemos construir outros horizontes a partir de nossa relação com as crianças - mensageiras no/do nosso tempo.

41. Priscila está se referindo ao incêndio no Museu Nacional na Quinta da Boa Vista, Rio de Janeiro, na noite de 2 de setembro de 2018. A tragédia ocorrera pouco antes de realizarmos a entrevista.
2.4. LETÍCIA: AS ANDANÇAS, MUDANÇAS DE ROTA, FUGAS E PRÁTICA DOCENTE NA CONSTRUÇÃO DE SI

Como as demais colegas, Letícia também chegou em casa após o trabalho. Até 2018, éramos professoras de alguns alunos em comum. Naquela altura, passava as manhãs com eles realizando proposições em arte e, quando chegava a tarde, as crianças iam para a escola no ensino regular encontrá-la. Enquanto preparava um chá para iniciar a entrevista, trocávamos algumas impressões a respeito de nossos estudantes. Essa prática é bastante habitual em nosso convívio. Realizamos essas trocas em muitas instâncias e tê-la como parceira no dia a dia é algo que me auxilia de forma bastante construtiva. A meu ver, não se faz educação sozinha mas, sim, em relação e em comunhão com os pares. Por essa razão mais do que fundamental, trago Letícia a esta escrita.

Letícia foi desenhando seu trajeto e os caminhos até chegar à Faculdade de Educação. Eu não tinha dimensão desse percurso. A dúvida mobilizou sua escolha. Ela, por sua vez, passou por afetos familiares. Neta, filha e afilhada de educadoras, procura ocupar esse espaço à sua maneira, construindo-se e indagando sobre as experiências em Educação.

Eu não decidi o curso com muito tempo de escolha, ou totalmente assim, não sei o quanto foi uma escolha real e pensada. Na verdade, ao contrário, indecisa, não sabia o queria fazer. No meio do terceiro ano, tinha prestado Turismo na Unesp, passei, só que era no Pontal de Paranapiacaba e por isso acabei não indo. Prestei Administração e Turismo de novo, estava bem perdida. Só que tenho um histórico na educação um tanto familiar: as minhas duas avós foram professoras, a minha mãe é uma pessoa extremamente fissurada por educação, mas é uma professora frustrada. Fez física, parou no meio e foi cursar História, se formou e sempre quis ser professora, mas não deu muito conta. Foi para rede pública trabalhar com adolescente, muito nova e não deu conta emocionalmente disso. Então a minha mãe tinha uma coisa muito forte com a educação. A minha madrinha é professora da Unicamp, foi coordenadora do curso de Pedagogia, a Maria do Carmo Martins, a Carminha. Ela também é da história e foi trabalhar com História da Educação. Todos os amigos da minha mãe são professores, pensa: formados em Física e em História. Minha mãe sempre admirou muito isso e por muito tempo ficou mais nela do que em mim. Quando eu fui prestar vestibular, durante o cursinho, estava muito indecisa e minha mãe começou a pegar no meu pé: "vai prestar Pedagogia." Eu sempre tive uma coisa com criança, sempre gostei, mas sabia que não era uma coisa de recreação. Eu sempre gostava de criança até a página dois: "como eles são fofinhos, não." Eu gosto desse convívio, e 
aí minha mãe falava: "vai fazer pedagogia, você leva jeito, você gosta". Meu discurso era exatamente o oposto, eu gosto de criança, mas não me vejo educando, não me vejo nesse lugar, de todos os dias, educando. (...) Eu fui muito, ah, tá bom. Não era um sonho.

Desse jeito, Letícia adentra ao curso de Pedagogia, escolhe essa trajetória sem ter muita certeza, embora desde aquele momento tivesse uma reflexão a respeito da relação que ia estabelecer com o universo infantil; ela, como viajante, deporta em um lugar em que, embora existissem referências fortes, não fazia ideia do que iria encontrar.

\subsubsection{Pela prática eu me apaixone}

E entrei... Só que comecei a trabalhar muito rápido. Na verdade, eu cursei seis meses sem trabalhar. Lembro que vi um anúncio para fazer entrevista no Colégio Oswald de Andrade na quinta-feira e já fui na sexta-feira fazer entrevista. Comecei a trabalhar na semana seguinte, sempre foi junto e, na verdade, é o que me manteve na educação, porque pelo curso em si eu não me apaixonei. Achei o curso enfadonho, havia professores bons mas, no geral, não era uma coisa que super me mobilizava. Tenho dificuldade com o estudo, não sou uma pessoa regrada, é dificil esse discurso mais acadêmico. Mas pela prática eu me apaixonei.

Letícia teve uma experiência singular na universidade, não foi o curso de Pedagogia que a mobilizou para refletir e indagar situações a respeito da educação, mas, sim, a prática docente. Ambas as formações acontecem conjuntamente. Escolhe, portanto, percorrer essa viagem dessa maneira, passando despercebida pela universidade e fincando suas energias no trabalho. Extraindo dessa experiência docente a substância para sua constituição como professora.

Nunca frequentei a USP, não tinha essa relação e sempre atribuí isso a estar trabalhando. Trabalhava à tarde e fazia o curso noturno e sempre foi muito corrido. Chegava na faculdade em cima da hora ou atrasada porque às vezes pegava muito trânsito, sempre muito cansada. Ia, assistia aula, e ia embora. Mesmo no dia a dia, era um tanto difícil fazer trabalho em grupo, era uma coisa bem pragmática. Na verdade, comecei a ter um grupo na faculdade quando encontrava as professoras do meu trabalho no curso; foi de fora para dentro, não ia em festas, não tive isso. Eu tinha preguiça de um certo discurso, depois as pessoas vão ficando mais interessantes, mas era muito marcante no começo esse discurso: "ah porque criança é fofa." "Vim fazer pedagogia porque adoro criança." Tinha vontade de dizer: "Então, sai". Se você adora criança, vai parar de adorar, não é esse caminho.

Para mim estava claro que fui fazer a Faculdade de Pedagogia porque adorava a educação. Da relação que eu estabeleço com as crianças, criei vínculo com meu grupo, porque essa relação é de afeto e ela transborda uma série de coisas. Para mim, sempre foi essa coisa da educação, que muitas vezes é chata, é difícil, tem problemas, tem criança que é chata e até é esse o desafio. O que eu faço com uma criança que tenho dificuldade de me aproximar?

Essas questões passam pela discussão e pelas reflexões a respeito do curso de Pedagogia. Eu também vivenciei essas discussões em sala de aula durante a graduação, sentia falta de discussões mais profundas; esse discurso, muitas vezes idealizado da infância, afasta um entendimento mais profundo, por exemplo, das relações sociais que cercam a infância - de sua constituição histórica, dos meios onde habitam e que as vão auxiliando na formação de pensamento, impulsionando-as a criarem culturas e expressões. O trabalho a mobiliza a buscar novos horizontes formadores e cria questionamentos sobre o devir professora.

Trabalhei no Colégio Oswald de Andrade até o final de 2009. Estava no segundo ano, tranquei a faculdade e fui para Espanha estudar seis meses. Fiz a Universidade de Salamanca, escolhi pela internet as matérias que eu queria fazer. Fui para estudar duas disciplinas de Educação Inclusiva; na época, estava muito latente porque no antigo trabalho lidei muito com inclusão e, como professora auxiliar de sala, isso acaba ficando muito por nossa conta. Uma disciplina era de inclusão mais geral e uma era de inclusão de paralisia cerebral, surdos e mudos. (...)

Fiquei um semestre, voltei para a USP, me matriculei em oito matérias não trabalhei até outubro. No final do ano, no entanto, pintou uma substituição no Colégio Vera Cruz como professora auxiliar. Finalize o ano e em novembro fiz a entrevista na escola Estilo de Aprender. ${ }^{42}$ Entrei como professora de Grupo 4 em janeiro e, em maio, assumi o primeiro ano da tarde.

42. A escola Estilo de Aprender está localizada na cidade de São Paulo, tem 17 anos e possui Educação Infantil e Ensino Fundamental I. 
O desenho de seu percurso na universidade é potencializado em sua experiência escolar. Narra com relevo suas andanças pela escola, talvez, por ter tido essa experiência de forma bastante latente. Desde o primeiro ano de graduação, torna-se professora de sala antes mesmo de ter concluído o curso. A universidade, para ela, não foi uma experiência fundante, construtiva e que a possibilitou alçar voos para vislumbrar novos horizontes. Se não a mobilizou profundamente, ainda assim foi uma experiência relevante, ainda que nem sempre acontecem correspondendo às expectativas positivas. Podem também deixar marcas que causam indagações, críticas e que levam o pensamento para outro lugar. Concluir o curso foi o ponto de partida para que ela pudesse viver outras possibilidades. As experiências são singulares, únicas e passam pelo nosso corpo, nos (trans)formam. Letícia encontra na escola, portanto, a sua formação mais importante na construção do seu devir professora.

2.4.2. Um caminho para o campo da arte foi a escola

A hora que terminei, veio um: huhu, terminei e nunca mais voltei (...). Foi a relação com a prática que me fez pedagoga. De memória não tenho nada, uma aula que me marcou, um texto e um professor. Foram poucas as experiências de encantamento. Fiz todas as matérias que pude fazer com a professora Rosa Iavelberg, a obrigatória e duas optativas. Teve uma disciplina de construção de portfólio, para mim isso foi muito importante, não tinha experiência com arte, mas tinha essa vontade (...). Em cada aula, propunha uma prática e íamos arquivando essas experiências - desenho e alguma reflexão sobre a relação com um artista.

O que me despertou um caminho para o campo da Arte foi a escola. A Estilo tem muito essa pegada, a minha coordenadora tem e lá aprendi a mexer com isso. Fui afinando meu olhar, era uma demanda profissional, sempre que eu fazia uma reunião de trabalho para pensar um tema, já vinha uma série de referências artísticas, era uma coisa latente na coordenadora e na escola. Isso era uma coisa que já dominava a reunião: "- Lê, sobre esse assunto tem um gravurista maravilhoso, procura lá". Isso era uma coisa, um rebuliço no estômago, quase ver a coisa tomar forma. Tanto é que eu lembro de uma experiência com um grupo de segundo ano: fiz um trabalho que chamava artistas espanhóis. Um semestre estudando o Gaudi, Miró, Picasso e Dalí. Esse tema foi muito marcante, era um mergulho meu, ficava estudando a biografia, a obra, para contar para as crianças. Mexer com arte é uma coisa que eu trago o tempo inteiro depois disso. No São Domingos fiz o tema dos retratos e me perguntava: como esses artistas fazem esse retrato, qual a técnica? É algo que eu gosto muito.

Em Letícia é muito forte a consciência de que foi a relação com a prática que a fez professora. Tanto que essa relação é o assunto predominante durante a entrevista. É a força que ela encontra para sustentar seus percursos formativos, é o lugar que pediu passagem para constituir seu corpo pensante como professora. São as situações de aprendizagem, a relação intensa que estabelece com seus estudantes que marcam sua trajetória docente. São nessas experiências que ela busca processos formativos e onde encontra ressonância com o campo da arte/educação. Esse campo se faz importante na mesma medida em que é capaz de relacionar os conteúdos trabalhados com as demais áreas do conhecimento, transitando pelas diversas linguagens artísticas e, sobretudo, pelas artes plásticas.

Nesta altura, Letícia é absolutamente capaz de refletir sobre questões que cercam a prática educativa, o lugar da arte na escola e a importância de desenvolver um pensamento formativo a respeito da arte na pedagogia.

2.4.3. O campo da Arte é onde me pega e está na sala de aula o tempo todo

Na Estilo não tem especialista de Arte, isso tudo fazia parte do tema de investigação do grupo. Lá tem uma configuração de que, na Educação Infantil, há um especialista de música e capoeira, formando um conjunto. Agora, na minha prática, acho legal ter esses especialistas mas o tempo inteiro. Sempre busco dialogar com as professoras de arte mas é isso, tem que ficar o tempo inteiro fazendo esse exercício de costura. O campo da Arte é onde me pega e está na sala de aula o tempo todo.

Essa questão a respeito das atribuições das professoras da Educação Infantil como, por exemplo, terem de dar conta de inúmeras demandas incluindo as aulas de arte, já havia aparecido na narrativa de Carolina. $\mathrm{Na}$ rede privada, em alguns exemplos, há professores especialistas em arte; no entanto, isso não é uma regra. Em alguns casos, há professores apenas de música e corpo, atribuindo a docência de artes plásticas à pedagoga responsável pelo grupo. São problemáticas profundas que dizem respeito à formação inicial do curso de pedagogia. Por mais que exista uma aproximação de muitas pedagogas ao campo de experiência em Arte, ministrar aulas, transformá-las em conhecimento, estudo e proposições de pesquisa de linguagem aos estudantes, é algo bastante complexo. Para que tal aula se realize de forma profunda e consistente, é preciso subsistir, por parte das professoras e professores, o conhecimento do fazer sobre as linguagens 
trabalhadas. É preciso que as pedagogas e pedagogos tenham vivenciado experiências no campo da Arte pois, apenas dessa maneira, pela mente e pelo corpo transpassados, poderiam entender como transcrever esse saber em cognição. Criar experiências no campo da Arte aos estudantes, passa também por tê-las vivenciado. Se a professora ou o professor domina uma linguagem artística, passa a entender as dúvidas, os desafios e as apropriações do material e das linguagens. Embora, em muitos casos, exista a compreensão do quanto esse campo de saber é fundamental para a sala de aula - pois as crianças pulsam em expressões que buscam realizar pelo desenho, pela brincadeira e pelo corpo -, encontramos muitas dificuldades em proporcionar experiências de fato significativas à nossas alunas e alunos.

De todo modo, como as demais colegas, Letícia busca encontrar ressonâncias no campo da Arte. Encontra sua linguagem, seus desafios e incorpora a importância de estabelecer um diálogo constante com as linguagens artísticas. Nesse caso, mais especificamente com as artes visuais. Encontra problemas e indagações na realização do trabalho educativo e busca, de maneira singular, um caminho para trilhar esse conhecimento.

O tema dos retratos foi bastante significativo: era um grupo com muitas demandas sociais, pessoais e sempre penso nisso (...). É engraçado como a coisa se costura agora. Pensando bem, é a minha linguagem. Eu tinha instintivamente, fundamentei a ideia de trabalhar com retrato como a ideia de um caminho para olhar para si e para o outro (...) Trabalhar com retratos para olhar para dentro e para fora. Agora, tem um milhão de possibilidades para você fazer esse trabalho.

Neste momento, por exemplo, tenho trabalhado personagens bruxas e vou pensando o que é importante para esse grupo. Quando vejo, estou eu lá falando das mulheres artistas contemporâneas.

2.4.3. Desenho das crianças, é uma coisa que me mobiliza, que sinto falta de trabalhar

Eu tenho algumas questões de como o desenho vem sendo trabalhado e como a escrita toma esse lugar. Acho que é um grande desafio de todas as escolas. Por mais exercício que se faça, que a gente fale, é raríssimo você ver um lugar que coloca o desenho e a escrita no mesmo patamar. É socialmente construído, a criança já coloca, logo que ela começa a escrever, até antes. Lembro-me quando trabalhei em um grupo, justamente nesta transição. Assim que eles começam a se aproximar das letras, não é que eles rejeitam o desenho, mas isso toma mais espaço. Não sei dizer o quanto isso é natural, institucional, acho que tem um pouco a ver com esse novo conhecimento. A escola praticamente faz e fomenta esse lugar. A criança já está querendo muito aprender a escrever, ela sabe que dessa maneira ela acessa um outro universo: "eu quero entender o que os adultos escrevem".

Sim, a escola entra exatamente neste momento dizendo que tem que escrever, é preciso escrever, escrever lindo... Afinal, é o papel da escola. Para mim, essa balança é muito difícil. Já entrei em muitas crises, muitas, muitas e muitas. Para a escrita, eu sabia pensar estratégias para deixar ela entrar de um jeito mais fluido, mais orgânico e que fizesse sentido (...). É dificil, porque tem momentos que dói e escrever dói. No final, fazer sentido vai fazer, a gente cria sentido, a gente sabe disso. Se a gente quer que alguma coisa faça sentido para o grupo, a gente vai fazer sentido. Esse lugar do sentido muitas vezes é autoritário, porque vai fazer, mas será que esse sentido vai refletir a necessidade real do grupo? Essa é uma pergunta.

Talvez, pensar o lugar que a arte ocupa na escola nos ajude a refletir sobre as questões que Letícia aborda. Aqui, defendemos que a arte é conhecimento, que ela constitui a expressão e que é uma atividade inerente à infância, mas que, ao longo do processo escolar, ela vai se perdendo diante das demandas institucionais. Esse não é um problema localizado em tal escola mas, sim, um problema localizado no modo de pensar a escola e em como vão se desenhando os currículos escolares. Quando se coloca a escrita como algo mais importante que o desenho, tolhe-se a possibilidade de um desenvolvimento profundo dessa linguagem, que também solicita pesquisa, desafios e cognição. Nos currículos escolares, predominam as demais áreas do conhecimento, tais como Língua Portuguesa, Matemática e Ciências, e elas acabam ocupando um lugar de hierarquia; ou seja, são compreendidas como mais importantes que as linguagens artísticas. Os dados narrados pelas professoras, em situação de sala de aula, refletem uma necessidade diferente.

Conforme as crianças vão crescendo e avançando em suas vivências escolares para as séries do Ensino Fundamental I, vão perdendo a relação com o fazer artístico e brincante. É uma imposição à subjetividade que passa a operar em outra lógica e isso também diz muito respeito à fragmentação que se realiza na grade curricular. Não se pensa um currículo escolar onde as linguagens possam ter a mesma equivalência de importância, pois todas elas nos constituem enquanto sujeitos, criadores e formadores do processo de aprendizagem. Seria um processo urgente a se pensar, dar um peso equivalente a todas as áreas do conhecimento. Da mesma forma, pensar a formação inicial de modo que os estudantes de pedagogia possam não apenas discutir metodologias em Arte mas, igualmente, vivenciar experiências nesse campo de forma integral. 
Letícia foi encontrando um modo bastante singular para atuar e se relacionar com o campo da Arte nas suas práticas em sala de aula. A partir desse trabalho, ela desenvolve questões, reflete e desenha os mapas de seu percurso educativo.

Escolhemos vários retratos e perguntamos para as crianças. E as crianças, ao olharem os retratos, começaram a experimentar da sua forma. Desenhavam um tubarão, depois o faziam com tecido, outras possibilidades foram acontecendo (...). Mas está muito associado, para mim, a ideia de que foi um tema importante, mas foi um tema importante para mim, e esse tema atravessou muitos processos individuais. O olhar sensível parte pela arte, porque a arte convida a isso, convida para outro lugar.

De repente, as crianças começam a fazer o seu retrato, o retrato do outro, percebem seu traçado e dos detalhes dos desenhos. Só que o grande lance desse grupo era uma coisa de olhar para o outro. Sobretudo não conseguir identificar e falar sobre o que sente. Então, na verdade, era um pouco isso, a gente fez um trabalho com os retratos para conseguir chegar e olha para outra coisa e para o que se sente: "Ele está triste? Está feliz? Está com fome?" A gente brincou muito com isso o tempo inteiro: "e como a gente representa? Por que a gente foi por esse lugar também, que cor eu uso para colocar uma pessoa triste? O que eu faço para tentar mostrar quando eu quero desenhar uma pessoa com fome?" Tanto é que a gente terminou construindo um jogo, o super-trunfo. Era uma carta de cada criança, eles encaram os critérios: alegria, tristeza, criatividade, mas eram critérios totalmente subjetivos. Depois disso, cada um se numerou: "De um a trinta acho que sou vinte e cinco alegre, acho que sou três triste", sabe? Mas até chegar a essa numeração, tinha todo um trabalho para entender o que é ser triste e o que é ser alegre. Como eu represento isso? E que não estava na fala, não ia passar pela fala, não estamos falando de uma racionalidade adulta (...): "Vamos estruturar o desenho, vamos pensar o desenho, reconhecido dentro de cada possibilidade". Uma professora da graduação falava da criança com muito conhecimento desenhista e da criança com pouco conhecimento desenhista. Por isso, acho importante fazer alguns trabalhos de formalização, não aquele superficial. $\mathrm{O}$ desenho da figura humana é super importante. Ele é expressivo, ele é constitutivo, é um trabalho que precisa ser feito na educação infantil, por exemplo. É um trabalho profundo, não é qualquer coisa. O desenho palito me assusta porque para mim é como se a criança tivesse desistido da figura humana. Quando trabalhei com as crianças em exemplo, as crianças realizam desenhos de outro mundo, cuidadosos, você vê sequência de temas, de pessoas, é uma pesquisa. É o momento de elaborar esse traço próprio; então, muitas vezes, eu nem preciso pôr nome no desenho, só pelo traço já sei quem fez. E esse desenho de figura humana, ele vai tomando uma forma muito particular da criança. Só que aos cinco anos, essa mesma criança vem com homem palito. Aí eu pergunto: "o que aconteceu?" Acho que é porque entra essa coisa do certo e do errado, do feio e bonito.

Esse ponto da narrativa é de grande valor para pensarmos a importância de se trazer uma composição mais orgânica entre os campos de conhecimento. $E$ a escola tem muitos papéis em relação à construção dos saberes. É fundamental desenvolver com os estudantes saberes como olhar para si e para o outro, expressar os sentimentos e desenvolver relações com diversos assuntos e com as diversas singularidades. Pensar que a matemática pode aparecer em um jogo construído pelas meninas e meninos a partir de como se sentem, por exemplo, pode possibilitar que os estudantes reflitam sobre si, sobre a relação que estabelecem com o mundo e com o outro. As crianças aprendem formas de expandir esse conhecimento, de criar situações, por mais desafiadoras que elas possam ser. A escola é o lugar do desafio, da dúvida, de se deparar com o erro, com o difícil. Mas é também o lugar do sensível, das relações humanas. Esses aspectos fazem parte de processos impulsionadores de criação e invenção dos saberes.

O desenho não é apenas uma livre expressão infantil, embora em alguns casos ele também se faça partir dessa camada, mas é na escola que ele vai gerar pesquisa, conhecimento, narrar histórias, criar uma linguagem própria e singular. O desenho é conhecimento, aprendizagem e profundidade de expressão da forma como a criança está se relacionando com o mundo que a cerca.

\subsubsection{Um lugar para fugir da escola}

Eu queria muito voltar a estudar, a me mobilizar de algum jeito, e eu sentia que precisava olhar para outros lugares, para fora da escola, para fora da minha prática. E eu não queria nada de pedagogia, ma de jeito nenhum, não conseguia me ver fazendo uma pós-graduação sobre alfabetização, nem sobre desenho infantil, não me via neste lugar. Eu queria uma pós-graduação que me alimentasse como pessoa e óbvio que isso vai e foi para sala, mas eu não conseguia imaginar fazer esse estudo que não me alimentasse como pessoa (...). Eu entendo que é importante você procurar uma formação dentro do que você faz, é 
o caminho natural. Mas eu estava em fuga e foi muito louco porque eu estava tão em fuga que passei um ano e meio na pós me recusando veementemente a misturar as coisas. Para mim, naquele momento, era impensável levar a escola para a pós e a pós para a escola. Porque eu estava nesse lugar buscando meu espaço, eu vim para me alimentar, para eu respirar, para eu olhar o mundo de outro jeito, para eu me encontrar em outro lugar. Então, na pós, eu convivi com muitas professoras de arte e, em vários momentos, os trabalhos que elas levavam eram trabalhos realizados com grupo, trabalhos que eram propostos na escola, e isso é natural. Lembro que até em um dos encontros eu falei exatamente isso: "eu não quero misturar, eu quero trazer para cá alguma coisa que seja minha". Entendo que não é que a escola não seja minha. É que naquele momento eu precisava de um outro lugar, um lugar para fugir da escola. Porque eu acho que a escola nos toma muita energia, muita emoção, e até para dar conta de ter muita energia e muita emoção eu precisava de um outro respiro. Estava até outro dia comentando com alguém: nossa, como o corpo dói, cansa, mas essa educação é a que eu acredito. Acredito nessa educação que vai me atravessar, que vai passar por dentro de mim. Se não for assim, eu penso em outras alternativas.

Letícia procurou uma pós-graduação em arte/educação. É fundamental que professoras e professores possam buscar expressões que não sejam voltadas apenas para suas práticas educativas. Também faz parte da constituição humana, subjetiva e sensível, os lugares e pontos de fuga, brechas e fendas que ocupam os vazios deixados. As experiências em arte, fora da escola, fora dos processos formativos voltados para a formação educativa, podem trazer esses lugares. São frestas, como Letícia chamou duas fotografias que tirou em um de seus percursos formadores.

Dizia ela:

Enxergo caminhos. Por mais que sejam trilhos, são vários diversos e possíveis também de caminhar a pé, transgredindo-os. E são vistos pela fresta, que já é um atravessamento, entrada, ruptura, possibilidade. O não-convencional, o inusitado! As arquiteturas transformadas pelo tempo. Parecem rígidas, mas ainda assim são passíveis de entrada... É desse encontro que se amplia nossa prática poética.

Pensar nossa formação inicial como a criação de possibilidades em que pudéssemos voltar para nos conhecer, nos relacionar com nosso corpo com nossos traços, com a rigidez, com os vazios deixados pelos modos de existir, saber passar por eles, por mais apertados que possam ser - talvez nos ajudasse a romper certas barreiras, do olhar para os processos apenas pelo viés do acerto, do erro paralisante, da dualidade entre bonito e feio e

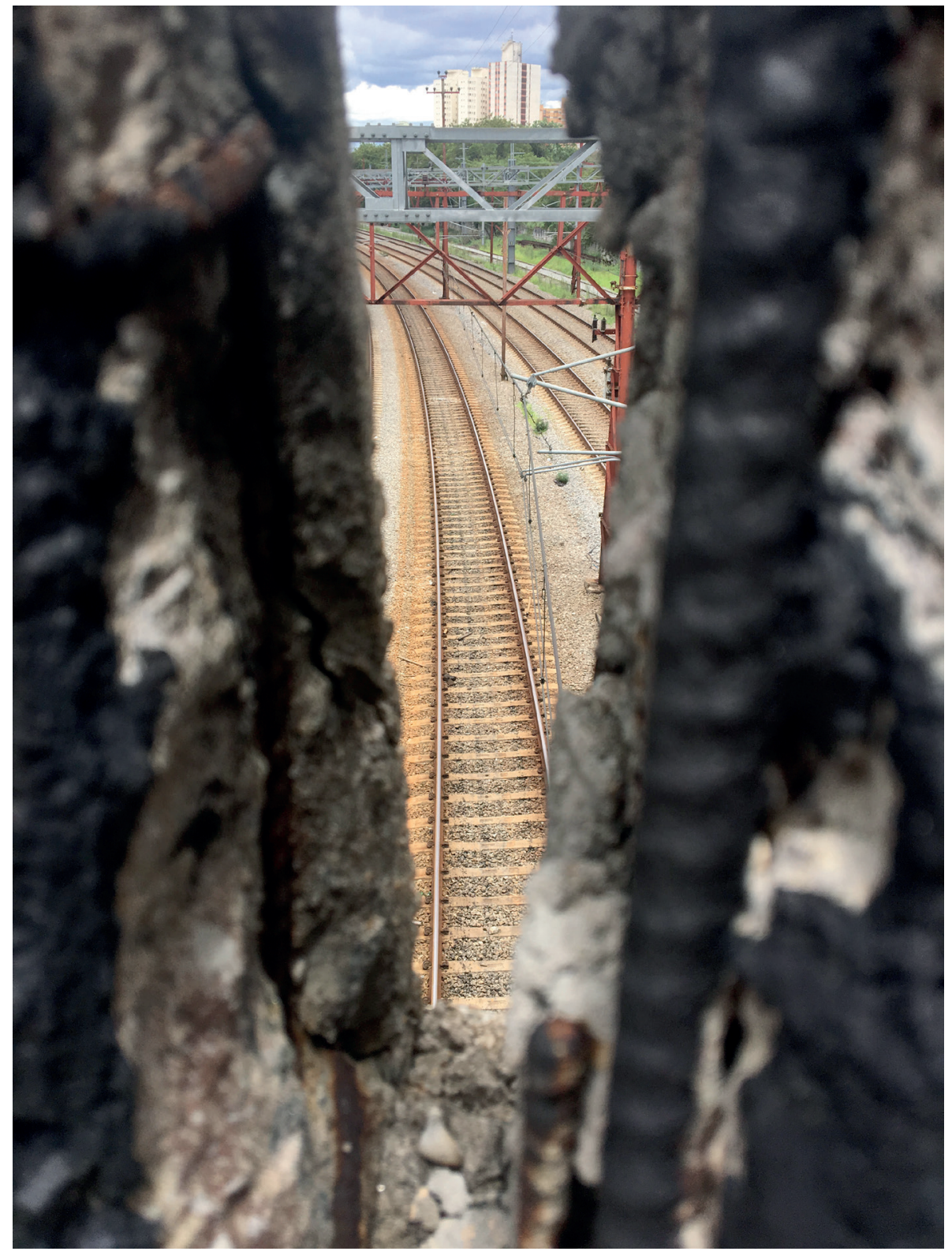

Figura 27. Fresta I - fotografia enviada por Letícia Mello para expressar suas pesquisas, 2018. 


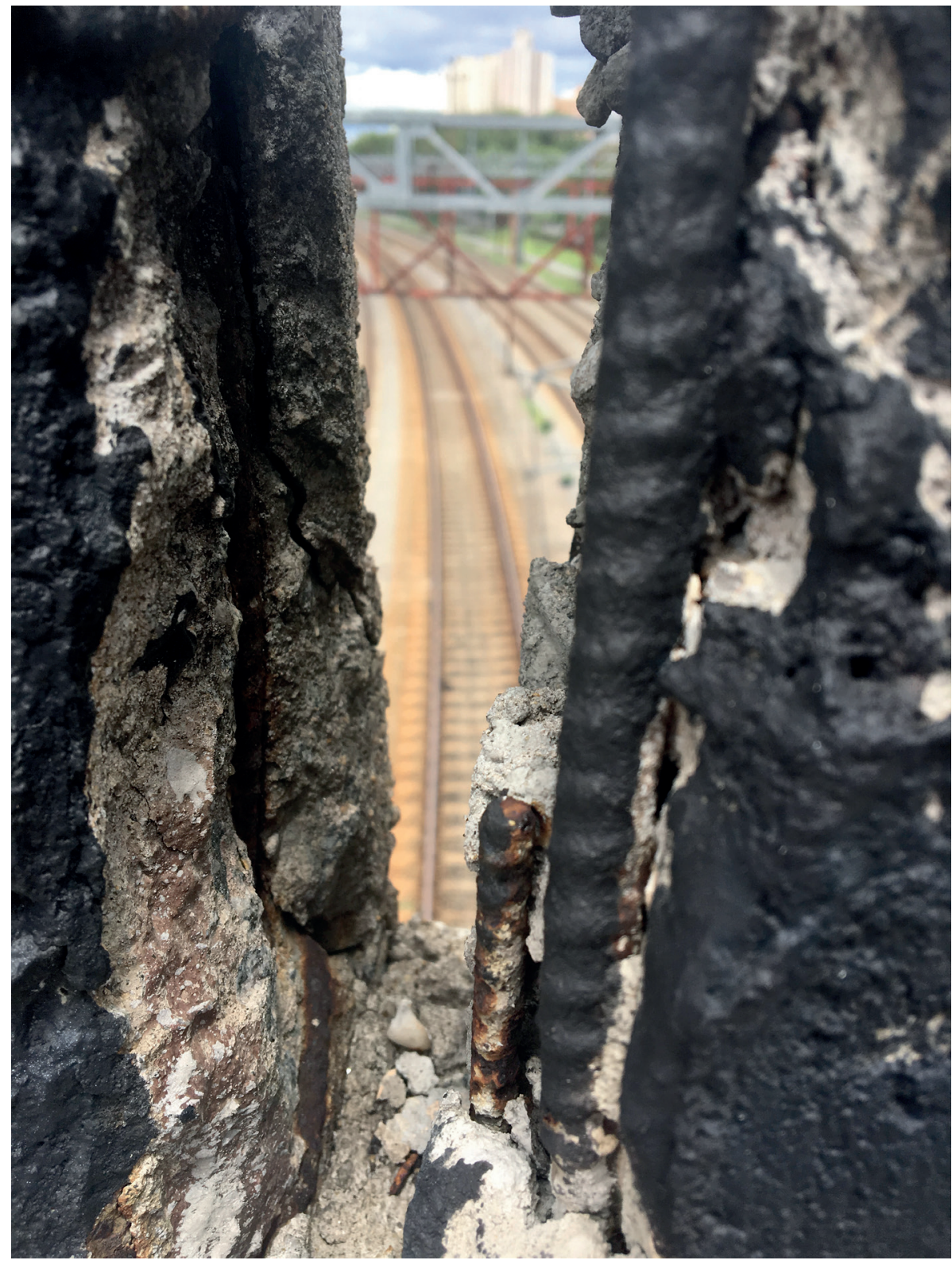

Figura 28. Fresta II. Letícia Mello, 2018. das caixinhas segmentadas nas quais vamos guardando nossas experiências. Como professoras, escutamos e observamos que, em muitos momentos, nossos alunos transgridem essas barreiras, nos mostram outras situações e possibilidades de conhecimentos. Nos impulsionam a nos reconhecer neles, a nos observar. Quando em comunhão, nossos limites e fissuras ficam aparentes e nos fazem querer continuar navegando, andando e procurando outras maneiras de formar, de criar, buscar novos conhecimentos e aventuras. As crianças nos possibilitam outras maneiras de olhar a vida, pela via sensível, pela atenção e percepção de si. Assim, Letícia vai fechando a narrativa. Ela também observa nas crianças, em suas atitudes e maneiras de expressar o conhecimento, o que nela ainda é um ponto de superação. Letícia se vê criança, se repensa e procura recriar a si mesma.

2.4.6. A minha limitação esbarra exatamente na minha falta de formação em arte

E foi um processo muito difícil, eu não consigo me olhar como artista. E até agora é dificil chegar a algum lugar. Eu entendo a importância da arte, eu gosto de trabalhar com as crianças, elas falam para mim, mas é muito difícil fazer um trabalho autoral. Não consigo, tem uma trava. Eu quero e morro de vontade, tenho esse desejo, mas vivo me criticando, nunca está bom. Para você ter ideia, eu não desenho. Agora até pensei em fazer um ateliê para ver se eu experimento um pouco mais, mas eu me boicoto, me boicoto muito. Agora com o trabalho conclusivo da pós, tinha tido uma epifania: eu vou dançar. Quero dançar porque eu falo muito, e não quero mais falar, eu quero dançar. Quero ir para o corpo, mas até agora não fui procurar. Pergunta se eu fui atrás? É daqui um mês e meio e fico pensando, eu vou dançar o quê? Como é difícil, porque é um corpo extremamente castrado. Não sei o quanto isso também não reflete o que quero propor para as crianças, de tentar um outro lugar, porque eu sei que para mim é muito difícil, tentar sair disso, essa expressão artística em mim é muito difícil, um parto (...).

Letícia tem um corpo pulsante e reflete sobre uma questão fundamental: em que momento de nossa escolarização deixamos o corpo de lado e operamos apenas de maneira mental? Pensa sobre suas limitações e procura, em sala de aula, levar as crianças a outro lugar, como ela mesmo diz. Mais uma vez, aparece de forma clara a questão de que levamos para as práticas educativas situações em que observamos em nós dificuldades e que, por esse motivo, procuramos fazer o contrário com nossas alunas e alunos. As crianças se expressam pelo corpo, sobretudo na Educação 
Infantil, momento em que ainda, em alguns casos, a escolarização não está fragmentada em as disciplinas. O conhecimento é posto de forma mais orgânica, as carteiras não ocupam a maior parte das propostas. A brincadeira é valorizada como aspectos de desenvolvimento de pesquisas realizadas pelos estudantes. Assim, o corpo, a expressão infantil, é o grande motor de observação e atenção pela forma como as crianças estão se relacionando com as aprendizagens.

Fazer essa reflexão, no entanto, só é possível, quando professoras e professores se permitem a se questionar, a se investigar como parte inerente do processo escolar. São educadores reflexivos, críticos, que, ao se deparem com as limitações, não paralisam. Pelo contrário, procuram ampliar suas pesquisas, colocando-se como sujeitos ativos de suas formações. Transformam suas práticas ao mesmo tempo em que procuram transformar a si mesmos, como é o exemplo de Letícia:

A palavra é muito confortável para mim, muito, isso é louco. É isso a a escrita: ela atropelou meu desenho lá atrás. Sempre fui boa com as palavras, língua portuguesa era minha matéria preferida. Mas como pode desassociar uma coisa da outra? E é interessante porque eu reconheço que tenho uma escrita poética, não é literatura, mas tenho jogo com as palavras que flui, de um outro jeito que não é essa formalidade. Tenho esse lugar seguro, no código. Se eu tentar colocar em desenho o que estou querendo dizer, não curto e não vai. Não consigo colocar no lápis, no papel, experimento colocar e me sinto muito desconfortável. Tudo isso que eu propus de qual cor você usa pra expressar que você está triste, para mim não funciona. Não vai. É muito louco porque a gente fala que todo mundo sabe desenhar e eu realmente acho que todas as crianças sabem desenhar, mas eu não sei. E eu já fui criança. Deve estar em algum lugar, a criança não atropela isso com racionalidade, mas não deixa de ter uma necessidade de elaboração e aí isso também não é que qualquer coisa vale. (...) Apesar de gostar muito de arte, de sempre levar a arte pra sala de aula, de ser essa linguagem que eu tenho tesão de propor para as crianças, a minha limitação esbarra exatamente na minha falta de formação com Arte. Para mim é isso, adoro estudar um artista, adoro pegar uma referência artística e propor outras coisas. Eu adoro experimentar as possibilidades dentro de um contexto, de um banco que eu seleciono de obras de artista e tal. Eu tenho muita dificuldade de propor uma coisa que vejo as professoras de arte fazendo. Pensando propostas com uma gama de materiais, sabem como combinar possibilidades, sabem montar uma mesa convidativa, elas sabem como juntar este papel com esta cola, o porquê dessa cor, elas sabem que esta conjunção vai possibilitar situações. Isso eu não sei fazer. Tenho muita dificuldade com cantos de artes, eles ficam empobrecidos, ficam repetitivos, desgastam porque eu não sei fazer essas combinações. Mas é isso, a sala de aula precisa disso, o desenho é a constituição da criança durante muito tempo. Por fim, acho que na faculdade a gente aprende tudo racionalmente, você entende a importância de ter um corpo brincando, entende a importância de propor desenhos, lê coisas sobre isso.

Quando entramos nos cursos de formação inicial, levamos nossa história. Se, de fato não nos foi oferecido espaços de vivências e experiências no campo da arte e a possibilidade de ampliação da relação com o nosso corpo e mente, nosso corpo expressará essa narrativa. Como, então, desenvolver essa limitação em nossa formação inicial? A professora entrevistada compreende a importância da arte em suas práticas educativas, busca superar esse desafio, mesmo sem ter tido essa vivência no curso de Pedagogia. Compreende que nossa formação em arte é levada de forma bastante racional, metodológica, e com pouca ênfase nos campos de experiência. Ainda que houvesse tentativas de outras perspectivas formadoras nos cursos, algo acabou se perdendo com a escolaridade. A relação com o corpo é algo fundamental para problematizarmos e há uma política institucional que reflete essa relação. Talvez essa seja uma resposta para pensarmos por que nossa relação com o corpo é totalmente fragmentada.

E também a questão não é: "vamos fazer oficinas", já vivi isso. Não, mas espera aí, tem um destrave desse corpo, porque tem pudores, tenho vergonha, eu estou numa sala com mais de 60 pessoas que eu nunca vi. Não venha falar que então a gente precisa ter esse corpo

brincante e então vamos brincar. Fica distante, fica performático no sentido ruim. Lembro de uma aula na Faculdade de Educação que era: vamos à brinquedoteca. Sei que a intenção é boa, mas experimentar o quê? São 19h30 da noite, um corpo de 20 anos, super reprimido, vai brincar?

Acho que quanto mais repertório, maior a chance. Exatamente por isso, para você é o teatro, é importante porque em algum momento ele foi oferecido. Não me imagino fazendo teatro de jeito nenhum, não é minha linguagem. Ao mesmo tempo, a minha linguagem é artes visuais, só que eu não consigo exercer, mas consigo propor. Não sei explicar o porque que é a arte visual, mas em algum momento ela fo oferecida, me tomou, mexeu com alguma coisa em mim. Quanto mais acesso, maior a chance de você encontrar essa coisa.

Letícia conclui situações fundamentais, se coloca à prova, expõe suas dúvidas e fragilidades ao refletir sobre si como sujeito atuante no mundo. É professora, realiza esse exercício de forma sensível, entregue; constitui-se com seus estudantes, mas também é uma pessoa dotada de desejos tão 
impulsionadores quanto a docência. Reconhece que se aproxima de uma linguagem artística - as artes visuais são a sua linguagem, como ela mesma reconhece - mas tem dificuldade em exercer esse aspecto no campo da experiência. Aponta uma questão de que, talvez, a escrita tenha atropelado seu desenho. Possivelmente, a escola, professoras e professores, mesmo não querendo realizar esse atropelamento, ainda estejam atropelando muitos processos formativos que nos constituem enquanto sujeitos.

Trazer essas vozes pode nos auxiliar a refletir sobre como esses campos de experiência têm atuado, têm se construído e construído nosso devir professora. Nesse mosaico que foi narrado por ela, entendemos o quanto trabalhar de forma integral com as linguagens artísticas desperta nas professoras e em seus estudantes conhecimentos e saberes genuínos. Percepções de si, do outro, nos (trans)formam em corpos criadores e pulsantes por mudanças e expressão. Por outro lado, suas dúvidas e questionamentos, só reforçam a urgência de se pensar que, antes de exigir que professores da Educação Infantil assumam as aulas de artes, precisamos pensar os cursos de formação em arte. No entanto, para além de assumir as aulas de Arte, há algo dessas expressões que nos move a buscar novas formas de construção de nossa subjetividade. Propor vivências e experiências no campo da Arte e trabalhar de forma integral as metodologias de ensino onde o campo da experiência podem tornar-se formas potentes de formação de professoras e professores. Podemos, assim, ampliar a relação com o corpo, corpo esse que vai atuar justamente em uma faixa etária que é corporalmente pulsante e que vai ampliar nossa percepção pelas expressões das infâncias. Sabemos que é uma realidade que se coloca em movimento, essa discussão é antiga e atual. Que o movimento da vida possa fazer emergir novas questões fundantes para se pensar a importância da arte na pedagogia.

\subsection{BIANCA: DAS AULAS DE DANÇA AO ENCONTRO} COM A DOCÊNCIA

Para encontrar Bianca, saí de casa bem cedo em uma manhã de sábado; combinamos de nos encontrar em Santo André. Nunca tinha feito esse percurso. Fui até a estação do Brás e peguei um trem até a estação Prefeito Celso Daniel. No percurso, fui observando a transformação da paisagem. Imaginava que era um caminho habitual em sua vida. Durante quatro anos, Bianca o fizera todos os dias, são muitas horas de deslocamento, de caminho, para chegar à USP. Era, no entanto, uma viagem, um trajeto, para se construir e para se (trans)formar em pedagoga.

Bianca, entre todas, foi a única que seguiu o roteiro tal como foi estruturado. Ao ser interrogada sobre os caminhos que a levaram para o campo da educação, descubro que, primeiro, veio sua relação com a arte, com a dança, para depois seguir sua jornada como pedagoga.

Na verdade, a arte sempre esteve comigo, desde que eu era pequena. Eu comecei a gostar de dançar e quando eu tinha 13 anos, fui com a minha família ao SESC - Santo André, ele havia acabado de inaugurar. Vi que estava tendo aulas abertas de dança afro, durante aquele mês, e comecei a frequentar as aulas. Assim, passei a ir ao Sesc todos os finais de semana, dançando todos os ritmos que iam surgindo. Até que o SESC trouxe o ritmo "zouk" (que é a dança de salão). Aí me identifiquei muito, gostei bastante e comecei a fazer um curso fechado. Depois de um tempo, o professor que dava esse curso me chamou para participar de sua escola de dança como professora auxiliar. Na época, eu tinha uns 15 anos e comecei a trabalhar; depois me tornei monitora e, por fim, professora. Era bem novinha, trabalhei lá até uns 19 anos, acho. Enquanto estava trabalhando na escola de dança, conheci uma aluna que era professora universitária. O professor que me dava aula na escola de dança era bem sonhador, via a dança não apenas como uma mera execução de passos, mas como uma possibilidade de convivência coletiva com o outro, de olhar no olho, de você respeitar os limites e as dificuldades das pessoas. Isso me tocava muito, não era só a dança pela dança, é uma forma de você conhecer pessoas, outra realidades, outras formas de ser, de viver e de sentir. Foi então que a professora universitária fez uma proposta: na época era professora de universidade particular de Pedagogia e se propôs a fazer uma formação com os auxiliares e professores da escola de dança. Tinha a intenção de que a gente pudesse perceber algumas coisas. Foi então que ela trouxe o Paulo Freire. Foi a primeira vez que tive contato com a obra 
dele e com a "Pedagogia da Autonomia." ${ }^{43}$ (...). Fomos discutindo e percebendo algumas questões, aquilo foi fazendo com que eu ficasse cada vez mais envolvida. Isso tudo quando eu tinha 16 e 17 anos, trabalhava como professora e estava finalizando o ensino médio. Daí veio a questão do vestibular, aquele medo de sabe o que eu iria prestar. Estava estampado para mim que eu não poderia ter outra profissão que não professora ou educadora, precisava ter um envolvimento com os problemas e as realidades das outras pessoas (...). Foi aí que busquei a pedagogia. Fiz o processo seletivo para a Faculdade de Educação da USP e passei.

\subsubsection{Foram muitas experiências e vivências que não} posso deixar de reconhecer

Bianca, antes de escolher o curso de graduação, vivencia uma experiência bastante singular que provoca nela uma transformação enorme. Passa a solicitar o corpo de forma integral. Percebe na dança uma forma de construções de saberes e de relações particulares consigo e com o outro. O contato com a obra de Paulo Freire acontece como impulso para se pensar, para se construir e se realizar professora. Chega à universidade contaminada por esses afetos que percorrem suas escolhas, pensamentos, pesquisas e andanças pela educação.

No curso, a princípio, o primeiro ano foi bem difícil, não me identificava com nada daquelas disciplinas que eram oferecidas. Muito teóricas, metodológicas, Filosofia da Educação e História da Educação. Nada daquilo dialogava com aquela arte primeira que eu havia me proposto e o que eu estava procurando. Conforme as disciplinas foram terminando, fui fazendo outras e conheci a professora Patrícia ${ }^{44}$, que é minha orientadora hoje no mestrado. Ela dava disciplina de Educação Infantil. Isso foi no terceiro ano. Fiz a disciplina e fui conversando com ela: disse que eu tinha muito interesse em pesquisar a arte de alguma maneira. Eu já estava concursada como professora auxiliar de primeira infância na prefeitura de São Caetano do Sul. Tinha contato com crianças, estava trabalhando em uma EMEI período integral para as idades de cinco a seis anos. Então, já tinha essa vivência com a infân-

43. O livro "Pedagogia da Autonomia - Saberes necessários a prática educativa", foi a última obra lançada em vida de Paulo Freire. São Paulo, Paz e Terra, em 1996.

44. Patrícia Dias Prado é professora doutora da Faculdade de Educação na USP, no Departamento de Metodologia de Ensino e Educação Comparada, na área da Infância. cia e com educação infantil. É uma área que eu me identifico e gosto tanto, via a possibilidade de tentar levar a arte para a escola. Foi aí que fiz o meu projeto de iniciação científica com minha orientadora. $\mathrm{Na}$ época, pesquisei as narrativas de história e como elas poderiam ser importantes para as crianças; se elas não fossem apenas meramente contadas, simplesmente sem interpretação, sem vontade e sem abertura para o mundo da imaginação. Nessa defesa, eu percebi que as crianças gostavam muito das histórias que eu narrava, havia tido como embasamento os Lab_Artes da USP. ${ }^{45}$ Frequentei por dois anos, primeiro de dança e depois de narrativas de histórias. Isso me trouxe embasamento para que essa arte aflorasse. Além disso, no ano de 2010, fiz a disciplina optativa na grade da pedagogia de "Dança e Teatro". Era uma disciplina em que a gente ficava pouco nas cadeiras e nas carteiras dentro da sala, tínhamos muitas discussões em roda, sentados no chão, descalços, vivências mesmo. Vieram vivências de samba de roda, coco, jongo, fizemos apresentação de ritmos e na época ainda estava na dança de salão. Fiz uma coreografia com as meninas na qual eu me vesti de homem, era o malandro da gafieira, e elas dançavam juntas. Fizemos uma montagem e cada grupo, ao final, escolheu um ritmo ou uma história de dança onde a gente se apresentou e compartilhou com os outros. Foram muitas experiências e vivências que não posso deixar de reconhecer como importantes para a minha formação como professora. Mas isso não basta, sinto que ainda não estou completamente formada e espero que não esteja. Acho que a gente sempre tem que buscar cursos, informações, possibilidades de viver essas experimentações, porque isso é que nos forma. Mas, claro, ouvir as crianças é fundamental. Porque se a gente não olha para as crianças, estaremos sempre impondo nosso ponto de vista, e não o ponto de vista delas.

Há algo fundamental que diz respeito às vivências no campo da arte como potência formativa. Tais vivências passam pelo corpo, pelas expressões para se tornarem conhecimento e possibilidade educativa para si e para os alunos. Bianca compreende a importância das vivências corporais como expressão de conhecimento, de construção de si e da forte relação

45. Conforme o site, "O Lab_Arte é um laboratório didático da FEUSP criado em 2006 por iniciativa dos alunos de Pedagogia para tentar suprir uma importante lacuna nas atividades formativas da instituição, a partir de experimentações e vivências nas várias linguagens artísticas, numa perspectiva antropológica, levando em conta a diversidade cultural, étnica e artística. Oficialmente vinculado ao EDA, foi aprovado como laboratório didático pela Congregação FEUSP, bem como se constitui como diretório de pesquisa no $\mathrm{CNPq}$, agregando professores e investigadores de várias instituições públicas de pesquisa no Brasil e no Exterior, além das atividades de cultura \& extensão de que protagonista." Extraído de: <www.labarte.fe.usp.br>. Último acesso em: 18 abr. 2019. 
que esta linguagem desempenha para estabelecer relações com os outros sujeitos envolvidos no processo. Esse processo a constituiu como educado$\mathrm{ra}$, a faz se questionar, buscar novas possibilidades formativas. No entanto, apesar de ser uma fonte de conhecimento e aprendizagem, entende que isso apenas não basta. Parte, assim, em busca de novas fontes, compreende que o diálogo com seus estudantes é indispensável para se construir um processo educativo não autoritário.

Ao ingressar na universidade, vivencia a experiência no Lab_Arte em algumas disciplinas e, com a pesquisa, estabelece sua relação mais viva. O conhecimento passou pelo corpo, pela relação que estabeleceu com o universo artístico apresentado pelo curso e pelas professoras e professores, assim como pelo desejo de encontrar esse espaço.

Era muito novinha quando entrei na USP, tinha 17 para 18 anos. Moro em São Bernardo, então São Paulo para mim era um universo distante. Ainda é, ainda continuo me aventurando por ela. Eu tinha muito medo, isso é uma coisa que eu até me cobro bastante. Fiz quatro anos de pedagogia e não fiz nenhuma disciplina fora da FEUSP. Tinha medo, a gente escuta boatos de estupro, que a USP à noite é perigosa, que pode ser assaltada. Na época, eu ia de ônibus e por isso eu tinha medo de sair do prédio. As minhas vivências se restringiram aos Lab_Arte, que acontecem no prédio, e a essas disciplinas que envolviam a arte de certa forma. Quando comecei a fazer a iniciação científica, pude também pesquisar mais coisas na biblioteca, conhecer outras pessoas, ter acesso a outros professores. Como, por exemplo, a professora Monica Caldas. Fiz uma disciplina com ela que me ajudou muito nessa questão do corpo. O professor Marcos Neira me ajudou muito a refletir, era uma disciplina de Metodologia de Educação

Física. Não é propriamente o que eu pesquiso, o que eu acredito para a Educação Infantil, mas tem coisas que estão atreladas e que me ajudam a pensar o meu corpo, o corpo das crianças, como esses corpos têm que estar ou como eles podem estar nos espaços educativos para além das carteiras e cadeiras, que é o que a gente encontra inclusive na educação infantil.

2.5.3. Se a gente não sente aquilo na pele,

não tem como passar essa experiência, a gente

não tem como proporcioná-la às crianças

As experiências acumuladas aos anos de docência e de dança e as vivências estudantis, atreladas ao seu trabalho como professora na rede municipal de ensino, são suas bases de indagação, reflexão e pesquisa para atuar de forma criadora em suas práticas educativas. Estabelece parcerias com suas colegas de grupo de pesquisa e extrai conhecimento para se (trans)formar.

Compreende algo fundamental e que vem sendo refletido ao longo dessa escrita: para que nós, pedagogas e pedagogos, possamos dialogar com os campos de experiência em arte, precisamos, necessariamente, experimentar fazer, vivenciar e incorporar a nossa formação, práticas em arte. Pois se essa experiência não passa pelo nosso corpo, por nossa pele - operando na realização dessas expressões - nosso trabalho fica limitado.

Gostaria de falar sobre o trabalho de duas parceiras do grupo de pesquisa. Elas pesquisaram a disciplina de Dança e Teatro, essa disciplina que mencionei. Fizeram uma formação com a disciplina e depois cada uma escreveu um artigo. ${ }^{46}$ Eles falam sobre a necessidade de o professor ter acesso à arte e sabemos muito bem que não são todos que têm esse interesse ou a oportunidade de ter o contato com a arte, seja ela em qualquer uma de suas formas. Uma das coisas que as duas desenvolvem nos artigos é a importância das professoras e professore viverem a arte, porque se a gente não sente aquilo na pele, não tem como passar essa experiência, a gente não tem como proporcioná-la às crianças. Não tem como refletir sobre ela. Sendo assim, só quem vive pode proporcionar; se você não vive, você não consegue fazer isso, vai tirar de onde? Os alunos da graduação que frequentaram a disciplina, ao final, comentam a importância dessa vivência, refletem sobre o que movimentar o corpo teve naquele momento. Coisas que eles nunca haviam pensado, nunca haviam vivido, mas que, de repente, dali para frente poderiam repetir para a sala de aula.

Para se trabalhar em sala de aula as linguagens artísticas, é fundamental que pedagogas e pedagogos possam também experienciar tais linguagens; é aprendendo a fazer, a realizar, a refletir, a se questionar, a conhecer e desenvolver-se, que somos capazes de enfim ensinar, de trocar essas experiências com nossas alunas e alunos. Transformar o campo da Arte em saber na escola passa por vivenciar este saber no corpo e na mente de quem atua na escola. Dialogando de maneira interdisciplinar com as áreas do conhecimento, é saber apreender a importância de sua integração. Isso é uma questão que reflete determinadamente o processo de formação de professoras e professores. Além disso, o campo da Arte é um campo de metodologias e abordagens, e elas também são capazes de

46. Os artigos mencionados encontram-se em: PRADO, Patrícia Dias e SOUZA, Cibele Witcel. Educação Infantil, diversidade e arte. Organizado pelas professoras. Editora Laços, 2017 
construir campos de experiência, uma vez que são modos de estruturar o conhecimento no mundo.

Sair à deriva e construir uma prática docente que se realiza nos campos da experiência é saber indagar seus atos, é compartilhar as dúvidas, as dificuldades que essa caminhada vai gerar. É lidar com a incompletude. Assim, Bianca se lança, se refaz, se mostra curiosa e desejante pelo conhecimento.

Quando a gente começa a dar aulas, damos muita cabeçada. Por mais que você já tenha vivido experiências, as demandas das escolas, impondo coisas, materiais, são enormes, e a gente acaba se perdendo. Vivi muitas vezes, no início da carreira de professora - já estou há nove anos como professora de educação infantil - um pouco perdida, fazendo coisas nas quais eu não acredito, ou coisas que vão na contramão daquilo que eu pesquiso. Mas, com o tempo, a gente vai aprendendo a lidar com essas coisas.

Essa questão apresentada por Bianca mostra o quanto seu trabalho é fundamental e que professoras e professores possam encontrar espaços para refletir suas práticas educativas. Saber se repensar, se questionar, para que assim possamos avançar em nossas dúvidas e pesquisas referentes à docência. Aqui se coloca fundamentalmente a importância da professora pesquisadora que, ao se deparar com seus erros, não se paralisa; pelo contrário, busca novos horizontes.

2.5.4. Essa coisa de propor só com pé, uma vez que eu poderia ter proposto com corpo inteiro

(...) Vou citar alguns exemplos de coisas que eu fiz com as crianças: ano passado, por exemplo, percebi que a temática do corpo estava muito em evidência; estava trabalhando com crianças de 4 a 5 ano nas prefeituras de São Bernardo e Santo André. Comecei a fazer inúmeras intervenções com as crianças. Por exemplo, em uma das escolas tem um esqueleto, levei o esqueleto para dentro da sala de aula e pesquisamos sobre os nomes dos ossos. Vimos onde eles ficavam, as crianças tocaram o esqueleto, observamos a partir do crânio, fizemos atividades de escrita relacionada a isso. Tinha um contexto. As crianças estavam interessadas, fizemos propostas de desenhos para que elas pudessem desenhar o esqueleto; para que eles desenhassem, a gente foi fazendo movimento como, por exemplo, cambalhota. Fui ensinando-os a virar cambalhota de costas porque só sabiam fazer isso de frente. Fazemos rodas de conversa com as crianças para ouvi-las. Elas vão pensando em outras ideias, outras propostas, e muitas coisas vão surgindo daí. Na escola de Santo André, tem a questão da brincadeira simbólica, que é um termo que eu problematizo, porque se é brincadeira, é simbólica. Por que é que nós adultos temos que dizer que é simbólica? É uma dificuldade nossa de não conseguir enxergar a brincadeira como simbólica e as crianças já identificam (...). Outro exemplo que eu gosto muito de fazer são as melecas. Já fiz meleca com os pés, misturo o pé com a água, com barro, com tinta, texturas. Essa coisa de propor só com pé, uma vez que eu poderia ter proposto com corpo inteiro, mostra um pouco da minha limitação e da não limitação das crianças, que veem o corpo como uma coisa só. Na educação infantil é tudo junto, não há fragmentação das aulas. Acho que esses, inclusive, são até alguns erros que a gente comete quando entra. No começo até colocava as plaquinhas da rotina, do que ia se fazer no dia: hoje é dia de português, depois matemática. Hoje eu já não uso mais, coloco as plaquinhas com as atividades, não importa se é matemática ou arte, porque elas estão sempre imbricadas, você nunca trabalha um campo só da experiência sozinho (...). Também levo obras de arte, de artistas diferentes, contemporâneos ou não, para a gente discutir um pouco essa questão. A questão da figura humana é algo que a gente sempre discute muito. Gosto muito de trabalhar com o artista Ivan

Cruz, ele não pinta rostos e isso é sempre um enigma para as crianças. Porque ele não pinta? E aí eles dão várias sugestões: "ah, é porque ele esqueceu; "ah, é porque ele não sabia fazer"; "a prô dele não ensinou"; "ah, eles estão de costas e por isso que não tá dando pra ver o rosto". São muitas ideias, a gente vai trabalhando nessa perspectiva a cada ano. Em decorrência dos projetos, dos interesses das crianças, ano passado minha temática foi o corpo.

Bianca vai costurando uma teia de saberes em sua narrativa. Como professora da Educação Infantil, procura integrar as aulas e não separando as disciplinas. Para ela, atualmente, não cabe mais segmentar os campos dos saberes e, sim, promover situações onde todas as linguagens são pensadas de forma integrada. Navega de outra forma, se percebe em movimento e em transformação.

No entanto, uma singularidade de sua experiência é a percepção da importância de se pensar o corpo e a mente de forma integrada. As demais entrevistadas haviam indagado sobre essas questões do corpo e de como vamos tolhendo e cerceando o corpo das crianças em carteiras, cerceando seus movimentos e não os reconhecendo como fonte de saber - que também aprende, que também conta história. As crianças se expressam pelo corpo, são expressivas, realizam inúmeras possibilidades ao mesmo tempo. Os processos de aprendizagem em arte partem do corpo brincante e os desenhos contam histórias. As relações entre o simbólico e o real são orgânicas e desassociadas. 
Nesse aspecto, encontro muita semelhança entre as narrativas produzidas pelas minhas parceiras pedagogas. Por mais que cada uma tenha uma vivência, uma experiência bastante singular em relação ao campo da arte/ educação, todas vivem uma prática educativa totalmente dialógica com seus estudantes. Compreendem o que Paulo Freire nos ensinou sobre a importância de sermos capazes de estabelecer diálogo com nossas alunas e alunos, percebendo a educação como um campo de troca de saberes. Se aprendemos a ouvir, aprendemos que nossos alunos são criadores de saberes, de cultura. Aprendemos e ensinamos em uma relação dual e total.

\section{DAS SINGULARIDADES PARA OS ENCONTROS DE UMA PRÁTICA} EDUCATIVA MERGULHADA NA ARTE/EDUCAÇÃO

Após evidenciar as singularidades dos campos da experiência em Arte e como ela chega à sala de aula das quatro pedagogas entrevistadas, me proponho a costurar as linhas de encontro, de imbricamento, de cruzamento da caminhada pela arte e pela educação. Apesar das singularidades, encontramos muitos pontos que nos fazem refletir sobre a importância de se criar uma prática a partir de uma relação viva, respeitosa, de troca e de mergulho na educação com nossos estudantes.

O mais importante desse processo foi perceber o quão rico é pensar a diversidade do que foi apresentado pelas colegas. Como anunciei na introdução deste capítulo, não se trata aqui de enquadrar cada uma em uma caixinha do que é certo ou errado. Apesar de termos uma formação comum, na mesma universidade, a construção de nossas práticas, buscas e (trans)formações no âmbito da educação, passa também por questões atreladas a nossas histórias e desejos. O meio social, o familiar, o escolar e a universidade foram constituindo cada uma de nós a nossa maneira.

Todas as entrevistadas me forneceram matéria bruta e substância para que eu pudesse compreender o coração da minha pesquisa: como as experiências de vida e formação em arte contribuem para que pedagogas e pedagogos dialoguem, em suas práticas em sala de aula, com o campo da arte/educação?

Ainda que cada pessoa envolvida nesta escrita tenha construído histórias à sua maneira, encontramos a inquietude como força motriz de nossa característica viajante. Nos criamos na curiosidade, nossa e de nossos estudantes, e seguimos uma jornada na qual, em muitos momentos, não conseguimos ver a chegada. O resultado, na verdade, não importa. O que nos move é justamente o processo, é a partir dele que nos realizamos e extraímos a substância necessária para nossa (trans)formação.

Carolina busca em sua essência a relação orgânica que, desde sempre, vivenciou de forma bastante genuína com as linguagens artísticas, e esse é seu ponto de apoio para levar o campo da arte/educação para suas práticas. Dessa vivência, constrói seus percursos, extrai suas dúvidas e inquietações para proporcionar às suas alunas e a seus alunos a importância de viver na escola práticas educativas que dialogam com a arte.

Priscila, ao mergulhar profundamente nas infâncias, as concebe enquanto produtoras e transformadoras de cultura, observando nos gestos e expressões sua fonte de pesquisa. Ao respeitar suas criações e ao compreender a característica brincante e artística das crianças, é capaz de desenvolver, em sala de aula, situações de aprendizagens onde arte e os demais conteúdos possam caminhar de mãos dadas. Esse gesto a faz trilhar uma busca que permeia indagações, olhares e muita atenção, tanto pela 
maneira como as crianças estão se relacionando com o conhecimento, quanto pela forma como expressam suas pesquisas criadoras.

Letícia encontra na escola e na sala de aula a escuta mais atenta e perspicaz para encontrar um caminho para que a arte possa ocupar um lugar de igualdade com os demais conteúdos a serem trabalhados. Observa nas crianças como as suas próprias limitações foram se desenvolvendo e, assim, busca um exercício de alteridade e confiança para que suas alunas e alunos possam se expressar de uma maneira mais aberta, livre, e se construir de outra maneira. Possibilita situações de aprendizagem para que os estudantes possam se relacionar com seus corpos, como desenhos, imaginações e expressões de forma mais orgânica e consciente.

Bianca, que antes de ser professora das infâncias foi professora de dança, encontra no corpo um elemento potente para expandir a aprendizagem de suas alunas e alunos. Provoca em sala de aula uma série de propostas que quebram fronteiras das disciplinas, fazendo da Arte, da Língua Portuguesa, da Matemática e das demais áreas do conhecimento, um universo único e particular. Se questiona, se pergunta e busca em sua prática uma fonte viva de suas pesquisas.

Um ponto de encontro fundamental que compreendo existir entre nós cinco é a relação do olhar que estabelecemos com as crianças. Encontro, assim, um fio condutor. $O$ reconhecimento de seus saberes, suas singularidades, suas pulsões criadoras, seus devires, nos impulsiona a cultivar mutuamente esses aspectos. Aqui, encontramos uma ressonância enorme do pensamento de Paulo Freire (2016, p. 25):

Ensinar inexiste sem aprender e vice-versa, e foi aprendendo socialmente que, historicamente, mulheres e homens descobriram que era possível ensinar. Foi assim, socialmente aprendendo, que ao longo dos tempos mulheres e homens perceberam que era possivel - depois, preciso - trabalhar maneiras, caminhos, métodos de ensinar. Aprender preciso - trabalharmaniras, caminos, métodos de ensinar. Aprender precedeu ensinar ou, em outras palavras, ensinar se diluía na experiência realmente fundante de aprender. Năo temo dizer que inexiste validade no ensino de que não resulta um aprendizado em que o aprendiz não se tornou capaz de recriar ou de refazer o ensinado, em que o ensinado que não foi apreendido não pode ser realmente aprendido pelo aprendiz.

Assim, ensinando e aprendendo, construímos novas formas de olhar para a educação, nos transformamos. Nossos caminhos pelo campo da educação passam por lugares onde provocamos questionamentos que nos impulsionam a construir outros modos, outros lugares e saberes. Tais processos só são realizáveis por encontrarmos em nossas alunas e alunos uma relação de potência, de troca, de aprendizado, como afirma Paulo Freire. Nos construímos no outro, com o outro e pelo outro.

Ao adentrarmos na relação com o universo infantil, acionamos nossa memória, criamos nossa linha de edição e, com ela, solicitamos o corpo e a mente. Incorporamos a experiência, somos tomadas e nos enxergamos em nossas alunas e alunos. É recorrente pensar as práticas educativas a partir do que fomos, dos pontos onde encontramos nossos desafios, nossos limites, mas, também, nossas potências. Atuar e reconhecer, no campo da experiência, uma importante fonte de saber, nos ajuda a realizar uma prática docente comunicativa, expressiva e, portanto, criadora. Assim nos diz Bell Hooks (2017, p. 144):

(...) Essa estratégia pedagógica se baseia no pressuposto de que todos nós levamos à sala de aula um conhecimento que vem da experiência e de que esse conhecimento pode, de fato, melhorar nossa experiência de aprendizado. Se a experiência for apresentada em sala de aula, desde o início, como um modo de conhecer que coexiste de maneira não hierárquica com outros modos de conhecer, será menor a possibilidaño de ela ser usada para silenciar.

Na contramão de se pensar uma prática educativa pelo silêncio, escutamos nossos estudantes, os observamos. Falantes, eles nos contam suas histórias, seus desejos, e expressam suas relações com o conhecimento. Nos ensinam o quanto a caminhada em uma perspectiva integral com as práticas artísticas torna-se uma importante ferramenta para dissolver barreiras no ensino. Nos ensinam que a hierarquia entre os campos dos saberes não existe. Criam e recriam a si mesmos. Atentas a isso, nos recriamos com eles.

O campo da experiência diz respeito aos acontecimentos advindos de nossas práticas e nos gerou alguma transformação. Mesmo que tenhamos vivido situações difíceis, nos fez abrir caminho para mudarmos a rota. Essa relação só é plausível quando adentramos no campo da educação mergulhadas em incertezas, nos fazendo pensar e repensar de que modo estamos estabelecendo nossas práticas, assumindo nossos erros, criando dúvidas e possibilidades. Incorporamos a arte como força motriz desses acontecimentos, procuramos não desassociar uma coisa da outra e, assim, fazer dessa experiência uma fonte de saber. Isso nos aproxima a Larrosa (2013 p. 13) quando o autor escreve que:

Há algo que fazemos e no que nos acontece, tanto nas artes como na educação, que não sabemos muito bem o que é, mas que é algo sobre o que temos vontade de pensar, e de continuar pensando, é algo a partir do que temos vontade de cantar, e de continuar cantando, porque justamente isso é o que faz com que a educação seja educação, com que arte seja arte e, certamente, com que a vida esteja viva, ou seja, aberta a sua própria abertura. Assim insistirei, para terminar, que não se pode pedagogizar nem didatizar, nem programar, nem produzir a experiência; que a experiência não pode fundamentar nenhuma técnica, nenhuma prática, nenhuma metodologia; que a experiência é algo que pertence aos próprios fundamentos da vida, quando a vida treme, ou se quebra, ou desfalece; e em que a experiência, que não sabemos 0 que é, às vezes canta. 
Se compreendemos que a experiência em arte e educação parte de uma fatia fundamental que nos ajuda a fundamentar nossa vida - nos faz existir, nos faz abrir brechas para o desconhecido, nos faz criar devires, de ser o outro e também cantar - possibilitamos a nós mesmos rotas de fuga. Precisamos viver o campo da arte, não apenas para transportá-la para nossas práticas pedagógicas mas, também, para nos construirmos enquanto sujeitos, para nos criarmos enquanto seres atuantes e desejantes de uma vida pulsante. Tudo isso nos causa inquietude e este é um aspecto, embora singular, bastante comum nesta narrativa.

Reviver as memórias, refletir sobre a experiência, é reconhecer uma amplitude de possibilidades frente à vida, é buscar outra situação.
Voaremos sobre as ruinas

\& teatro mossas

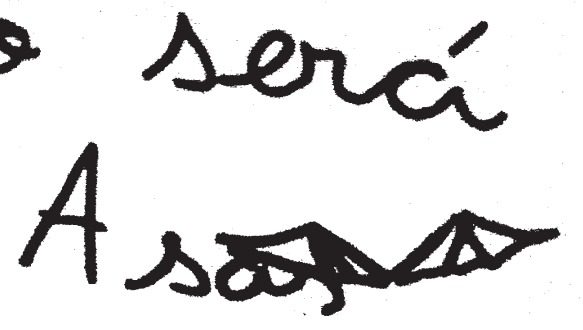


EPÍLOGO CONCLUSÃO 
Os professores que amam os alunos e são amados por eles ainda são suspeitos na academia. Parte desta susde paixões, pode impedir a consideraça objetiva dos mérixos méritos de cada aluno. Mas essa noção se baseia no pressuposto falso de que a educação é neutra, de que existe um terreno emocional "plano" no qual podemos nos situar para tratar a todos de maneira igualmente desapaixonada. (HOOKS, 2017. p. 262)

Chego ao desfecho desta longa viagem, ainda que temporário. Para ele, estabeleço diálogo com o que Bell Hooks nomeou Eros, erotismo e o processo pedagógico. ${ }^{47} \mathrm{~A}$ autora reflete sobre as paixões, o amor e a figura de Eros nas relações estabelecidas nos contextos educativos. Não se trata de uma perspectiva meramente erótica. Ela nos apresenta a educação como uma fonte movente da potência humana, força vital, elemento formador que essa viagem me trouxe a respeito da experiência de existir como professora.

As escolas e as universidades são lugares que promovem, por excelência, encontros humanos. Os encontros podem trazer uma natureza bastante sensível, profunda e, quando possível, transgressora dessa ordem tão embrutecida. Quando o ensino se realiza dentro dessa perspectiva, a sensibilidade, o afeto e a comunhão, como nos ensinou Paulo Freire, nos levam às práticas educativas onde sentimentos transformadores eclodem, sendo capazes de transcender o conhecimento. Conhecimento que, assim, se faz pulsante, forte e potente.

Todo o material cartografado me deu suporte para encontrar um lugar de pausa e perceber o quanto a educação, quando em correspondência ao campo da arte, se realiza pelo diálogo e pela comunhão dos saberes entre os sujeitos envolvidos nesse processo. Assim, estabelecemos com nossos estudantes a percepção e a importância da comunicação atenta no desenvolvimento de uma prática educativa, crítica, ativa e também afetiva. Aqui desenvolvi um elogio à sala de aula e a arte.

Foi sobretudo pelo diálogo que realizei com as entrevistadas que essa percepção se concretizou. Cada uma, à sua maneira singular, com base nas experiências que acumularam ao longo de suas vidas, me deu um suporte capaz de transformar as indagações desta pesquisa de forma mais humana e cuidadosa. Conheci seus percursos formativos e os processos que vivenciam em sala de aula e isto me trouxe outra concepção a respeito das práticas educativas inseridas no campo da arte/educação. Há inúmeras possibilidades de realizar uma situação de ensino onde as linguagens artísticas estejam 
presentes. No entanto, com as contribuições das colegas, somadas à minha experiência, percebo que essa prática ganha amplitude de potência quando estamos inseridas no processo de forma aberta. Quando somos capazes de estar inteiras na relação com nossas alunas e alunos, ouvindo, extraindo de suas proposições fontes de pesquisa e comunicação. A arte nos conduz à essa abertura, não se trata das pedagogas e pedagogos tornarem-se professores de Arte, ou mesmo terem a obrigação de serem artistas, não. O que buscamos é justamente criar uma possibilidade, um diálogo com as linguagens artísticas em nós mesmos, para sermos capazes de promover uma prática educativa mais aberta ao imprevisto, mais disponível à escuta e ao diálogo com nossos estudantes, rompendo fronteiras e abrindo novas possibilidades de se pensar a nossa formação.

A escola e a sala de aula constroem relações formativas, são material humano. Tais espaços podem ser capazes de gerar uma fonte inesgotável de questionamento - de buscas, pesquisas e transformações - quando professoras e professores estão em uma relação viva com a escola e os estudantes, apaixonadas por suas práticas e desejantes, ainda que encontrando inúmeros desafios e existindo em um país que tanto desvaloriza nossa profissão.

É evidente que essa não é uma tarefa tão fácil e certeira, sobretudo em tempos atuais. No entanto, ela é possível e urgente. A maneira como as entrevistadas desenvolvem suas práticas educativas e a relação extensa com o campo da arte, ainda que tenham vivenciado poucas experiências de formação nesse campo, mostra-me uma fonte de desejo. Inevitavelmente, emergem novas possibilidades de se pensar a formação no curso de $\mathrm{Pe}-$ dagogia e a força motriz que é a sala de aula.

O diálogo entre arte e pedagogia mostra-se pungente quando atravessado por relações afetivas, sensíveis e apaixonadas, como defendido por Hooks. Atentas, estabelecemos com nossas crianças uma cumplicidade. Elas, por sua vez, se constroem pelas expressões, criações e sensibilidades na relação com os campos de conhecimento. Aprendem a construir saberes, brincando, narrando histórias, realizando desenhos, dançando e teatralizando situações do cotidiano; perguntando, mostrando outro caminho, transgredindo o que está posto. Com elas, aprendemos também outras vias. Às vezes, até podemos brincar, resignificar nossas práticas e vislumbrar novas buscas pela educação.

Esta escrita suscita-me a importância da relação integral que as crianças estabelecem com seus corpos e mentes e que, ao longo do processo escolar, acaba perdendo amplitude. Assim, vamos crescendo e vamos nos formando. A criança que antes era artista-arteira torna-se, muitas vezes, um adulto sem essas características. Quando somos professoras apaixonadas, questionadoras e pulsantes por uma educação crítica, percebemos que algo foi atropelado, como disse Letícia ao refletir sobre sua relação com o desenho. Algo que na infância era tão habitual, tão orgânico, e que infelizmente vamos tolhendo com a vida adulta.
Indagando sobre esses acontecimentos, somos mais capazes de percebermos a nós mesmos e aos limites que se fazem presentes na vida em movimento, sempre mudando as rotas e itinerários para construir novos horizontes. Essa substância materializa o quanto nossa figura é fundamental para o processo educativo. Somos professoras capazes de associar nosso processo de aprendizagem ao de nossos estudantes. Queremos fazer da sala de aula um lugar onde o aprendizado possa ser tanto desafiador quanto prazeroso. Tentamos navegar por essas águas que podem parecer dicotômicas mas que, na verdade, são a somatória de um processo escolar vivo. Se construído de uma maneira sensível, os desafios e as questões latentes que precisam ser superadas caminham, esbarram, mas não paralisam.

Encontrei modos de se criar outras possibilidades nas experiências que minhas colegas vivenciam. No entanto, fora da rota, encontro a importância dessas experiências para além das práticas educativas. Encontro na palavra experiência um lugar que marca, que deixa resquícios, forma e transforma a vida de quem a vivencia - sendo incapaz, inclusive, de dissociar arte e vida. São caminhos constituidores e fundantes de uma jornada pela construção de sujeitos. O devir professora, buscando transformações para si e para o mundo ao redor e criando possibilidades de um novo caminho para se pensar a educação, a arte e a vida dos que se lançam ao mar, à caminhada, às errâncias e às aventuras de uma existência mais possível. Compreendo a Arte/Educação como uma prática fundamental para sobreviver em nosso tempo.

Estamos vivenciando um período bastante conturbado no Brasil. Inúmeros ataques à subjetividade estão acontecendo, há um projeto político sustentado pelo medo e uma das classes mais perseguidas pelo atual governo federal é a das professoras e professores. Suas últimas medidas têm sido o incentivo à patrulha e denúncia contra os que atuam de forma crítica. O Projeto Escola Sem Partido, ${ }^{48}$ defendido por apoiadores do atual presidente, quer assassinar a escola plural, heterogênea e crítica. Acusando nossa classe de doutrinários, defendem uma reforma do Ensino Médio em

48. Projeto Escola Sem Partido foi criado em 2004. Transformado em associação no ano de 2015, é coordenado pelo Procurador Geral do estado de São Paulo Miguel Nagib. Em 2015, o deputado Izalci Lucas Ferreira, filiado ao PSDB (Partido da Social Democracia Brasileira), apresentou na câmara dos deputados o projeto de lei que inclui entre as diretrizes e bases da educação nacional o "Programa Escola Sem Partido". Tal projeto está na pasta e graças a uma série de pressões ainda não foi aprovado. O site denominado escolasempartido.org. nos diz que: "Se a lei for aprovada pelo Parlamento brasileiro, a doutrinação política e ideológica em sala de aula e a usurpação do direito dos pais a que seus filhos recebam a educação moral que esteja de acordo com suas próprias convicções estarão com os dias contados." Extraído de: <http://www.escolasempartido. org/o-papel-do-governo-categoria/539-dia-historico-projeto-de-lei-que-institui-o-programa-scola-sem-partido-e apresentado-na-camara-dos-deputados ?. Ulltimo acesso em: 29 maio 2019 
O MEC (Ministério da Educação), tendo como atual ministro Abraham Weintraub, pretende operar contra os corpos pensantes e anuncia cortes de verbas nas Universidades e Institutos Federais, além de incentivar denúncias contra professoras, professores, alunas, alunos e familiares que se posicionam a favor de uma educação crítica. A educação em nosso país está sofrendo uma grave ameaça. Sendo assim, esta pesquisa também abordou um diálogo com o momento histórico. Se estou refletindo a importância da arte na escola, na formação inicial do curso de Pedagogia, estou também afirmando a importância da escola, da universidade, das instituições de ensino e do conhecimento em nossa vida. É contra o próprio conhecimento que o governo atual opera.

Na contracorrente desses abusos, no dia 15/5/2019, ocorreu em mais de cento e setenta cidades brasileiras a primeira grande manifestação contra o governo do presidente Jair Bolsonaro..$^{49}$ Foi um enorme ato pela defesa da educação brasileira. Em um artigo publicado pelo jornal Folha de São Paulo, no dia 17/5/2019, o professor e filósofo Vladimir Safatle nos diz que:

De toda forma, o jogo enfim começou. As manifestações não terminaram na quarta-feira. Elas apenas começaram, e com força. Quem esteve nas ruas entendeu que não há negociação alguma com este governo, que o sr. Bolsonaro não age como presidente (...).

O destino do Brasil era passar por uma polarização radical. Isso estava explícito desde as eleições de 2014. Um polo só havia se configurado. Agora, virá o segundo.

Estamos, portanto, diante desse cenário, nos colocando em movimento nesses polos em conflito, e minha pesquisa se desenvolve nesse contexto. Ela se faz como um ato político. Procuro, então, encontrar o que está esquecido, gestos, memórias e formas onde o pensamento e o corpo possam existir em uma unidade indissolúvel, tão rara em nosso tempo, refletindo a arte como conhecimento essencial. Nossa época está marcada por sombras, tempos escassos - como anunciou o poeta Vladimir Maiakóviski, desde o início do século passado. Georges Didi-Huberman, ao introduzir o livro Levantes, nos pergunta sobre nosso tempo: Tempos sombrios: o que fazer quando reina a obscuridade? (DIDI-HUBERMAN, 2017 p. 14).

49. Jair Messias Bolsonaro foi eleito presidente do Brasil, em 2018. Sua campanha foi marcada pelo um discurso de ódio, pelas falsas informações e pela defesa do armamento da população. Discursava claramente contra a população negra, os povos originários de nossa terra, a população LGBTQ (lésbicas, gays, bissexuais, transexuais e queers) as mulheres. Além de explicitar veementemente o desprezo pela classe de professoras
O autor escreve:

Os "tempos sombrios" só são sombrios por baterem na nossa cara comprimirem nossas pálpebras, ofuscarem nosso olhar. Como fronteiras que se impõem em nosso próprio corpo e pensamento. (p. 15, 2017)

As sombras, então, batem em nossa janela, nos mostrando presentes e corporificadas na contemporaneidade; sombras de uma sociedade em guerra, dividida e fragmentada. Procurei, neste trabalho, um outro lugar uma outra visão diante da sombra. Pois se há sombra, há também a luz e a vejo, mesmo que timidamente, batendo em meio à escuridão. Ela não me mostra um caminho assertivo, mas, sim, um outro espaço, um novo cenário transformador e capaz de reacender esperanças. Portanto, mãos à obra, primeiramente na tentativa de transformar a vida para que, assim, possamos cantá-la em consonância com os versos de Maiakóviski.

Procuro novas perspectivas e encontrei nesta escrita um problema, uma reflexão e um sopro que possam contribuir em meio a tantas possibilidades. Entendi que a tarefa da pesquisa não está para além da vida e do tempo, mas, sim, inserida, marcada no mesmo. Aqui, não há outro caminho a não ser o desejo por possibilidades de luz.

Ora, se querem retirar a educação, o conhecimento plural, os corpos em luta, a arte e a poesia de nossas vidas, nos levantamos e dizemos: não! Se querem destruir nossos sonhos e a cultura, dizemos ainda que: nãol Neste sentido, Didi-Huberman acena um caminho para essa jornada:

Mas são imensas ainda as possibilidades, assim como o levante é um gesto sem fim, incessantemente retomado, soberano como pode ser chamado soberano o próprio desejo ou essa pulsão, esse impulso de liberdade" (Freiheitsdrang) que falou Sigmund Freud. O campo do levantes é potencialmente infinito. (p. 17, 2017)

Buscando essa potência infinita, criei um diálogo com nosso tempo, com as marcas deixadas. Num pequeno recorte em meio a tantos desejos, resgatei memórias que puderam me ajudar a reacender uma luz. A educação é um elemento constitutivo da nossa vida, é um elo indissociável para a busca de possibilidades construtoras de conhecimento, cultura e ações frente ao tempo. A arte é a pulsão pela criação de ações que transcendem o verbo. São caminhos de possibilidades, campos indissociáveis, indivisíveis e que, aqui, procurei colocá-los em cruzamento e em trânsito. São ruas que atravessam e nos mostram uma outra via possível.

Por hora, aporto meu barco, depois dessa longa jornada. Naveguei por mares incertos, construí e desconstruí mapas. Eles me levaram para ondas fortes e calmas. Agora encontro um pouso, um lugar para ancorar, embora desejante por novas rotas, novos pontos de partida e novas viagens. As questões, ainda que tenham me ajudado a compreender como as práticas 
educativas em arte dialogam com a sala de aula e também com buscas singulares de pedagogas e pedagogos, trouxeram-me novas questões. $\bigcirc$ tempo abre novas fendas, novos lugares para que eu possa habitar, ocupar e ampliar o debate entre arte e pedagogia. No entanto, as marcas deixadas impulsionam-me para que em breve novos itinerários se façam possíveis. 


\section{REFERÊNCIAS BIBLIOGRÁFICAS}

ANDRADE, Carlos Drummond de. A educação do ser poético. Jornal do Brasil, Rio de Janeiro, 20 jul. 1974.

ANDRADE, Mario. Táxi: da criança-prodígio - I. In: Táxi e Crônicas no diário nacional. São Paulo: Duas cidades, Secretaria da Cultura, Ciência e Tecnologia, 1973.

ARTAUD, Antonin. O Teatro e seu duplo. São Paulo, Martins Fontes, 2006.

BENJAMIN, Walter. A vida dos Estudantes. In: Reflexões sobre a criança, o brinquedo e a brincadeira. São Paulo: Editora 34, 2002.

- Livros Infantis velhos e esquecidos. In: Reflexões sobre a criança, o brinquedo e a brincadeira. São Paulo: Editora 34, 2011.

BOSI, Ecléa. A Substância Social da Memória. In: O Tempo vivo da memória: ensaios da psicologia social. São Paulo: Ateliê Editorial, 2013.

BRITO, Priscila Fernanda. Foi respeitada a expressão da criança quando disse o que fez? - Artes nos parques infantis através das fotografias de Benedito Junqueira Duarte. (Mestrado em Sociologia da Educação). Universidade de São Paulo, FEUSP, 2016.

CAMPOS, Augusto, CAMPOS, Haroldo e SCHNAIDERMAN, Boris. MAIAKÓVSKI. São Paulo: Editora Perspectiva, 2006.

CAMPOS, Augusto. Pagu: Vida-Obra. São Paulo: Companhia das Letras, 2014.

CHARLES, Schwall. O ambiente e os materiais do ateliê. In: O Papel do ateliê na Educação Infantil: A inspiração de Reggio Emilia. Porto Alegre: Editora Penso, 2012.

DELEUZE, Gilles. O que as crianças falam. In: Crítica e Clínica. São Paulo: Editora 34, 2011.

DELEUZE, Gilles e GUATARRI, Félix. Devir-Intenso, Devir-Animal, Devir-Imperceptível. In: Mil Platôs. Vol 4. São Paulo: Editora 34. 2012.

DERDYK, Edith. Formas de pensar o desenho: desenvolvimento do grafismo infantil. São Paulo: Zouk, 2010.

DIDI-HUBERMAN, Georges. Levantes. São Paulo: Edições SESC-São Paulo, 2017.

FREIRE, Paulo. Pedagogia da Autonomia: saberes necessários à prática educativa. Rio de Janeiro: Paz e Terra, 2016.

. Pedagogia do Oprimido. Rio de Janeiro: Paz e Terra, 2016.

FOUCAULT, Michel apud MATTAR, Sumaya, 2018, p. 260. Ética, sexualidade, política: Ditos \& escritos VI. Rio de Janeiro: Forense Universitária, 2004.

GINSBER, Allen. O Uivo. Kaddish e outros poemas. Editora: L\&PM. São Paulo, 1984.

HOOKS, Bell. Ensinando a Transgredir: a educação como prática de liberdade. 
São Paulo: WMF Martins Fontes, 2017

JOSSO, Marie-Christine. Experiência de vida e formação. São Paulo: Cortez, 2004.

LARROSA, Jorge. Pedagogia Profana: Danças, piruetas e mascaradas. Belo Horizonte: Editora Autêntica, 2013.

Tremores: escritos sobre experiência. Belo Horizonte: Autêntica Editora, 2018.

LOPES, Débora OesIner. A inquietude busca da cenografia: a experiência didática de Helio Eichbauer nos anos 1970. Dissertação (Mestrado em Artes Cênicas) - Centro de Letras e Artes da Universidade Federal do Estado do Rio de Janeiro. CLA, 2015.

MAIAKÓVSKI, Vladimir. O Percevejo. Editora, 34, 2009.

MATTAR, Sumaya. Aprender a ouvir o som das águas: o projeto poético-pedagógico do professor de arte. Dissertação (Mestrado em Artes Visuais) - Faculdade de Educação da Universidade de São Paulo, FEUSP, 2002.

- Descobrir as texturas da essência da terra: formação inicial de práxias criadora do professor de arte. 2007. (Doutorado em Educação) - Faculdade de Educação da Universidade de São Paulo, FEUSP, 2007. . Sobre arte e educação: entre a oficina artesanal e a sala de aula. Campinas: Papirus, 2010.

. Memória e reflexão: a biografia como metodologia de investigação e instrumento de (auto) formação de professores de arte. Disponível em: $<$ http://www.anpap.org.br/anais/2009/pdf/ceav/sumaya_mattar_moraes. pdf>. Acesso em 20.out.2018.

. O ato cartográfico na docência de arte: instraurando estados criativos de experimentação. Encontro Nacional da ANPAP, 26, Anais... Anpap: Campinas, 2017. Disponível em: < http://www.anpap.org.br>. Acesso em 21.nov.2018.

- O lugar do relato autobiográfico no sistema formativo cartografias de si. Revista Digital do LAV, Santa Maria: UFSM, v. 11, n. 2, p. 259-273, mai./ago.2018. Disponível em: <https://periodicos.ufsm.br/revislav/ article/view/33913/pdf>. Acesso em 28.out.2018.

MAGALHÃES, Ana Del Tabor Vasconcelos. Ensinar/aprender Arte no curso de Pedagogia: desafios e perspectivas na formação docente. In: Arte e Pedagogia a margem faz parte do Rio. São Paulo: Porto das ideias, 2017. MARCONDES, Mariana Machado. A criança é performer, 2010. Disponível em: $<$ https://seer.ufrgs.br/educacaoerealidade/article/view/11444/9447>.

MEDEIROS, Afonso. Arte e Pedagogia: o poder da imagem nas tensões filosóficas entre educação estética e a educação artística. In: Arte e Pedagogia a margem faz parte do Rio. São Paulo: Porto das ideias, 2017.

OSTETTO, Luciana Esmeralda. Educadores na roda da dança: formação-transformação. (Doutorado em Educação) - Universidade de Campinas, FE, 2006.

PELBART, Péter Pal. Estamos em guerra, 2017. Disponível em: < https://outraspa- lavras.net/desigualdades-mundo/peter-pal-pelbart-estamos-em-guerra/> PIETRO, Heloisa. Divinas Aventuras histórias da mitologia grega. São Paulo: Companhia das Letrinhas, 1997.

. Divinas Desventuras outras histórias da mitologia grega. São Paulo: Companhia das Letrinhas, 2009

Divinas Travessuras mais histórias da mitologia grega. São Paulo: Companhia das Letrinhas, 2012

PICON-VALLIN, Beatrice. Meierhold. São Paulo: Editora Perspectiva, 2013. ROSSETTO, Ana Cristina Rocha. Memória de Iniciação Artística e a Criação de Si. (Doutorado em Educação) - Universidade de Campinas, FE, 2017.

SAFATLE, Vladimir. Idiotas Úteis. Publicado no jornal: Folha de São Paulo, 17 maio 2019.

SUBCOMANDANTE, Marcos. A História das cores. São Paulo: Martins Fontes, 2003.

TESSLER, Elida Starosta. O museu é o mundo - arte e vida cotidiana na experiência de Hélio Oiticica. Rio de Janeiro: Azougue, 2012.

\section{VÍDEOS}

https://www.youtube.com/watch?v=3jlQgTHqtUM.

https://www.youtube.com/watch?v=ewM8J4IXfho\&feature=share.

\section{SITES PESQUISADOS}

http://www.flavioimperio.com.br/projeto/510007

http://www.mst.org.br/quem-somos/, em 10/4/2019

www.labarte.fe.usp.br

http://www.escolasempartido.org/o-papel-do-governo-categoria/539-dia-historico-projeto-de-lei-que-institui-o-programa-escola-sem-partido-e-apresentado-na-camara-dos-deputados. 

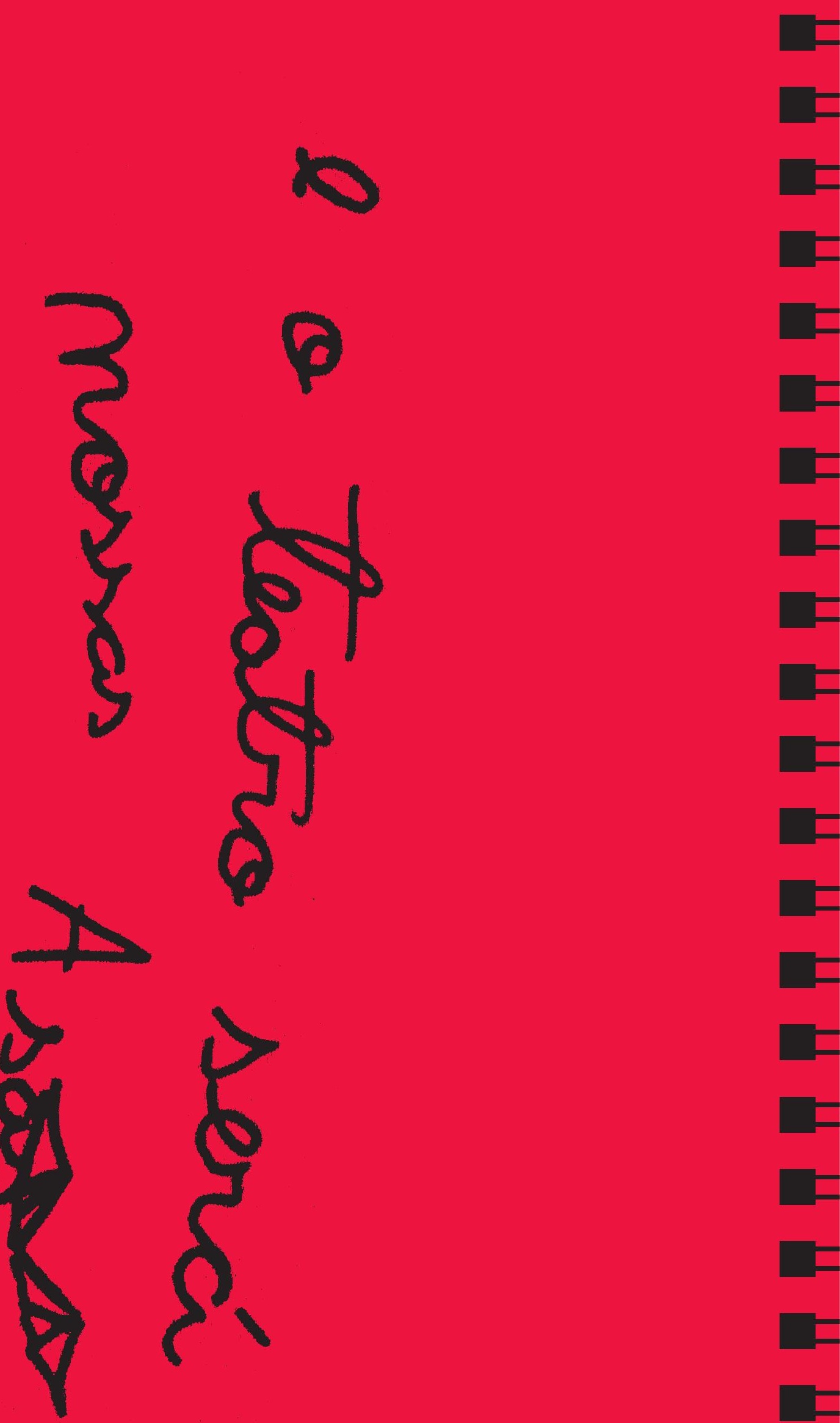

E 